SARAH LIA DE OLIVEIRA

\title{
Impacto na saúde, produção e qualidade do ovo de poedeiras alimentadas com cobre, manganês e zinco complexados com aminoácido
}

São Paulo

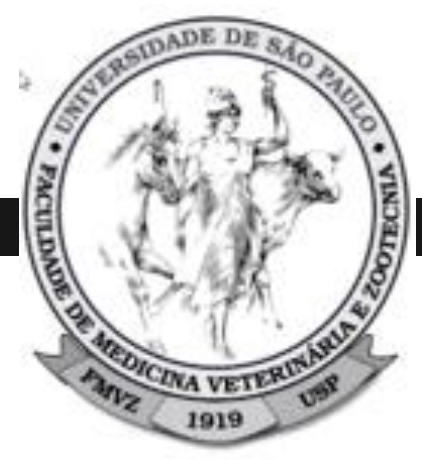




\section{Impacto na saúde, produção e qualidade do ovo de poedeiras alimentadas com cobre, manganês e zinco complexados com aminoácido}

Dissertação apresentada ao Programa de Pós-graduação em Clínica Veterinária da Faculdade de Medicina Veterinária e Zootecnia da Universidade de São Paulo para obtenção do título de Mestre em Ciências.

Programa de Pós-Graduação em Clínica Veterinária

Área de Concentração:

Clínica Veterinária

Orientadora:

Prof ${ }^{\text {a }}$. Drª . Maria Claudia Araripe Sucupira

São Paulo 2020 
Autorizo a reprodução parcial ou total desta obra, para fins acadêmicos, desde que citada a fonte.

\section{DADOS INTERNACIONAIS DE CATALOGAÇÃO NA PUBLICAÇÃO}

(Biblioteca Virginie Buff D'Ápice da Faculdade de Medicina Veterinária e Zootecnia da Universidade de Så Paulo)

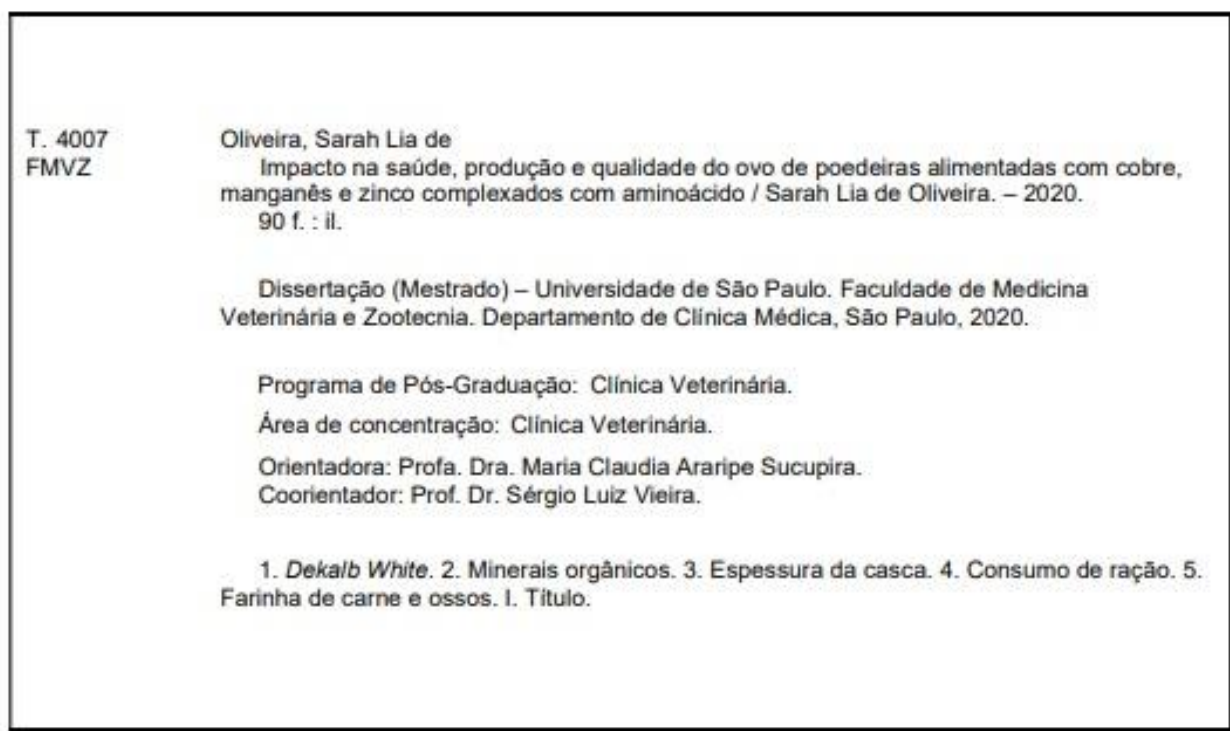

Ficha catalograffica elaborada pela biblotecária Maria Aparecida Laet, CRB 5673-8, da FMVZUSP 


\section{CERTIFICADO}

Certificamos que a proposta intitulada "Impacto na sabde, producto e qualidade do ovo de poedeiras alimentadas com cobre, mangandes e zinco complexados com aminoscido", protocobads sob a CEUA ne 6868180718 ab ockaz, sob a responsabilidade de Maria Claudia Araripe Sucupira e equipe; Sarah Lla de Orvelra - que ervelve a produça, manutençso efou utilizaça de animais pertencentes ao filo Chordata, subfib Vertebrata (exceto o homem), para fins de pesquisa cientifica ou ensino - ests de acordo com os preceitos da tel 12.794 de a de outubro de 200B, com o Decreto 6.899 de 15 de fulho de 2009, bem como com as normas editadas pelo Conselho Nacional de Controie da Experimentaça Animal ICONCEA), e foi aprovada pela Comissáo de Etica no Uso de Animais da Faculdade de Medicina Veterinaria e Zoctecnia da Universidade de Sso Paulo \{CEUAFNVZ\} na reuniso de $27,03 / 2019$

We certify that the proposal " Impact on health, egg quaity and probuction of laying hens fed with copoer, manganese and zinc complexed with amino acid", Utilizing 520 Birds (510 females], protocol number CEUA 6868180718 aD 66k212), under the responslbility of Maria Claudla Araripe Sucupira and teamy Sarah Lia de Criveira - Which involves the production, maintenance and/er use of animals belonging to the phylum Chordata, subphylum Vertebeata (except human beingsi), for scientific research purposes or tesching - is in accordance with Law 11.794 of October 8, 2008, Decree 6899 of July 15, 2009, as well as with the rules, issued by the National Counci for Control of Animal Experimentation (CONCEA), and was approved by the Ethic Committee on Animal Lse of the School of Veterinary Medicine and Animal Science (Unirersity of Saso Pada) (CEUA/FMVZ) in the meeting of $03 / 27 / 2019$.

Finalibade da Proposta: Resouisa

Wgência da Proposta: de 09/2013 a 07/2019 Area: Clinica Midica Veterinátia

Origem: Animais provenientes de estabeiccimentos cemerciais

$\begin{array}{lll}\text { Espécie: Aves } & \text { sewo: Fèmeas } & \text { idado: } 40 \text { a Bo scmanas N: } 510 \\ \text { Linhagem: a dofinir } & & \text { Peso: } 1400 \text { a } 1800 \mathrm{~g}\end{array}$

Local do expenimento: Centro de Pesquisa em Nutricta e Doenças Nutricionais de Aves

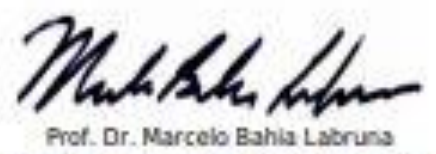

Coordensdor da Comissta de Etica no Uso de Animss

Faculdade de Medicina Veterindria e Zooteconia da Universidade de Sio Paulo

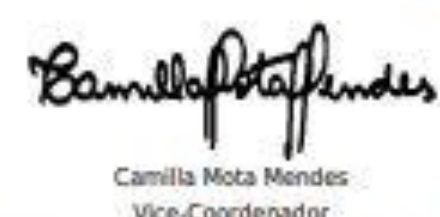

Vice-Coordenador

Faculdade de Medicina Veterinária e Zootecnia da Universidade de 5 so Paila

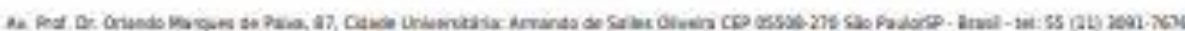

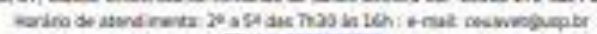

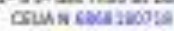




\section{FOLHA DE AVALIAÇÃO}

Autor: OLIVEIRA, Sarah Lia

Título: Impacto na saúde, produção e qualidade do ovo de poedeiras alimentadas com cobre, manganês e zinco complexados com aminoácido

Dissertação apresentada ao Programa de Pós-graduação em Clínica Veterinária da Faculdade de Medicina Veterinária e Zootecnia da Universidade de São Paulo para obtenção do título de Mestre em

Ciências.

Data:

Banca Examinadora

Prof. Dr.

Instituição: Julgamento:

Prof. Dr.

Instituição: Julgamento:

Prof. Dr. Instituição: Julgamento: 
Dedico aos meus pais e irmã que sempre me apoiaram, ajudaram e me permitiram sonhar. 


\section{AGRADECIMENTOS}

Aos meus pais Mauricio e Brigitte e minha irmã Jessica Lia, pela estrutura familiar que me permitiu trilhar este caminho, por torcerem pelo meu sucesso, pelos conselhos, ajudas nos plantões e por estarem sempre ao meu lado.

À profa. Dra. Maria Claudia Araripe Sucupira, pela orientação, parceria, companheirismo, dedicação, paciência, prontidão, que aceitou enfrentar esse desafio ao meu lado e se tornou grande exemplo e inspiração.

Ao Sr Abelardo de Souza (Dinho) e Agnaildo, pela paciência, ajuda e ensinamentos que só pessoas com tantos anos de experiência saberiam transmitir com tanta maestria.

À Clara Mori, por toda monitoria e ensinamentos laboratoriais e parceria com o projeto.

Aos ICs Lucas, Rodrigo, Mario, Luca e Raquel, pela dedicação, interesse e companhia.

Aos colegas do PcVet José Ferronatto, Carol dos Anjos, Fábio Teixeira, Telma Strauss, Kamila Reis, Miriam Zibordi, Vinicius Vasques, Ronaldo Gargano e residentes do hospital ruminantes Natali Schllemer, Alyne Kaaren e Thais Cristiane por me ajudarem nas coletas dos dados e companhia.

A Professora Cristiane Araujo por emprestar o equipamento EggTester ${ }^{\circledR}$ DET6000.

Ao Guilherme Sene e Professor Paulo Mazza, pelas aulas de estatística.

A empresa Zinpro pelo patrocínio e fornecimento dos minerais utilizados no projeto.

Ao Conselho Nacional de Desenvolvimento Científico e Tecnológico (CNPq) pela concessão da bolsa de mestrado, que possibilitou dedicação exclusiva ao projeto e ao mestrado. 
À Coordenação de Aperfeiçoamento de Pessoal de Nível Superior - Brasil (CAPES), pelo apoio à pós-graduação e viabilizar praticamente todos os programas de pós-graduação do país.

À Universidade de São Paulo, por fornecer a infraestrutura e oportunidade de concretizar o projeto.

E a todas as aves utilizadas durante o período de estudo pela colaboração, aprendizado e companhia. 


\section{RESUMO}

OLIVEIRA, S.L. Impacto na saúde, produção e qualidade do ovo de poedeiras alimentadas com cobre, manganês e zinco complexados com aminoácido. 2020. Dissertação (Mestrado em Ciências) - Faculdade de Medicina Veterinária e Zootecnia, Universidade de São Paulo, São Paulo, 2020.

Para observar o impacto no desempenho produtivo, saúde animal e na qualidade interna e externa dos ovos com o uso de fontes de cobre, zinco e manganês orgânicos e da utilização da farinha de carne e ossos como fonte parcial de proteína na dieta de poedeiras em fase final de produção, foram utilizadas 480 poedeiras da linhagem Dekalb White, com idade inicial de 55 semanas. O delineamento experimental foi de blocos casualizados com planejamento fatorial $5 \times 2$, contemplando todas as combinações minerais e proteicas propostas. Dessa forma as aves foram distribuídas em dez tratamentos e foram acompanhadas durante 42 semanas. Os resultados do estudo mostraram queda no consumo de ração do tratamento 7 (zinco orgânico e farelo de soja como única fonte proteica), nos dias 0 e 60 ( $P=0,0425$ e $P<0,001$, respectivamente), no dia 60 este mesmo tratamento obteve ovos mais leves e CA por dúzia maior em relação aos outros tratamentos. Já nos períodos de 240 e 300 dias, a CA por dúzia foi melhor no tratamento com todos os elementos sob a forma inorgânica em contraposto ao orgânico, independente da fonte proteica. Poedeiras alimentadas com farelo de soja, em comparação às alimentados com farinha de carne e ossos obtiveram, ovos mais pesados $(P=0,0166)$, com maior densidade $(P=0,0415)$, maiores valores para unidade Haugh $(P=0,0404)$, maior altura do albúmen $(P=0,0240)$ e cor de gema mais clara $(P=0,0017)$. Os dados de espessura, porcentagem e resistência da casca, classificação do ovo, ovoscopia, peso das poedeiras, densitometria óssea e atividade da SOD não foram influenciados pela fonte mineral ou proteica. Esses resultados indicam que não foi observado efeito nos parâmetros analisados com o uso de 7 ppm de cobre, 40 ppm de zinco e 40 ppm de manganês complexados com aminoácidos (orgânicos), em poedeiras a partir da 55a semana de vida, e o uso de 4\% de farinha de carne e ossos não foi benéfico para alguns indicadores da qualidade do ovo, como unidade Haugh, altura do albúmen, peso do ovo e densidade quando comparado com o uso exclusivo de farelo de soja como fonte proteica. 
Palavras-chave: Dekalb White. Minerais orgânicos. Espessura da casca. Consumo de ração. Farinha de carne e ossos. 


\section{ABSTRACT}

OLIVEIRA, S.L. Impact on health, production and egg quality of laying hens fed with copper, manganese and zinc complexed with amino acid. 2020. Dissertação (Mestrado em Ciências) - Faculdade de Medicina Veterinária e Zootecnia, Universidade de São Paulo, São Paulo, 2020.

To observe the impact on productive performance, animal health and egg quality with the use of sources of organic copper, zinc and manganese and the use of meat and bone meal as a partial source of protein in the diet of laying hens in the final stage of production , 480 laying hens of the Dekalb White lineage were used, with an initial age of 55 weeks. The experimental design was randomized blocks with a $5 \times 2$ factorial design, covering all proposed mineral and protein combinations. In this way, the birds were distributed in ten treatments and were followed for 42 weeks. The results of the study showed a drop in feed intake of treatment 7 (soy and complexed zinc), on days 0 and $60(P=0.0425$ and $P$ $<0.001$, respectively), on day 60 this same treatment obtained lighter eggs and higher FCR per dozen higher than other treatments. In the periods of 240 and 300 days, FCR per dozen was better in the inorganic treatment as opposed to the organic one. Layers fed with soybean meal, compared to those fed with meat and bone meal obtained, in general, higher egg weight $(P=0.0166)$, egg density $(P=0.0415)$, Haugh unit $(P=0.0404)$, height of albumen $(P=0.0240)$ and lighter yolk color $(P=0.0017)$. The data of thickness, percentage and resistance of the shell, egg classification, ovoscopy, laying weight, bone densitometry and SOD activity were not influenced by the mineral or protein source. These results indicate that there was no effect on the parameters analyzed with the use of 7 ppm of copper, 40 ppm of zinc and 40 ppm of manganese complexed with amino acids (organic), in layers from the 55th week of life onwards, and the use of $4 \%$ meat and bone meal was not beneficial for some indicators of egg quality, such as Haugh unit, albumen height, egg weight and density when compared to the exclusive use of soybean meal as a protein source.

Keywords: Dekalb White. Organic minerals. Shell thickness. Feed Intake. Meat and bone meal. 


\section{LISTA DE FIGURAS E GRÁFICOS}

Figura 1 Poedeira Dekalb White com 55 semanas de vida selecionada para o estudo. São Paulo - 2020. 36

Figura 2 Aves com 55 dias de idade alojadas nas 240 gaiolas experimentais. São Paulo - 2020 .

Figura 3 Misturador tipo horizontal helicoidal utilizado para ingredientes de maior escala. São Paulo - 2020.

Figura 4 Misturador tipo Y utilizado para inclusão dos premixes nas rações.

São Paulo - 2020. 38

Figura 5 Galpão organizado com o auxílio de baldes identificados por gaiola. São Paulo - 2020

Figura 6 Pesagem do ovo. São Paulo-2020. .41

Figura 7 Determinação da gravidade específica do ovo. São Paulo 2020 .

Figura 8 Determinação eletrônica da unidade Haugh por meio do aparelho EggTester ${ }^{\circledR}$ DET6000. São Paulo - 2020.

Figura 9 Determinação da cor da gema com Yolk Colour Fan. São Paulo 2020 . .43

Figura 10 Espessura de casca com micrômetro digital Ames ${ }^{\circledast}$ 25M-5. São Paulo - 2020 44

Figura 11 Determinação eletrônica da resistência da casca com o aparelho EggTester ${ }^{\circledR}$ DET6000. São Paulo - 2020.

Figura 12 Ovoscopia em câmara escura. São Paulo - 2020..........................46

Figura 13 Radiografia das tíbias de ave com penetrômetro. São Paulo 2020 
Gráfico 1 Interação do consumo de ração (g/ave) entre proteína e mineral na coleta 1 (0 dias) em poedeiras Dekalb White. São Paulo, 2020 .

Gráfico 2 Interação do consumo de ração (g/ave) entre proteína e mineral na coleta 2 (60 dias) em poedeiras Dekalb White. São Paulo, 2020 52

Gráfico 3 Interação do consumo de ração médio (g/ave) entre proteína e mineral, durante todo o período experimental em poedeiras Dekalb White. São Paulo, 2020

Gráfico 4 Interação da conversão alimentar por dúzia entre proteína e mineral na coleta 1 (0 dias) em poedeiras Dekalb White. São Paulo, 2020 . .55

Gráfico 5 Interação da conversão alimentar por dúzia entre proteína e mineral na coleta 2 (60 dias) em poedeiras Dekalb White. São Paulo, 2020 56

Gráfico 6 Interação do peso dos ovos (g) entre proteína e mineral na coleta 2 (60 dias) em poedeiras Dekalb White. São Paulo, 2020.

Gráfico 7 Valores médios para a densitometria óssea realizada nas tíbias direitas de poedeiras Dekalb White, que receberam $4 \%$ de farinha de carne e ossos (FCO) em substituição parcial ao farelo de soja e os elementos zinco, manganês e cobre, isoladamente e/ou associados na forma orgânica durante 40 semanas. São Paulo, 2020 69 


\section{LISTA DE QUADROS E TABELAS}

Quadro 1 Distribuição dos tratamentos experimentais para avaliar o impacto do uso de fontes de zinco, manganês e cobre isolados ou associados na forma orgânica e a farinha de carne e ossos na dieta de poedeiras Dekalb White com idade inicial de 55 semanas. São Paulo, 2020. 38

Tabela 1 Composição das dietas experimentais. São Paulo, 2020. .39

Tabela 2 Composição das rações oferecidas para as poedeiras durante 0 período experimental, considerando matéria seca (MS), matéria mineral $(\mathrm{MM})$, proteína bruta $(\mathrm{PB})$ e fósforo $(\mathrm{P})$. São Paulo, 2020 . 49

Tabela 3 Média da temperatura no interior do galpão experimental. São Paulo, 2020. .50

Tabela 4 Consumo médio de ração por ave por semana (g/ave/semana) em poedeiras Dekalb White, com idade inicial de 55 semanas que receberam $4 \%$ de farelo de carne e ossos (FCO) em substituição parcial ao farelo de soja e os elementos zinco, manganês e cobre isoladamente e associados na forma orgânica durante 42 semanas. São Paulo, 2020

Tabela 5 Produção média de ovos por ave por semana em poedeiras Dekalb White, com idade inicial de 55 semanas que receberam $4 \%$ de farelo de carne e ossos (FCO) em substituição parcial ao farelo de soja e os elementos zinco, manganês e cobre isoladamente e associados na forma orgânica durante 42 semanas. São Paulo, 2020 .54

Tabela 6 Conversão alimentar por dúzia de ovos produzida em poedeiras Dekalb White, com idade inicial de 55 semanas que receberam 4\% de farelo de carne e ossos (FCO) em substituição parcial ao farelo de soja e os elementos zinco, manganês e cobre isoladamente e associados na forma orgânica durante 42 semanas. São Paulo, 2020 .55 
Tabela 7 Peso dos ovos (g) em poedeiras Dekalb White, com idade inicial de 55 semanas que receberam $4 \%$ de farelo de carne e ossos (FCO) em substituição parcial ao farelo de soja e os elementos zinco, manganês e cobre isoladamente e associados na forma orgânica durante 42 semanas. São Paulo, 2020

Tabela 8 Gravidade específica dos ovos $\left(\mathrm{g} / \mathrm{cm}^{3}\right)$ em poedeiras Dekalb White, com idade inicial de 55 semanas que receberam $4 \%$ de farelo de carne e ossos (FCO) em substituição parcial ao farelo de soja e os elementos zinco, manganês e cobre isoladamente e associados na forma orgânica durante 42 semanas. São Paulo, 2020. .58

Tabela 9 Unidade Haugh dos ovos mensurada por meio do EggTester ${ }^{\circledast}$ DET6000, nos ovos produzidos por poedeiras Dekalb White, com idade inicial de 55 semanas que receberam $4 \%$ de farelo de carne e ossos (FCO) em substituição parcial ao farelo de soja e os elementos zinco, manganês e cobre isoladamente e associados na forma orgânica durante 42 semanas. São Paulo, 2020

Tabela 10 Valores para a altura do albúmen dos ovos $(\mathrm{mm})$, mensurados por meio do EggTester ${ }^{\circledR}$ DET6000, nos ovos produzidos por poedeiras Dekalb White, com idade inicial de 55 semanas que receberam 4\% de farelo de carne e ossos (FCO) em substituição parcial ao farelo de soja e os elementos zinco, manganês e cobre isoladamente e associados na forma orgânica durante 42 semanas. São Paulo, 2020 .60

Tabela 11 Cor da gema mensurada por meio do Youlk Colour Fan nos ovos produzidos por poedeiras Dekalb White, com idade inicial de 55 semanas que receberam $4 \%$ de farelo de carne e ossos (FCO) em substituição parcial ao farelo de soja e os elementos zinco, manganês e cobre isoladamente e associados na forma orgânica durante 42 semanas. São Paulo, 2020

Tabela 12 Cor da gema mensurada por meio do EggTester® DET6000 nos ovos produzidos por poedeiras Dekalb White, com idade inicial de 55 semanas que receberam $4 \%$ de farelo de carne e ossos (FCO) 
em substituição parcial ao farelo de soja e os elementos zinco, manganês e cobre isoladamente e associados na forma orgânica durante 42 semanas. São Paulo, 2020

Tabela 13 Espessura da casca dos ovos $(\mathrm{mm})$ dos ovos produzidos por poedeiras Dekalb White, com idade inicial de 55 semanas que receberam $4 \%$ de farelo de carne e ossos (FCO) em substituição parcial ao farelo de soja e os elementos zinco, manganês e cobre isoladamente e associados na forma orgânica durante 42 semanas. São Paulo, 2020

Tabela 14 Porcentagem de casca (\%) nos ovos produzidos por poedeiras Dekalb White, com idade inicial de 55 semanas que receberam $4 \%$ de farelo de carne e ossos (FCO) em substituição parcial ao farelo de soja e os elementos zinco, manganês e cobre isoladamente e associados na forma orgânica durante 42 semanas. São Paulo, 2020

Tabela 15 Valores médios para resistência da casca $(\mathrm{kfg})$, mensurados por meio EggTester ${ }^{\circledR}$ DET6000, dos ovos produzidos por poedeiras Dekalb White, com idade inicial de 55 semanas que receberam $4 \%$ de farelo de carne e ossos (FCO) em substituição parcial ao farelo de soja e os elementos zinco, manganês e cobre isoladamente e associados na forma orgânica durante 42 semanas. São Paulo, 2020 .64

Tabela 16 Valores médios para a classificação dos ovos, mensurados por meio do EggTester® DET6000, produzidos por poedeiras Dekalb White, com idade inicial de 55 semanas que receberam $4 \%$ de farelo de carne e ossos (FCO) em substituição parcial ao farelo de soja e os elementos zinco, manganês e cobre isoladamente e associados na forma orgânica durante 42 semanas. São Paulo, 2020 .65

Tabela 17 Valores médios para a ovoscopia, por meio de câmera escura com a incidência de feixe de luz, nos ovos produzidos por poedeiras Dekalb White, com idade inicial de 55 semanas que receberam $4 \%$ 
de farelo de carne e ossos (FCO) em substituição parcial ao farelo de soja e os elementos zinco, manganês e cobre isoladamente e associados na forma orgânica durante 42 semanas. São Paulo, 2020 66

Tabela 18 Valores médios para o peso das poedeiras $(\mathrm{kg})$ Dekalb White, com idade inicial de 55 semanas que receberam $4 \%$ de farelo de carne e ossos (FCO) em substituição parcial ao farelo de soja e os elementos zinco, manganês e cobre isoladamente e associados na forma orgânica durante 42 semanas. São Paulo, 2020.

Tabela 19 Valores médios para a atividade da enzima superóxido dismutase $(\mathrm{U} / \mathrm{ml})$ em poedeiras Dekalb White, com idade inicial de 55 semanas que receberam $4 \%$ de farelo de carne e ossos (FCO) em substituição parcial ao farelo de soja e os elementos zinco, manganês e cobre isoladamente e associados na forma orgânica durante 42 semanas. São Paulo, 2020 ........................................68 


\begin{tabular}{|c|c|}
\hline$<$ & menor \\
\hline$>$ & maior \\
\hline$\%$ & porcentagem \\
\hline${ }^{\circ} \mathrm{C}$ & graus celsius \\
\hline $\mathrm{CA}$ & conversão alimentar \\
\hline $\mathrm{cm}^{3}$ & centímetro cúbico \\
\hline $\mathrm{Cu}$ & cobre \\
\hline g & grama \\
\hline Inorg & inorgânico \\
\hline $\mathrm{kg}$ & quilograma \\
\hline $\mathrm{Mn}$ & manganês \\
\hline Org & orgânico \\
\hline $\mathrm{T} 1$ & tratamento 1 \\
\hline $\mathrm{T} 2$ & tratamento 2 \\
\hline T3 & tratamento 3 \\
\hline T4 & tratamento 4 \\
\hline T5 & tratamento 5 \\
\hline T6 & tratamento 6 \\
\hline T7 & tratamento 7 \\
\hline T8 & tratamento 8 \\
\hline T9 & tratamento 9 \\
\hline T10 & tratamento 10 \\
\hline $\mathrm{Zn}$ & zinco \\
\hline
\end{tabular}




\section{SUMÁRIO}

1 INTRODUÇÃO...................................................................................21

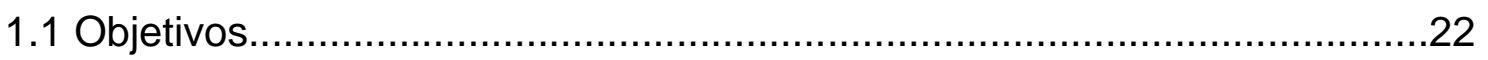

2 REVISÃO DE LITERATURA..............................................................23

2.1 Importância da suplementação mineral.....................................................23

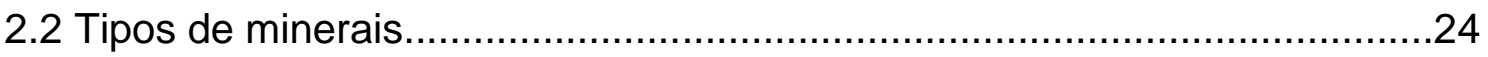

2.2.1 Benefícios dos minerais orgânicos.................................................25

2.2.2 Importancia da qualidade da casca do ovo para a industria....................26

2.2.3 Microminerais e a qualidade ossea em poedeiras em fase de produção....27

2.2.4 Suplementação de manganês orgânico em poedeiras...........................29

2.2.5 Suplementação de zinco orgânico em poedeiras...................................31

2.2.6 Suplementação de cobre orgânico em poedeiras....................................32

2.2.7 Uso de farinha de carne e ossos na alimentação de poedeiras..................33

3 MATERIAL E MÉTODOS...........................................................................35

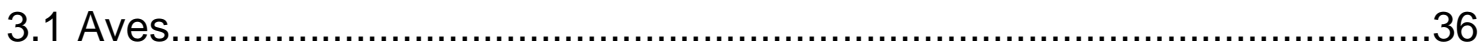

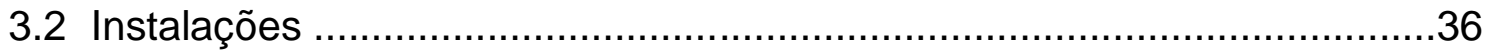

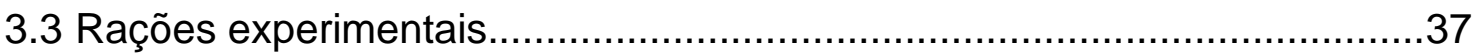

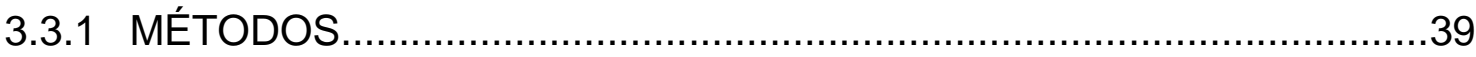

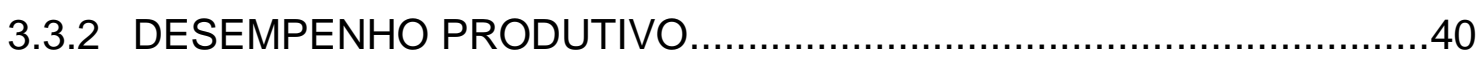

3.3.2.1 Consumo de ração........................................................40

3.3.2.2 Produção de ovos por ave por semana......................................40

3.3.2.3 Conversão alimentar por dúzia................................................41

3.3.2.4 Peso dos ovos.......................................................................... 41

3.3.3 QUALIDADE INTERNA E EXTERNA DO OVO.................................41

3.3.3.1 Gravidade específica....................................................... 42

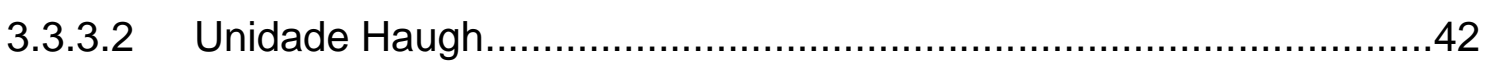

3.3.3.3 Altura do albúmen...........................................................43

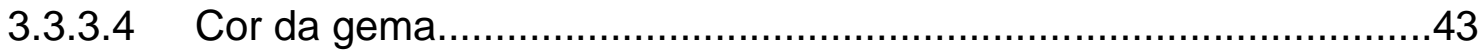

3.3.3.5 Espessura da casca...........................................................43

3.3.3.6 Porcentagem de casca......................................................44

3.3.3.7 Resistência de casca................................................................ 44

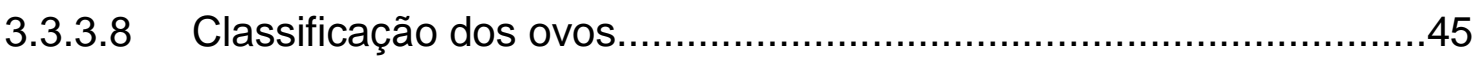

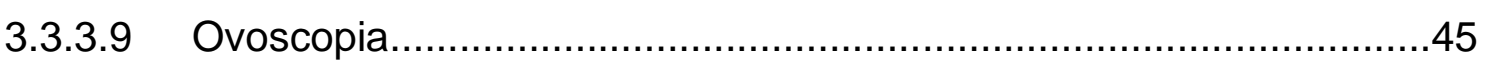




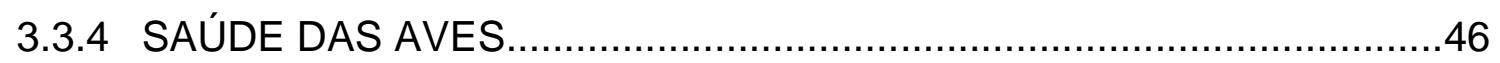

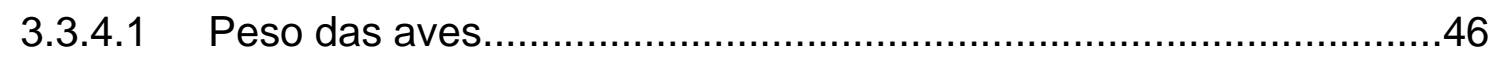

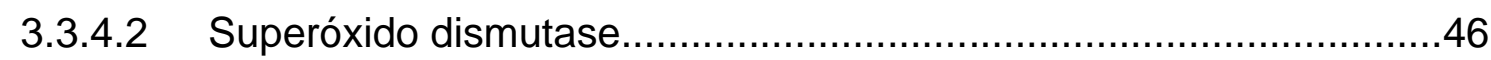

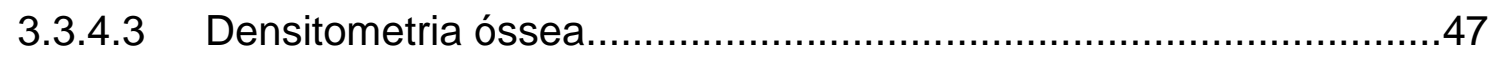

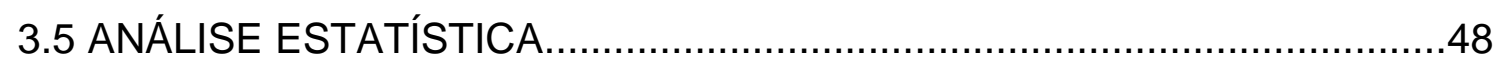

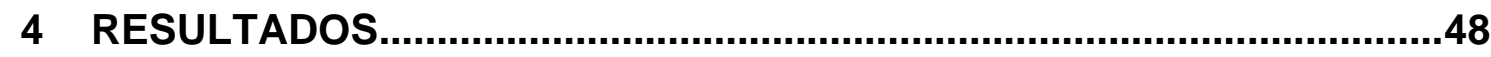

4.1 ANÁLISE BROMATOLÓGICA E TEMPERATURA DO GALPÃO...............48

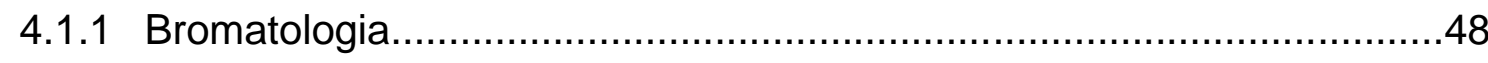

4.1.2 Temperatura............................................................................. 50

4.2 RESULTADOS DO DESEMPENHO PRODUTIVO......................................50

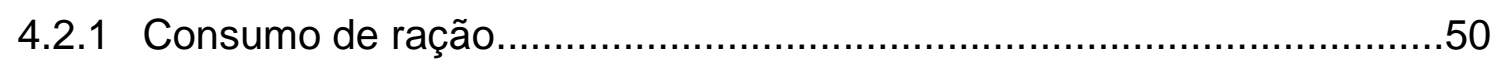

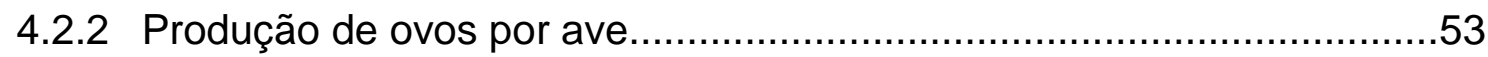

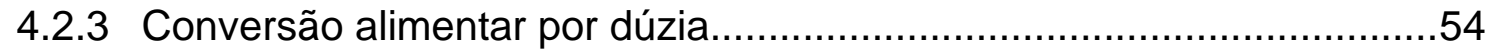

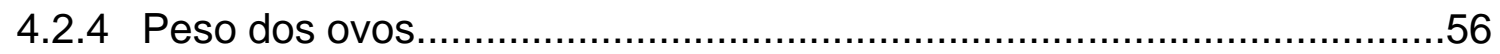

4.3 RESULTADO DA QUALIDADE INTERNA E EXTERNA DO OVO..............58

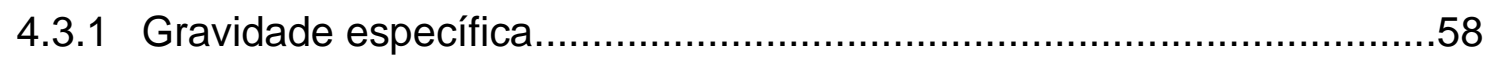

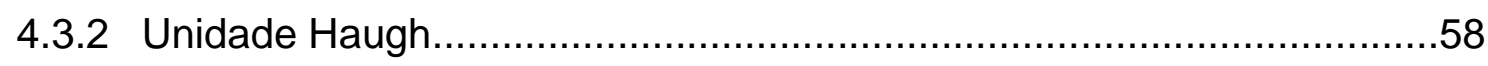

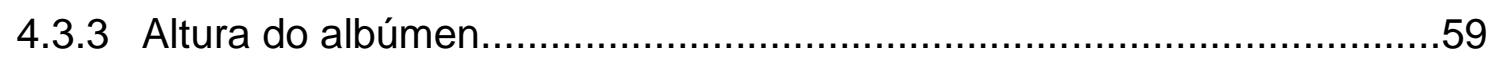

4.3.4 Cor da gema

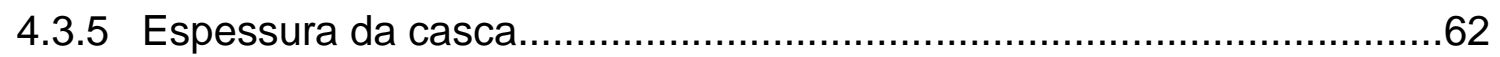

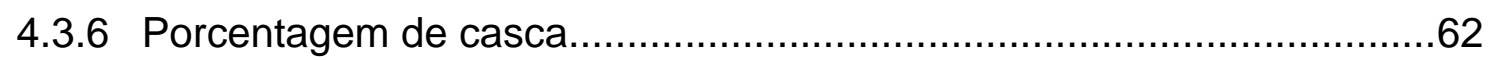

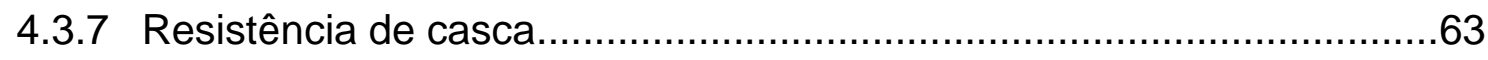

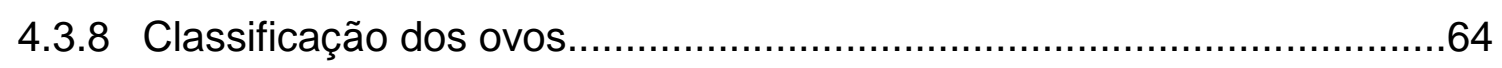

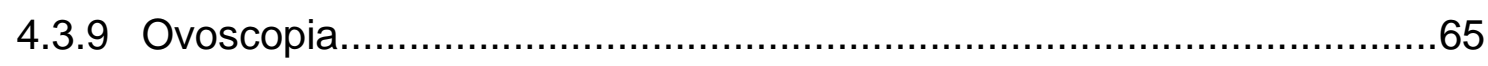

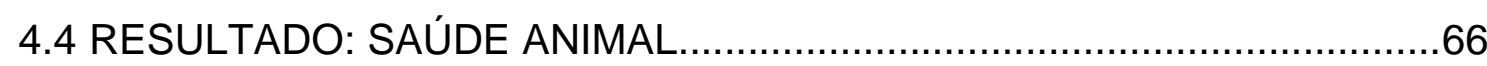

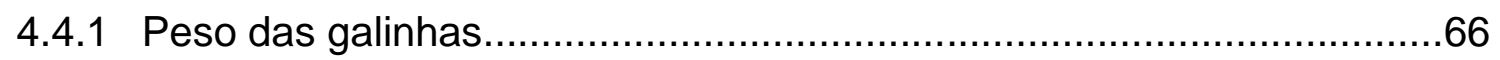

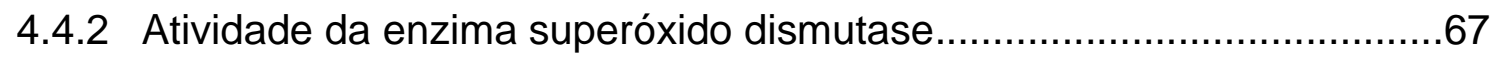

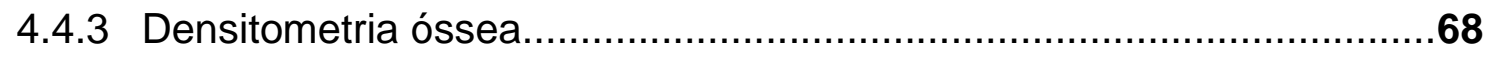

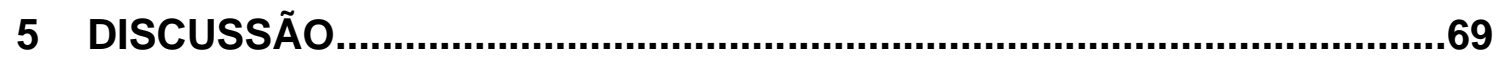

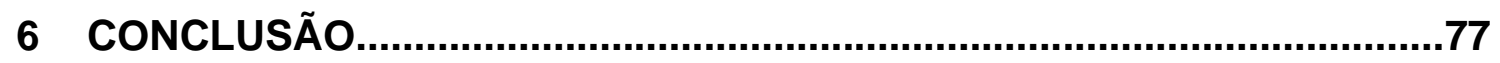

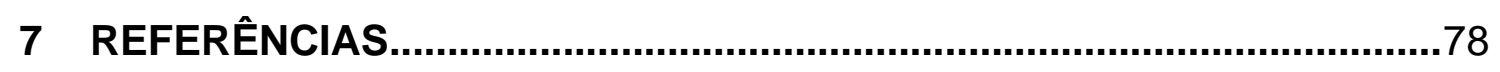




\section{INTRODUÇÃO}

O Brasil está entre os dez maiores produtores mundiais de ovos. De acordo com dados do IBGE, a produção de ovos de galinha foi de 3,83 bilhões de dúzias em 2019, representando aumento de 6,3\% em relação ao ano anterior. Também em 2019 o consumo per capita de ovos entre os brasileiros saltou para 230, ante os 212 ovos consumidos per capita em 2018. Esses dados mostram a grande importância do setor avícola, que busca constantemente soluções para alguns gargalos, como otimização da eficiência de alimentação e melhor qualidade dos ovos e, principalmente da sua casca, que representa parcela importante de perda econômica na fase de produção, visto que milhões de ovos deixam de ser comercializados ou têm seus preços reduzidos em função de problemas na casca. O desenvolvimento da avicultura brasileira deve-se a uma associação entre genética, nutrição, manejo e sanidade, aliados à facilidade com que o setor adota as novas tecnologias e busca melhorar a eficiência em termos produtivos e econômicos beneficiando-se do potencial genético das atuais linhagens de poedeiras.

Dentre os gastos descritos para manter uma granja de postura, é notório que a maior porcentagem é decorrente dos custos com a nutrição dos animais. Observar a qualidade da nutrição das aves faz com que seja possível entregar ao consumidor final um produto melhor, além de tornar o negócio mais rentável por meio da otimização nutricional, evitando desperdícios. A incorporação de núcleos completos com vitaminas, minerais e outros suplementos é uma estratégia cada vez mais estudada, pois ajuda a ave expressar seu potencial genético. Nesse contexto, os minerais têm grande destaque para poedeiras, devido ao uso de gaiolas, que impossibilitam o contato da ave com a terra, considerada importante fonte de minerais; e por ser uma possível opção para amenizar os gargalos do setor, como a má qualidade da casca do ovo. É reconhecido que os teores ajustados de minerais na nutrição de poedeiras estão diretamente relacionados à qualidade da casca dos ovos, refletindo no número de ovos trincados e consequentemente comercializados.

Outro ponto a ser considerado é a longevidade das galinhas. Com o aperfeiçoamento das linhagens o setor avícola conseguiu prolongar a vida útil das poedeiras, possibilitando, em alguns casos, produção satisfatória por até 
mais de cem semanas de vida. Porém, à medida que as aves envelhecem há menor eficiência de absorção dos nutrientes pelo trato digestório, assim como também pode ocorrer menor aproveitamento dos nutrientes absorvidos. Em contrapartida o peso do ovo aumenta, sem, contudo, aumentar a deposição de cálcio na casca, sendo produzidos ovos maiores e de casca fina, consequentemente a qualidade interna e externa do ovo se alteram de forma prejudicial. Assim se tornam ainda mais necessários estudos que contemplem nutrientes capazes de interferir positivamente na saúde da poedeira e qualidade do ovo tentando minimizar o impacto da idade.

Nesse sentido, há pesquisas sobre a substituição de minerais inorgânicos por orgânicos na nutrição das aves, porém, os benefícios dessa substituição ainda são controversos.

Outro alimento com grande potencial para ser utilizado nas dietas de poedeiras é a farinha de carne e ossos, considerada boa fonte de aminoácidos, minerais, vitaminas e, quando bem processada, principalmente de fósforo. Porém, por se tratar de produto orgânico, é altamente susceptível a contaminações. A falta de padrão de qualidade ou mesmo de alguns cuidados sanitários durante seu processamento, bem como a potencial baixa digestibilidade, torna o uso da farinha de carne e ossos uma questão a ser estudada.

\subsection{OBJETIVOS}

O objetivo desse estudo foi avaliar o efeito tanto do uso de fontes orgânicas de $\mathrm{Zn}, \mathrm{Mn}$ e $\mathrm{Cu}$ oferecidas isoladamente ou associadas em associação com a inclusão de $4 \%$ de farinha de carne e ossos como substituto parcial do farelo de soja, da $55^{\mathrm{a}}$ até a $97^{\mathrm{a}}$ semanas de vida da poedeira, analisando aspectos da saúde da ave, qualidade óssea, dados de produção e qualidade do ovo. 


\section{REVISÃO DE LITERATURA}

A seguir serão abordados os tópicos mais relevantes obtidos na literatura revisada.

\subsection{IMPORTÂNCIA DA SUPLEMENTAÇÃO MINERAL}

Os primeiros estudos sobre fontes de minerais para rações datam da década de 50 , quando se iniciou a suplementação mineral para resolver problemas ósseos e de desempenho de aves (ARAUJO et al., 2008). A importância da suplementação mineral para aves aumentou nos últimos anos devido a uma série de fatores relacionados à produção desses animais como o melhoramento genético, resultando em animais mais leves, com maior produção de ovos e persistência de postura; melhor conversão alimentar; menor consumo de ração; e maturidade sexual precoce (COSTA et al., 2015).

Outros fatores que complementam essa lista, são o modelo de criação em confinamento, retirando a possibilidade de contato direto com a terra, que é importante fonte de minerais; a retirada ou redução do uso de farinhas de origem animal nas rações devido a possíveis problemas com a transmissão de doenças, mesmo que essas farinhas sejam fontes de minerais, inclusive na forma orgânica; e rações à base de ingredientes vegetais, que geralmente têm menor disponibilidade de minerais (ARAUJO et al., 2008).

Deve-se considerar também que o uso de rações com maior densidade de nutrientes, cada vez mais recomendada na criação intensiva, normalmente leva à maior excreção destes, inclusive de minerais no ambiente (BERTECHINI, 2006). Assim, todos esses fatores colaboraram para o aumento nos cuidados com o fornecimento do suplemento mineral para tornar a nutrição das aves cada vez mais adequada às exigências, pois deficiência ou excesso prejudicam o máximo desenvolvimento das aves (ALVES, 2002).

O conteúdo mineral das matérias primas de origem vegetal depende de vários fatores, como solo, clima, espécie explorada e sua maturidade (VEIGA \& CARDOSO, 2005). Embora compondo apenas cerca de 5\% do corpo de um animal, os minerais contribuem com grande parte do esqueleto ( $80 \%$ a $85 \%$ ), além de estarem presentes na formação da casca dos ovos e na estrutura dos 
músculos, metaloenzimas e metaloproteínas, sendo indispensáveis ao bom funcionamento do organismo (MCDOWELL, 1992 e BRITO et al., 2006).

\subsection{TIPOS DE MINERAIS}

Os minerais podem ser oferecidos na forma inorgânica ou na forma orgânica. Frequentemente, os nutricionistas utilizam minerais na forma inorgânica, buscando atender às exigências das aves. Ao alcançarem o trato gastrointestinal esses sais devem ser inicialmente solubilizados para liberarem íons e serem então absorvidos (ARAUJO et al., 2008). No entanto, quando na forma iônica os minerais podem se complexar com outros componentes da dieta, dificultando a absorção ou tornando-os indisponíveis aos animais. Tendo em vista estas incertezas, os teores de minerais fornecidos nas dietas são frequentemente superiores aos mínimos exigidos para otimizar o desempenho, resultando em excesso de fornecimento (RUTZ, et al. 2007a).

Nesse contexto cresce a importância do uso dos minerais orgânicos, que podem ser classificados, de acordo com a Association of American Feed Control Officials (AAFCO, 2009), em cinco formas:

a. Os complexos metal-aminoácidos, que são os produtos resultantes da reação de um sal metálico solúvel com aminoácidos;

b. os complexos metais-aminoácido específicos, que são o produto resultante da reação de um sal metálico solúvel com um aminoácido específico;

c. os quelatos metal-aminoácido, que são os produtos resultantes da reação de um sal metálico solúvel com aminoácidos na proporção molar, isto é, um mol do metal para um a três moles (preferencialmente dois) de aminoácidos na forma de ligação covalente coordenada;

d. os complexos metal-polissacarídeos, que são os produtos resultantes da complexação de um sal solúvel com um polissacarídeo; e 
e. os metais proteinados, que são associações de um sal solúvel com uma proteína parcialmente hidrolisada.

O valor biológico dos minerais pode aumentar bastante quando os elementos, que em sua maior parte são microelementos, são administrados na forma de complexo orgânico ou de quelatos, proteinados ou ainda de polissacarídeos (VEIGA \& CARDOSO, 2005).

\subsubsection{BENEFÍCIOS DOS MINERAIS ORGÂNICOS}

Tendo-se em vista as perspectivas de maior biodisponibilidade em relação às fontes inorgânicas convencionais, os microelementos sob a forma de complexo orgânico têm sido pesquisados e são considerados excelente alternativa para o aprimoramento nutricional de aves (REDDY, et al. 1992).

$\mathrm{Na}$ forma orgânica, os minerais são absorvidos pelos carreadores intestinais de aminoácidos e peptídeos e não por transportadores intestinais clássicos de minerais o que evita a competição entre esses elementos pelos mesmos mecanismos de absorção (RUTZ, et al. 2007a).

Considera-se que não só a biodisponibilidade seja superior, mas os minerais na forma orgânica são prontamente transportados para os tecidos, onde permanecem armazenados por períodos mais longos que os inorgânicos (RUTZ, et al. 2007a).

Segundo Polli, (2002), cada vez mais são desenvolvidas pesquisas para que estes nutrientes sejam mais bem aproveitados e desempenhem seu papel fisiológico adequadamente, resultando em animais cada vez mais saudáveis. $O$ benefício do uso de minerais orgânicos além de proporcionarem melhora no desempenho e vida útil das aves, também impacta na redução da excreção fecal dos microminerais pelos animais, o que é risco potencial ao meio ambiente (BRITO et al., 2006). Os minerais orgânicos têm assumido papel cada vez mais importante na nutrição animal, e a sua escolha, apesar de apresentarem maior custo inicial, principalmente frente aos minerais inorgânicos, pode significar 
economia e vantagens quando se pesa a relação custo/benefício (LEESON \& SUMMERS, 2005).

Apesar de encontrar facilmente os benefícios no uso de minerais orgânicos na literatura, muitas pesquisas demonstraram na prática que não há diferença entre minerais orgânicos e inorgânicos em termos de produção e qualidade do ovo, como o estudo conduzido por Sechinato, et al. (2006), que realizaram um trabalho como objetivo avaliar índices de produtividade de poedeiras comerciais recebendo suplementação com fontes orgânicas e inorgânicas de zinco, cobre, manganês, selênio, ferro e iodo. Os autores concluíram que o uso de formas orgânicas dos minerais: Mn, Zn, I, Se, $\mathrm{Cu}$ e $\mathrm{Fe}$, isolada ou conjuntamente, não trouxe benefícios aos parâmetros de produção. Partindo-se da premissa de que estas fontes apresentam maior biodisponibilidade. A suplementação isolada de cada mineral orgânico estudado não mostrou melhor resultado que os tratamentos com os premixes totalmente orgânicos e totalmente inorgânicos. Outros estudos obtiveram resultados semelhantes (FERNANDES et al, 2008; .MACIEL et al, 2010; SALDANHA et al, 2009; MABE et al, 2003; SWIATKIEWICZ E KORELESKI, 2008; PASSOS, 2010; GERALDO et al, 2008)

\subsubsection{IMPORTANCIA DA QUALIDADE DA CASCA DO OVO PARA A INDUSTRIA}

A produção de ovos, como atividade industrial, busca sempre melhorar a eficiência em termos produtivos e econômicos, beneficiando-se do potencial genético apresentado pelas poedeiras. Contudo uma preocupação constante recai sobre a casca dos ovos, motivada pelos prejuízos econômicos associados à redução da qualidade das mesmas além de representar ameaça à saúde dos consumidores, pois a casca também funciona como "embalagem" natural, e, portanto barreira física, que protege seu conteúdo de contaminações externas (HUNTON, 2005).

$\mathrm{Na}$ avicultura de postura, estima-se, que 10 a $15 \%$ dos ovos produzidos por poedeiras comerciais sejam perdidos por apresentarem má qualidade de casca (COUTTS et al., 2007). Esse fato impossibilita sua comercialização para 
consumo e/ou processamento, e os fatores que influenciam na ocorrência dessas cascas consideradas de má qualidade são vários, tais como a genética, idade das poedeiras, práticas de manejo, condições ambientais e principalmente a nutrição (NYS, 2001).

Keshavarz (1994) afirmou que a qualidade da casca decresce expressivamente no final da postura, que pode ser identificada logo após o pico de produção que ocorre ao redor das 35 semanas, com ovos cada vez maiores e cascas finas. Também Roland (1977) relatou perdas maiores em aves com idade avançada, assinalando ser essa variável um problema importante para a avicultura comercial. Além disso, problemas de qualidade interna e de casca do ovo também estão relacionados com a alimentação das aves, portanto, torna-se necessária dieta balanceada de acordo com as exigências da ave durante suas diferentes fases de postura, para que a produção e a qualidade dos ovos sejam otimizadas.

Por exemplo, na fase de pré-postura, rações deficientes em cálcio acabam determinando a diminuição da qualidade da casca dos ovos na fase de produção (MAGALHÃES, 2007). Para se obter boa nutrição é necessário que o animal receba quantidades adequadas de nutrientes, incluindo-se os minerais, que são considerados de grande importância, pois participam de todos os processos bioquímicos corporais (SECHINATO, et al. 2006). Atualmente há interesse crescente em explorar fatores que aumentam a absorção ou utilização de minerais devido a perspectiva de serem mais biodisponíveis (SECHINATO, et al. 2006). Segundo Reddy et al. (1992), às formas orgânicas aumentam a biodisponibilidade dos minerais em relação as formas inorgânicas, o que pode trazer benefícios, tais como: maior taxa de crescimento, maior ganho de peso, maior produção de ovos, melhora na qualidade de carne e ovos, redução da taxa de mortalidade e redução do efeito do estresse.

\subsubsection{MICROMINERAIS E A QUALIDADE OSSEA EM POEDEIRAS EM FASE DE PRODUÇÃO}

Além da má qualidade da casca do ovo, outro problema observado em criações altamente produtivas na indústria avícola moderna é a baixa qualidade 
óssea, relacionada principalmente à osteoporose. A osteoporose pode ser definida como diminuição da mineralização estrutural do osso, levando ao aumento da fragilidade óssea e à susceptibilidade as fraturas (WHITEHEAD \& FLEMING, 2000). A consequência dessa enfermidade pode ser grave, desde fraqueza óssea e deformidades até à quebra, então a osteoporose é um problema importante de bem-estar que causa dor e sofrimento às aves (WEBSTER, 2004).

Baixos valores de massa óssea e aumento no risco a fraturas são característicos em ossos de poedeiras "velhas" (em final do período de postura) e são consequências de mudanças na estrutura do colágeno ósseo e redução na mineralização (SANTOS, 2008). A perda na integridade óssea associada à idade ocorre em parte devido à redução na produção de osteoblastos, as células responsáveis pela deposição da matriz óssea (SANTOS, 2008). Verificou-se que quase $30 \%$ das galinhas que vivem em gaiolas, na fase final da postura tinham um ou mais ossos quebrados durante suas vidas (GREGORY \& WILKINS, 1989).

A densidade mineral óssea pode ser estimada por meio de métodos invasivos e não invasivos, que são divididos em métodos radiológicos e nãoradiológicos (LOUZADA, 1998a). A densitometria óptica radiográfica enquadrase nos métodos não-invasivos radiológicos, e possui custo significativamente inferior aos demais (LOUZADA, 1997; LOUZADA, 1998a), sendo sugerida por Louzada et al. (1998b) como uma boa opção metodológica. Segundo Mazucco (2005), o uso da densitometria para verificar a integridade óssea de poedeiras comerciais durante o segundo ciclo de produção, possibilitou constatar que a perda da massa óssea tem grande contribuição ao problema da fragilidade dos ossos e está associada ao período em que as aves permanecem em postura, quando há grande demanda de cálcio dos ossos para deposição nas cascas dos ovos. Este estudo mostrou que decréscimos na densidade mineral óssea podem ser associados à maior incidência de fraturas em carcaças de poedeiras processadas ao final do segundo ciclo de postura.

A maioria dos estudos sobre os efeitos da nutrição na qualidade da casca e do osso das poedeiras têm se concentrado nos macroelementos cálcio e fósforo $(\mathrm{Ca}, \mathrm{P})$ e na vitamina $\mathrm{D} 3$. Embora seja de conhecimento público que as 
enzimas relacionadas com alguns microelementos são importantes no processo de mineralização, o número de pesquisas sobre a relação entre microelementos e qualidade de casca de ovo e ossos é limitado.

Entre os microelementos importantes de serem suplementados para se obter bom aproveitamento genético em relação a produtividade, qualidade de casca do ovo e prevenção de distúrbios ósseos como a osteoporose, podemos citar o manganês $(\mathrm{Mn})$, o zinco $(\mathrm{Zn})$ e o cobre $(\mathrm{Cu})$, importantes para ampla variedade de processos fisiológicos em todos os animais (MAIORKA \& MACARI, 2002; RICHARDS et al., 2010). Há falta de dados na literatura sobre o efeito do $\mathrm{Zn}$ e do $\mathrm{Mn}$ dietéticos sobre a qualidade óssea em poedeiras. Porém se sabe que a deficiência de $\mathrm{Zn}$ afetou negativamente o metabolismo esquelético em galinhas jovens (WANG et al., 2002) e ratos em crescimento (OVESEN et al., 2001, ROSSI et al., 2001).

\subsubsection{SUPLEMENTAÇÃO DE MANGANÊS ORGÂNICO EM POEDEIRAS}

O manganês atua como ativador de enzimas e constituinte de metaloenzimas, por isso desempenha papel importante na qualidade da casca, também está relacionado com a síntese de mucopolissacarídeos (MABE, 2001). A deficiência deste microelemento compromete a formação da camada mamilar produzindo casca com maior frequência de áreas translúcidas (LEACH e GROSS, 1983). Mabe et al. (2003) sugeriram que a deficiência de minerais como zinco, manganês e cobre, poderia alterar a formação de cristais de calcita e modificar a estrutura cristalográfica da casca do ovo, e consequentemente, afetar suas propriedades mecânicas. A deficiência deste mineral (Mn) determina aumento da produção de ovos sem casca ou de casca mole (SCOTT et al., 1982), forma arredondada com regiões translúcidas próximas ao centro, redução da densidade e resistência da casca, além de queda na produção (LEESON e SUMMERS, 2001).

Variações são verificadas com relação aos teores de suplementação do manganês nas dietas de poedeiras, uma vez que as recomendações são de 33, 30, 20, 70 e 77 ppm, segundo SCOTT et al. (1982), NRC (1994), LEESON e SUMMERS (2005) e ROSTAGNO et al. (2011), respectivamente. NORTH e 
BELL (1993) recomendam de 50 a 70 ppm para aumentar a resistência da casca dos ovos. As cascas de ovos produzidos com deficiência de Mn são mais finas, menos resistentes e contém menor teor de hexosamina e ácido hexurônico do que as produzidas por aves com suprimento normal de Mn (LEACH JR. \& GROSS, 1983). A suplementação com esse microelemento em dietas à base de milho e farelo de soja tem levado a interações com fitatos presentes na dieta, reduzindo sua disponibilidade para a ave. Além desse fato, rações com altos teores de cálcio, frequentemente utilizadas para as poedeiras, podem interferir no aproveitamento desse microelemento (FASSANI et al., 2000).

Segundo Swiatkiewicz \& Koreleski (2008), a substituição de manganês e zinco inorgânicos (em 0, 50 e 100\%) por fontes orgânicas não mostrou influência sobre o desempenho zootécnico, mas o efeito negativo da idade das aves sobre a fragilidade da casca foi atenuado. Holder \& Huntley (1978) não observaram efeito sobre produção e peso dos ovos, conversão alimentar, espessura da casca e gravidade específica com a utilização de $65 \mathrm{ppm}$ de manganês. No entanto, maiores valores para a espessura da casca e gravidade específica foram verificados com teor de $180 \mathrm{ppm}$ de manganês mais 1,0\% de cálcio, via farinha de ostras, em dieta já contendo $3,6 \%$ de cálcio. Whisenhunt \& Maurice (1985) notaram redução no percentual de ovos quebrados de 37 para $27 \%$, quando utilizaram teores de 25 e 200 ppm de manganês, respectivamente, sugerindo que esses resultados foram decorrentes de mudanças na matriz orgânica da casca.

Xiao, et al (2015), ao utilizarem 9 teores de Mn (Mn inorgânico: 0, 25, 50, 100 e 200 mg / kg; Mn orgânico: 25, 50, 100 e 200 mg / kg) para suplementar dieta basal durante 8 semanas em poedeiras de 54 semanas de idade, notaram que não houve diferença na produção de ovos, qualidade de casca e na eficiência alimentar durante 56 e 58 semanas de idade. Porém, ao final de 62 semanas de idade, a suplementação dietética com Mn orgânico ou Mn inorgânico aumentou a espessura, resistência à quebra e módulo de elasticidade da casca do ovo em comparação com o grupo controle, sugerindo que que o $\mathrm{Mn}$ orgânico melhora a qualidade da casca do ovo em poedeiras envelhecidas em comparação com o Mn inorgânico. 


\subsubsection{SUPLEMENTAÇÃO DE ZINCO ORGÂNICO EM POEDEIRAS}

O zinco é um microelemento essencial para aves, pois participa na elaboração do sistema enzimático, envolvendo a síntese de proteína, o metabolismo de carboidratos e outras reações bioquímicas, como fixação do cálcio sob a forma de carbonato de cálcio nos ossos e nos ovos e ativação dos sistemas enzimáticos (BAIAO e CANÇADO, 1997). O excesso de Zn pode diminuir a atividade de outras enzimas como citocromo oxidase, catalase, além de enzimas ferrosas, reduzindo fortemente a ingestão de ração (COTTA, 2002). A deficiência dietética de zinco ocasiona problemas físicos, inclusive lesões de pele, crescimento reduzido, problemas ósseos e articulares, enfraquecimento das penas, redução dos índices de reprodução e na imunidade (SALIM et al., 2008). Também foi observada redução no peso da casca de ovos (NYS et al., 1999) e queda na produção de ovos (LEESON e SUMMERS 2001).

De acordo com Cousins (1985), a absorção de Zn ocorre principalmente no intestino delgado e da mesma forma que ocorre com o Mn, o $\mathrm{Zn}$ tem função de ativador de enzimas e, é constituinte de metaloenzimas, desempenhando importante papel na qualidade da casca, pois está diretamente relacionado com a atividade da anidrase carbônica (MABE, 2001). Segundo o NRC (1994), a recomendação de zinco para poedeiras leves na fase de postura é de $44 \mathrm{mg} / \mathrm{kg}$, enquanto Rostagno et al. (2011) recomendam $72 \mathrm{mg} / \mathrm{kg}$.

Em pesquisa realizada com poedeiras, HUDSON et al. (2004) observaram melhora na qualidade da casca de ovos em aves que tiveram zinco quelatado incluído na dieta em concentração de 160 ppm. Resultado semelhante foi encontrado por XAVIER et al. (2004) que obtiveram melhora na qualidade dos ovos quando incluíram manganês, selênio e zinco orgânico na alimentação das poedeiras, e concluíram que a inclusão desses minerais no segundo ciclo de postura foi benéfica. Moreng (1992) obteve melhora na resistência a quebra e significativa redução dos defeitos de casca quando as aves receberam zinco orgânico $(2 \mathrm{~g} / \mathrm{kg})$, melhora essa que não ocorreu nas aves que receberam a forma inorgânica do produto, este mesmo resultado foi obtido por Balnave \& Zhang (1993) em trabalho semelhante, que concluíram que os resultados foram 
ainda melhores que os obtidos por Moreng (1992) com uma suplementação de $5 \mathrm{~g} / \mathrm{kg}$ de zinco orgânico na dieta. Kienholz (1992) utilizou fontes orgânicas de zinco na concentração de 1 e $2 \mathrm{~g} / \mathrm{kg}$ na alimentação de aves com idade avançada (terceiro ciclo), de 142 até 163 semanas de idade, sob estresse causado por baixo nível de cálcio na dieta, observou melhora na produção e nos parâmetros de qualidade de ovo.

\subsubsection{SUPLEMENTAÇÃO DE COBRE ORGÂNICO EM POEDEIRAS}

O cobre é fundamental para algumas funções metabólicas. Leeson \& Summers (2005), apontam que as principais fontes inorgânicas utilizadas pelas indústrias são o óxido, o sulfato e o carbonato de cobre. Este elemento está também relacionado com o metabolismo do ferro. Dentre suas funções, é considerado essencial na formação óssea (NYS et al, 2003; UAUY et al, 1998) e no desenvolvimento e coloração de penas (SCHEIDELER, 2008).

O cobre faz parte de enzimas envolvidas na fosforilação oxidativa, como por exemplo a citocromo oxidase que é responsável por transportar os elétrons durante a respiração aeróbia e catalisar a redução do oxigênio a água, um passo importante da respiração celular; faz parte da superóxido dismutase, enzima antioxidante que protege as células dos efeitos deletérios originados no metabolismo do oxidativo. O referido elemento atua ainda na manutenção do sistema nervoso; indiretamente está ligado à síntese de hemoglobina por ativar a ferroxidase; contribui na síntese de queratina; além de fazer parte da enzima lisil oxidase, catalisadora na formação do colágeno e da elastina (BERTECHINI, 2006). Apesar de seu papel na formação da casca ainda não estar completamente definido, a deficiência de cobre resulta em alterações no tamanho, forma e textura da casca e está relacionada a alta frequência de ovos de casca fina (GUO et al., 2001 ;BAUMGARTNER, 1978). Dietas com deficiência deste mineral são responsáveis por ossos frágeis e cartilagens espessas, assim como, ovos com cascas frágeis pela má formação da membrana da casca (LEESON \& SUMMERS, 2001). Quando utilizado nas rações em concentração de 169 ppm, o cobre atua como promotor do crescimento em frangos de corte (FISHER, 1973) e quando utilizado a 176 ppm, aumentou a produção de ovos 
(GRIMINGER, 1977). Rostagno et al. (2011) recomendaram $11 \mathrm{mg} / \mathrm{kg}$ de cobre para aves na fase de postura.

Aguiar et al. (2009) avaliaram os parâmetros de desempenho de poedeiras comerciais suplementadas com diferentes microminerais, e concluíram que os elementos zinco, cobre e manganês associados na sua forma orgânica proporcionaram maiores pesos e menores perdas de ovos em aves no final do período de postura e o mineral cobre suplementado isoladamente também diminuiu a perda de ovos por quebra, trincas e ausência de casca. Maciel et al. (2010) avaliaram o desempenho e a qualidade externa dos ovos de poedeiras comerciais suplementadas com $50 \%$ dos minerais zinco, manganês e cobre na forma orgânica, e concluíram que as aves apresentaram melhores resultados entre os tratamentos testados, maior peso do ovo, gravidade específica e menor porcentagem de perda de ovos. Paik (2001) avaliando o uso de zinco metionina, cobre metionina e manganês metionina, isoladamente ou em combinação, observou melhora na produção das aves que receberam o cobre metionina isolado, e a combinação dos três minerais, essa melhora não foi observada para o tratamento com o zinco metionina isolado e para o tratamento onde houve a combinação do cobre com o zinco orgânico.

\subsubsection{USO DE FARINHA DE CARNE E OSSOS NA ALIMENTAÇÃO DE POEDEIRAS}

A farinha de carne e ossos (FCO) é um ingrediente amplamente utilizado nas dietas para frangos de corte e poedeiras comerciais, atuando geralmente como redutor nos custos de formulações, entretanto, sua inclusão depende do conhecimento de sua qualidade, preço e efeito sobre o desempenho animal, incluindo consumo de ração, taxa de conversão alimentar, ganho de peso etc. (FARIA FILHO et al., 2002). Além de reduzir os custos de produção, a inclusão dietética da FCO permite a utilização de produtos processados, que de outra forma precisam ser descartados e podem causar poluição ambiental (NASCIMENTO et al., 2005, NUNES et al., 2005, GENEROSO et al., 2008; ARAÚJO et al., 2011). Para cada tonelada de carne preparada para o consumo humano, cerca de $300 \mathrm{~kg}$ de produtos não consumíveis são descartados, e, 
deste total, $200 \mathrm{~kg}$ são aproveitados para a fabricação de farinha de carne e ossos (LEESON; SUMMERS, 2001). Na maior parte dos países, inclusive no Brasil, devido à Encefalopatia Espongiforme Bovina, não se permite a utilização de farinha de carne e ossos na alimentação de ruminantes, sendo este produto destinado principalmente à alimentação de aves e suínos (GARCIA et al., 2004). Porém, na União Europeia, a farinha de carne e ossos foi totalmente banida da alimentação de animais destinados ao consumo humano (TAYLOR; WOODGATE, 2003), sendo o produto incinerado ou usado na alimentação de cães e gatos.

A farinha de carne e ossos é excelente fonte de proteína, cálcio e fósforo (SHIRLEY; PARSONS, 2001). É um subproduto do processamento de bovinos e suínos que apresenta de 50 a $60 \%$ de proteína em sua composição (RAVINDRAN et al., 2002) podendo variar consideravelmente em função de diversos fatores, como tipo e condições de processamento (LEESON; SUMMERS, 2005) e tipo de material empregado na sua produção (DAWSON; SAVAGE, 1983). A farinha de carne e ossos pode apresentar na faixa de 1700 a $2800 \mathrm{kcal}$ de energia metabolizável para aves (ROSTAGNO et al., 2011) dependendo da quantidade de proteína bruta e do teor de gordura, que geralmente fica ao redor de $12 \%$. Segundo Bellaver (2005) as farinhas de origem animal são alternativas frequentemente usadas, pois asseguram vantagens nutricionais e econômicas na formulação desde que assegurada a sua qualidade. Outras vantagens além do seu conteúdo nutricional, são a melhoria do odor, sabor e textura da ração, aumentando a palatabilidade da ração, bem como sua segurança, por não conter alérgenos ou fatores antinutricionais, permitindo seu uso para ampla gama de dietas para animais (PEREIRA-DASILVA \& PEZZATO, 2000). Também é discutido o efeito benéfico da inclusão de FCO na melhora da qualidade da casca do ovo (WALDROUP \& ADAMS, 1994; SELL \& JEFFREY, 1996). No entanto, sua inclusão é limitada em 10 a $20 \%$, pois pode prejudicar a qualidade sensorial dos ovos, além de trazer problemas nutricionais às aves (BRITO, 2009).

Em estudo conduzido por Çatli et al. (2012) sobre os efeitos do uso de 4\% de FCO na dieta no desempenho produtivo e na qualidade dos ovos de poedeiras no final do ciclo de produção, foi observado que não houve influência 
da FCO no peso corporal das galinhas, no peso dos ovos e na eficiência alimentar, quando comparado ao grupo controle. Porém, observaram que a FCO influenciou negativamente o desempenho produtivo, determinando queda de $1,14 \%$ na produção de ovos quando comparada ao grupo controle; em contraponto, observaram que a FCO influenciou positivamente na altura do albúmen e na espessura e resistência da casca, tornando os ovos produzidos pelas galinhas alimentadas com FCO superiores do ponto de vista de qualidade em relação aos produzidos pelas galinhas do grupo controle.

Resultados diferentes foram encontrados por Bozkurt et al., (2004), que compararam o efeito da FCO em diferentes concentrações na ração $(2 \%, 4 \%$ e $6 \%$ ) no desempenho produtivo e na qualidade dos ovos em poedeiras em fase final de produção. A inclusão de $2 \%$ de FCO aumentou a produção diária de ovos, sem benefício adicional com a adição de mais FCO. Os autores também observaram que a adição de FCO em qualquer concentração diminuiu em $1 \mathrm{~g}$, em média, o peso dos ovos. A gravidade específica dos ovos das galinhas alimentadas com $\mathrm{FCO}$ a $2 \%$ e a $4 \%$ foi maior do que o do grupo controle e a Unidade Haugh dos ovos das galinhas alimentadas com FCO a $6 \%$ foi melhor do que a dos outros tratamentos. Não foram observadas diferenças entre os tratamentos para consumo de ração, conversão alimentar, coloração da gema, espessura e resistência da casca do ovo.

\section{MATERIAL E MÉTODOS}

O experimento foi executado no Centro de Pesquisa em Nutrição e Doenças Nutricionais de Aves nas dependências do Departamento de Clínica Médica, da Faculdade de Medicina Veterinária e Zootecnia da Universidade de São Paulo, no campus da Cidade Universitária (São Paulo - SP). O experimento foi realizado entre os meses de novembro de 2018 a setembro de 2019, totalizando dez meses e obteve aprovação da Comissão de Ética no Uso de Animais (CEUA-FMVZ/USP) sob número 6868180718. 


\subsection{AVES}

Foram utilizadas 480 galinhas poedeiras da linhagem Dekalb White, com idade inicial de 55 semanas (Figura 1) e de 97 semanas ao final do estudo. Antes de integrarem o experimento, as aves foram selecionadas de acordo com o peso (entre $1250 \mathrm{~g} \mathrm{e} 1600 \mathrm{~g}$ ), aparência saudável, desenvolvimento da crista, distância entre esterno e púbis (desejável distância de quatro dedos), abertura do ísquio (desejável dois dedos de abertura) e cloaca rosada e eversível.

Figura 1 - Poedeira Dekalb White com 55 semanas de vida selecionada para o estudo. São Paulo - 2020.

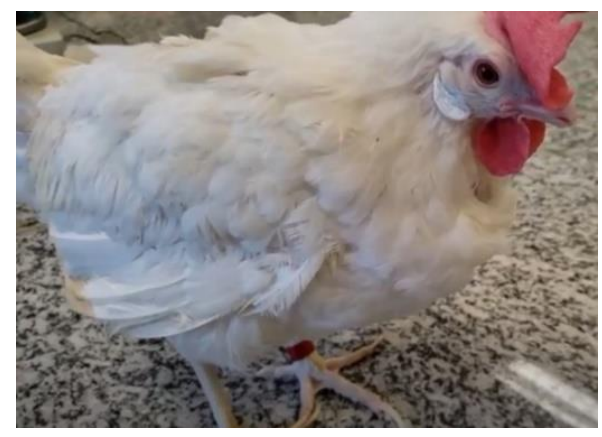

Fonte: Sarah Oliveira (2020).

\subsection{INSTALAÇÕES}

As poedeiras foram distribuídas em blocos, de acordo com os pesos, e alojadas em 240 gaiolas $(0,45 \mathrm{~m} \times 0,25 \mathrm{~m} \times 0,45 \mathrm{~m})$, duas aves por gaiola, com 24 repetições de 2 aves totalizando 48 aves por tratamento (Figura 2). Cada gaiola dispunha de comedouro tipo calha e bebedouro tipo "nipple", sendo que 0 acesso a comida e bebida foram ad libitum. O regime de luz adotado para as aves foi de 16 horas por dia. A temperatura do galpão foi mensurada diariamente com um termômetro Incoterme ${ }^{\circledR}$, os valores foram condensados em máxima e mínima por mês, os quais podem ser observados nos resultados. 
Figura 2 - Aves com 55 dias de idade alojadas nas 240 gaiolas experimentais. São Paulo 2020.

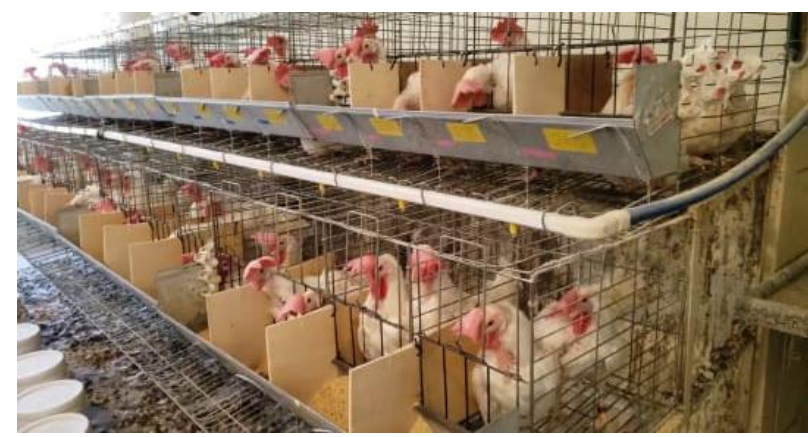

Fonte: Sarah Oliveira (2020).

\subsection{RAÇÕES EXPERIMENTAIS}

As rações foram preparadas no decorrer do experimento, totalizando oito partidas. As concentrações utilizadas dos minerais foram 40 ppm de zinco, 40 ppm de manganês e 7 ppm de cobre, enquanto para os tratamentos com farinha de carne e ossos a inclusão foi de $4 \%$ mediante substituição parcial ao farelo de soja. A mistura dos ingredientes em maior escala utilizados no preparo foi realizada em misturador tipo horizontal helicoidal modelo MIST 200, marca Denan $^{\circledR}$ com capacidade para $200 \mathrm{~kg}$ (Figura 3), enquanto que para a prémistura dos ingredientes de menor inclusão foi utilizado um misturador tipo $\mathrm{Y}$ marca Pilat ${ }^{\circledR}$ com capacidade de 35 kg.(Figura 4).

Figura 3 - Misturador tipo horizontal helicoidal utilizado para ingredientes de maior escala. São Paulo - 2020.

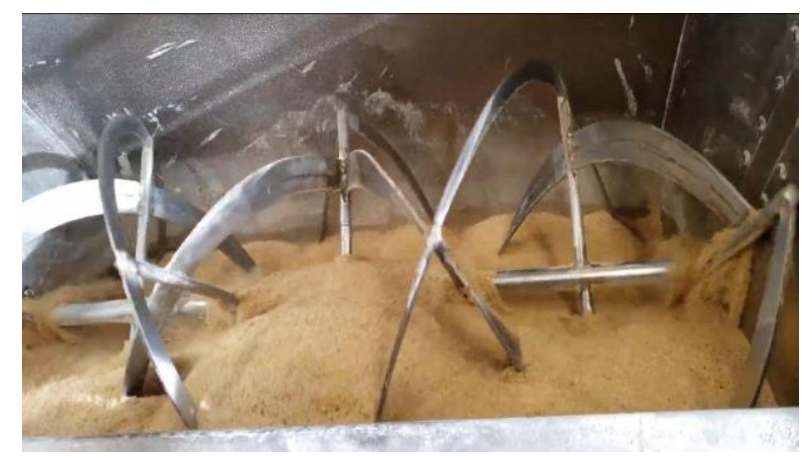

Fonte: Sarah Oliveira (2020). 
Figura 4 - Misturador tipo Y utilizado para inclusão dos premixes nas rações. São Paulo 2020.

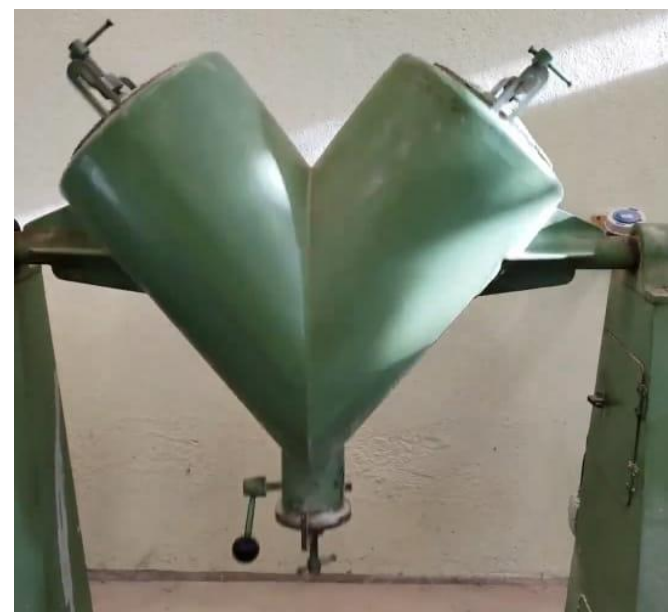

Fonte: Sarah Oliveira (2020).

O delineamento utilizado foi blocos casualizados em esquema fatorial constituído de 10 tratamentos com 24 repetições de 2 aves, totalizando 48 aves por tratamento. O quadro 1 mostra o que diferiu entre os 10 tratamentos.

Quadro 1 - Distribuição dos tratamentos experimentais para avaliar o impacto do uso de fontes de zinco, manganês e cobre isolados ou associados na forma orgânica e a farinha de carne e ossos na dieta de poedeiras Dekalb White com idade inicial de 55 semanas. São Paulo, 2020.

\begin{tabular}{|c|c|c|c|c|c|c|c|}
\hline & \multicolumn{3}{|c|}{ Inorgânico } & \multicolumn{4}{|c|}{ Orgânico (complexado com aminoácidos) } \\
\hline & $\begin{array}{l}\text { Óxido de } \\
\text { Zinco }\end{array}$ & $\begin{array}{l}\text { Óxido de } \\
\text { Manganês }\end{array}$ & $\begin{array}{c}\text { Sulfato } \\
\text { de Cobre }\end{array}$ & Zinco & Manganês & Cobre & $\begin{array}{c}\text { Cobre/Zinco/ } \\
\text { Manganês }\end{array}$ \\
\hline \multicolumn{8}{|c|}{ Com farinha de carne e ossos } \\
\hline Tratamento 1(T1) & $x$ & $\mathrm{X}$ & $\mathrm{X}$ & - & - & - & - \\
\hline Tratamento 2 (T2) & - & $\mathrm{X}$ & $\mathrm{X}$ & $x$ & - & - & - \\
\hline Tratamento 3 (T3) & $x$ & - & $X$ & - & X & - & - \\
\hline Tratamento 4 (T4) & $x$ & $X$ & - & - & - & $\mathrm{X}$ & - \\
\hline Tratamento 5 (T5) & - & - & - & - & - & - & $x$ \\
\hline \multicolumn{8}{|c|}{ Sem farinha de carne e ossos } \\
\hline Tratamento 6 (T6) & $x$ & $\mathrm{X}$ & $\mathrm{X}$ & - & - & - & - \\
\hline Tratamento 7 (T7) & - & $X$ & $x$ & $x$ & - & - & - \\
\hline Tratamento 8 (T8) & $x$ & - & $\mathrm{x}$ & - & $x$ & - & - \\
\hline Tratamento 9 (T9) & $x$ & $\mathrm{X}$ & - & - & - & $x$ & - \\
\hline Tratamento $10(\mathrm{~T} 10)$ & - & - & - & - & - & - & $\mathrm{X}$ \\
\hline
\end{tabular}

Fonte: Sarah Oliveira (2020). 
As rações foram formuladas de acordo com os padrões utilizados na produção de ovos no Brasil, baseadas em milho e soja, e com a presença de $4 \%$ de farinha de carne e ossos em substituição ao farelo de soja em metade dos tratamentos (T1 a T5). A Tabela 1 mostra a composição das dietas formuladas. A composição bromatológica (matéria seca, matéria mineral, proteína bruta e fósforo) das oito batidas feitas durante o experimento será apresentada nos resultados. Para cálculo da matéria seca da ração oferecida para as poedeiras foram coletadas amostras de cada tratamento, as quais foram secas a $105^{\circ} \mathrm{C}$ em estufa de circulação forçada de ar durante 12 horas. Para o cálculo da matéria mineral essas mesmas amostras foram posteriormente queimadas em mufla a $600^{\circ} \mathrm{C}$ por pelo menos 3 horas. A determinação da proteína bruta foi feita por meio da determinação do nitrogênio total (micro-Kjeldahl) segundo a AOAC (2000). O teor de fósforo foi determinado pelo método de Fiske-Subbarow (1925).

Tabela 1 - Composição das dietas experimentais. São Paulo, 2020.

\begin{tabular}{|l|l|l|}
\hline Ingrediente & T1 a T5 & T6 a T10 \\
\hline Milho moído & $130,4 \mathrm{~kg}$ & $125,2 \mathrm{~kg}$ \\
\hline Farelo de soja 46 & $40,31 \mathrm{~kg}$ & $48,76 \mathrm{~kg}$ \\
\hline $\begin{array}{l}\text { Farinha de carne e osso } \\
\text { 45\%PB }\end{array}$ & $7,73 \mathrm{~kg}$ & - \\
\hline Calcário calcítico 36\% & $19,74 \mathrm{~kg}$ & $20,57 \mathrm{~kg}$ \\
\hline Fosfato bicálcico & - & $2,20 \mathrm{~kg}$ \\
\hline Óleo degomado de soja & - & $1,52 \mathrm{~kg}$ \\
\hline Sal comum & $413 \mathrm{~g}$ & $652,4 \mathrm{~g}$ \\
\hline DL metionina 98\% & $333 \mathrm{~g}$ & $309,2 \mathrm{~g}$ \\
\hline Bicarbonato de sódio & $374 \mathrm{~g}$ & $134 \mathrm{~g}$ \\
\hline Cloreto de colina 60\% & $108 \mathrm{~g}$ & $93 \mathrm{~g}$ \\
\hline Enradin 8\% & $25 \mathrm{~g}$ & $25 \mathrm{~g}$ \\
\hline Ronozyme Hiphos M & $12 \mathrm{~g}$ & $12 \mathrm{~g}$ \\
\hline Premix vitamínico & $200 \mathrm{~g}$ & $200 \mathrm{~g}$ \\
\hline Premix mineral & $300 \mathrm{~g}$ & $300 \mathrm{~g}$ \\
\hline
\end{tabular}

Fonte: Sarah Oliveira (2020).

\subsection{MÉTODOS}

A fase experimental teve duração de 10 meses, nas quais foram mensurados os seguintes parâmetros: 


\subsubsection{Desempenho produtivo}

Foram avaliados o consumo de ração ( $\mathrm{g}$ ) semanal; produção diária de ovos por ave; conversão alimentar por dúzia ( $\mathrm{kg} /$ dúzia de ovos) e peso médio dos ovos (g). Os dados de peso dos ovos foram transformados em média bimestral do peso médio semanal dos ovos.

\subsubsection{Consumo de ração}

Cada gaiola possuía um balde para colocar a ração experimental (Figura 5). Todos os baldes utilizados no experimento foram identificados e pesados vazios para ter seu peso descontado posteriormente. O controle do consumo de ração foi realizado uma vez por semana, quando as sobras do comedouro eram coletadas e pesadas, somando-as às sobras dos baldes. O consumo foi calculado pela diferença de pesos entre a quantidade de ração fornecida e sobras no final do período. A balança utilizada para estas pesagens foi a Toledo do Brasil $\circledast$, digital modelo exata II, com capacidade de $5 \mathrm{~kg}$ e sensibilidade de 1 g.

Figura 5 - Galpão organizado com o auxílio de baldes identificados por gaiola. São Paulo 2020.

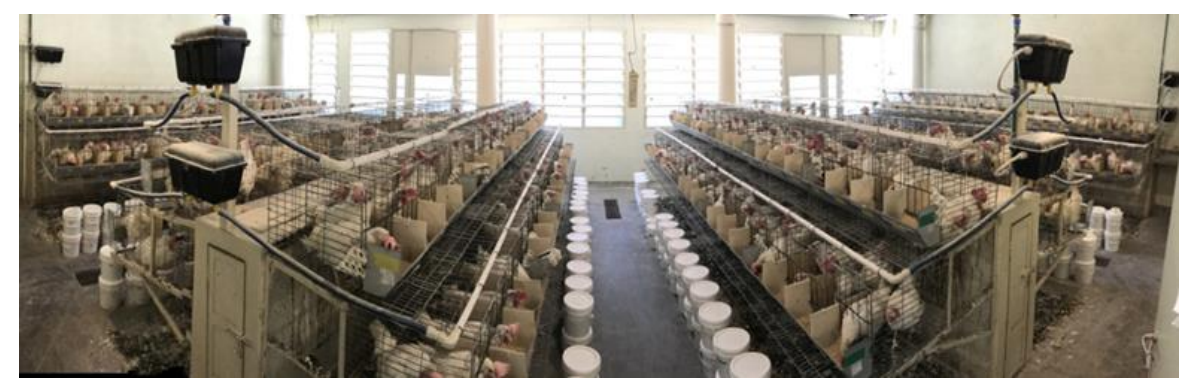

Fonte: Sarah Oliveira (2020).

\subsubsection{Produção de ovos por ave por semana}

Os ovos foram coletados diariamente às 13:00 horas. A produção média de ovos por período foi calculada pelo número total de ovos produzidos na gaiola, divididos pelo número de aves por gaiola por semana. 


\subsubsection{Conversão alimentar por dúzia}

A conversão alimentar por dúzia foi calculada semanalmente dividindo o peso total da ração consumida pela sua respectiva produção de ovos semanal expressa em dúzias. O resultado final foi dado em quilograma por dúzia de ovos.

\subsubsection{Peso dos ovos}

Semanalmente todos os ovos de uma produção diária eram coletados e pesados individualmente em uma balança digital Ohaus® modelo adventurer com capacidade de $1,5 \mathrm{~kg}$ e sensibilidade de 0,01 g (Figura 6).

Figura 6 - Pesagem do ovo. São Paulo- 2020.

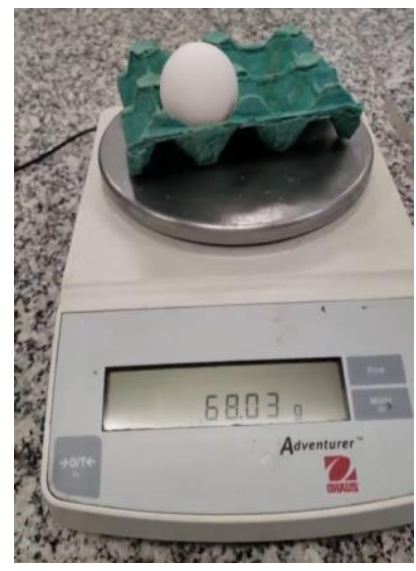

Fonte: Sarah Oliveira (2020).

\subsubsection{Qualidade interna e externa do ovo}

Foram mensuradas: a gravidade específica $\left(\mathrm{g} / \mathrm{cm}^{3}\right)$; unidade Haugh (UH); altura do albúmen; cor da gema do ovo; espessura da casca (mm); peso da casca (g); porcentagem de casca (\%); resistência da casca; e classificação do ovo. Essas análises foram realizadas a cada oito semanas, em seis momentos, durante os dez meses do período experimental. Nesses momentos também foi coletado um ovo por gaiola para tais aferições, sendo as análises feitas por meio do equipamento EggTester ${ }^{\circledR}$ DET6000, toda a produção do dia foi disponibilizada. 


\subsubsection{Gravidade específica}

O primeiro parâmetro a ser analisado foi a gravidade específica (GE). Os ovos foram mergulhados em soluções salinas com diferentes densidades que variavam de $1,050 \mathrm{~g} / \mathrm{cm}^{3}$ até $1,110 \mathrm{~g} / \mathrm{cm}^{3}$ com intervalo de $0,005 \mathrm{~g} / \mathrm{cm}^{3}$. Estas soluções foram preparadas conforme recomendação de Castelló et al., (1989). A técnica é baseada no princípio da flutuação, onde os ovos são imersos em recipiente contendo soluções salinas em ordem crescente de densidade. Foi considerada a densidade do ovo aquela em que o mesmo flutuou (Figura 7).

Figura 7 - Determinação da gravidade específica do ovo. São Paulo - 2020.

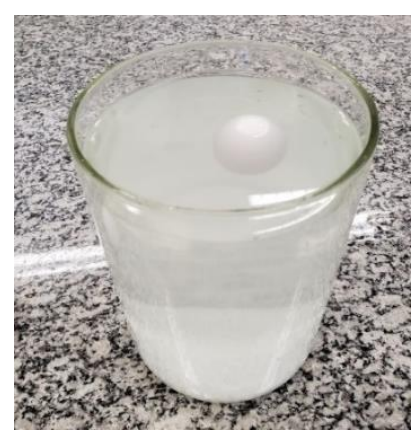

Fonte: Sarah Oliveira (2020).

\subsubsection{Unidade Haugh}

A unidade Haugh foi mensurada utilizando o EggTester ${ }^{\circledR}$ DET6000, que calculou instantaneamente com base no peso do ovo e altura do albúmen seu valor (Figura 8).

Figura 8 - Determinação eletrônica da unidade Haugh por meio do aparelho EggTester ${ }^{\circledR}$ DET6000. São Paulo - 2020.

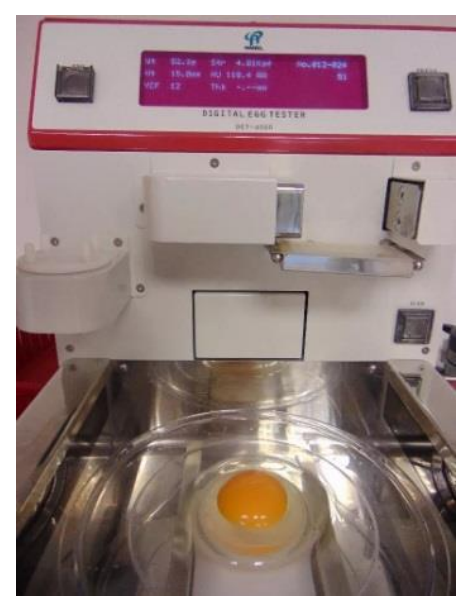


Fonte: Sarah Oliveira (2020).

\subsubsection{Altura do albúmen}

A altura do albúmen foi mensurada por meio do EggTester ${ }^{\circledR}$ DET6000, que com a ajuda de raios lasers paralelos determinou a altura do albúmen em milímetros.

\subsubsection{Cor da gema}

A análise da cor das gemas dos ovos foi feita por colorimetria por meio de duas metodologias, utilizando o Yolk Colour Fan, com 16 escalas de cor de gema que variam de amarelo claríssimo à laranja escuro (Figura 9), e por meio do equipamento EggTester ${ }^{\circledR}$ DET6000.

Figura 9 - Determinação da cor da gema com Yolk Colour Fan. São Paulo - 2020.

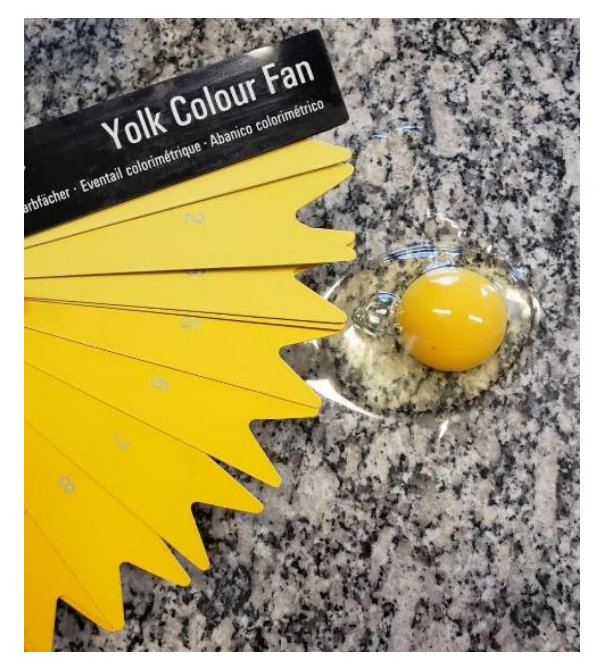

Fonte: Sarah Oliveira (2020).

\subsubsection{Espessura de casca}

A espessura de casca foi aferida após lavagem das cascas em água corrente e secagem em estufa, com circulação forçada de ar a $60^{\circ} \mathrm{C}$ por $12 \mathrm{~h}$. As espessuras foram determinadas em três regiões, por meio de micrômetro digital Ames $^{\circledR} 25 \mathrm{M}-5$, que possui alta precisão e repetibilidade (Figura 10). Estas determinações seguiram o descrito por Souza et al. (1984). 
Figura 10 - Espessura de casca com micrômetro digital Ames® 25M-5. São Paulo - 2020.

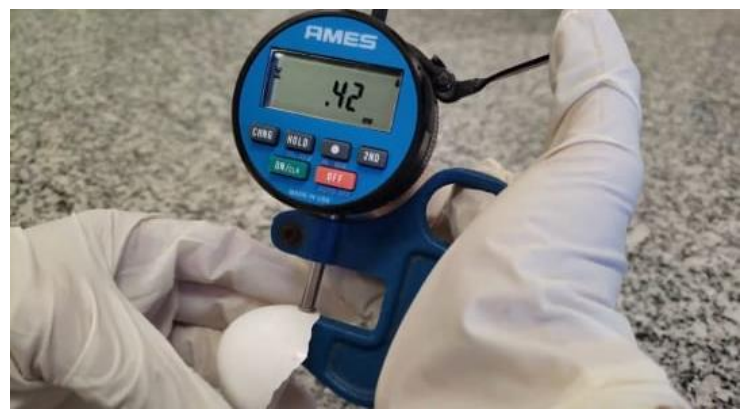

Fonte: Sarah Oliveira (2020).

\subsubsection{Porcentagem de casca}

A análise de peso de casca foi feita após lavagem com água corrente e secagem em estufa com circulação forçada de ar a $60^{\circ} \mathrm{C}$ durante 24 horas. Todas as cascas foram pesadas individualmente em balança digital de $1,5 \mathrm{~kg} \mathrm{e}$ sensibilidade de 0,001g. A porcentagem da casca foi determinada por meio da razão entre o peso da casca e o peso total do ovo.

\subsubsection{Resistência da casca}

A resistência da casca foi mensurada utilizando o equipamento EggTester $^{\circledR}$ DET6000 (Figura 11), o qual aplicava pressão a baixa velocidade na casca até que esta cedesse, medindo assim a força de quebra da casca do ovo. Unidade expressa em quilograma-força.

Figura 11 - Determinação eletrônica da resistência da casca com o aparelho EggTester ${ }^{\circledR}$ DET6000. São Paulo - 2020.

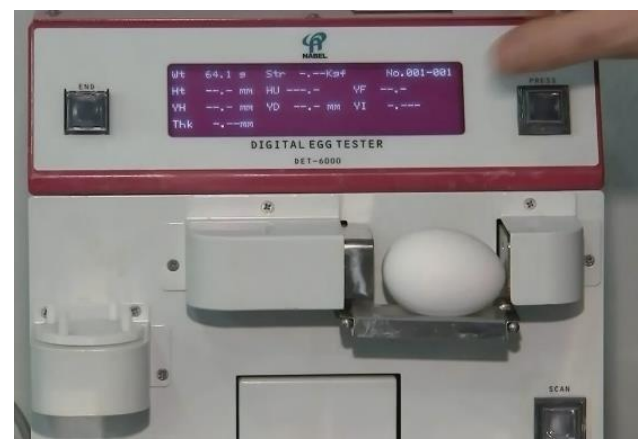

Fonte: Sarah Oliveira (2020). 


\subsubsection{Classificação dos ovos}

A classificação dos ovos em AA, A ou B foi realizada pelo equipamento EggTester ${ }^{\circledR}$ DET6000, por meio do índice de gema, que é calculado dividindo a altura da gema pelo diâmetro da gema do ovo quebrado em uma superfície plana. À medida que a deterioração do ovo progride, a pontuação no índice de gema torna-se mais baixa, porque a estrutura da fibra da membrana vitelina diminui e a força da membrana diminui com o tempo. A pontuação do índice de gema é calculada pela seguinte fórmula: $\mathrm{YI}=\mathrm{YH} / \mathrm{YD}$, onde: $\mathrm{YI}$ : Índice de gema YH: Altura da gema de ovo YD: Diâmetro da gema de ovo. Para análise estatística esses valores foram convertidos em números: $A A=1, A=2$ e $B=3$, sendo que quanto menor o número, maior a qualidade do ovo.

\subsubsection{Ovoscopia}

A ovoscopia foi realizada semanalmente em 15 ovos por tratamento (Figura 12), da $26^{\circ}$ até a $42^{\circ}$ semana do estudo, sendo que a análise dos ovos só foi feita após três dias de sua coleta, para que assim a avaliação de transluscência fosse possível. A ovoscopia foi feita em câmara escura com 15 feixes de luz, um por ovo, e leitura foi realizada através de metodologia de categorização dos ovos em 3 escores de severidade:

- Escore 1: poucos pontos ou ausência de pontos de translucência;

- Escore 2: alguns pontos de translucência distribuídos ao longo da superfície da casca;

- Escore 3: muitos pontos ao longo de toda a superfície da casca ou presença de "janelas".

Os escores de um total de 16 semanas foram condensados em 8 momentos para análise estatística, mostrando o escore médio dos dados. 
Figura 12 - Ovoscopia em câmara escura. São Paulo - 2020.

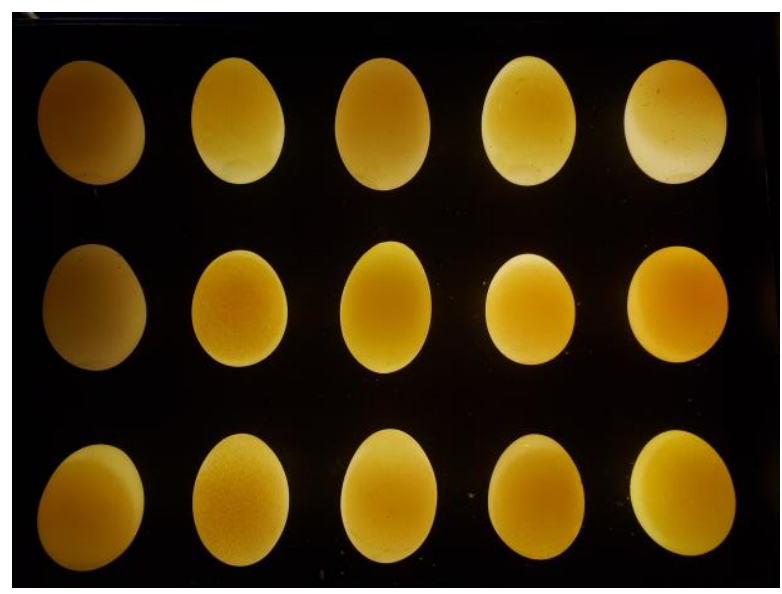

Fonte: Sarah Oliveira (2020).

\subsubsection{Saúde das aves}

Para acompanhar a saúde das poedeiras que participaram do estudo, todas as aves foram pesadas bimestralmente, momento em que foram realizados exames físicos gerais e coleta de sangue de 70 aves por período, sete por tratamento, para análise da atividade da enzima superóxido dismutase. Ao final do estudo, foi realizado teste de densitometria óssea em uma amostra de 10 aves por tratamento, totalizando cem aves para possível inferência da qualidade óssea.

\subsubsection{Peso das aves}

Todas as aves foram pesadas individualmente a cada 8 semanas em uma balança suspensa digital Quantum Sports ${ }^{\circledR}$ com capacidade de $40 \mathrm{~kg}$ e sensibilidade de $20 \mathrm{~g}$.

\subsubsection{Superóxido dismutase}

A cada oito semanas, foram sorteadas sete aves por tratamento, totalizando 70 poedeiras, para a coleta de sangue para a mensuração da atividade da enzima superóxido dismutase (SOD). Logo após a coleta, o sangue 
foi centrifugado e o plasma foi separado. A atividade da SOD foi feita a partir do plasma, mediante uso do kit comercial SD 125 da marca Randox ${ }^{\circledR}$, em analisador bioquímico automatizado da marca Labtest ${ }^{\circledR}$ modelo Labmax $^{\circledR} 240$.

\subsubsection{Densitometria óssea}

No final do período experimental, 10 aves por tratamento foram abatidas por injeção de tiopental intracardíaca para análise da qualidade dos ossos. A análise densitométrica foi realizada por meio de imagens radiográficas das tíbias direitas. Como referencial densitométrico nas tomadas radiográficas foi utilizado penetrômetro (Figura 13), escada de alumínio (liga 6063, ABNT) com 20 degraus (5x25 $\mathrm{mm}^{2}$ de área), radiografado concomitantemente às peças ósseas (ARAÚJO et al., 2003). No momento da aquisição de imagens, foi fixado o penetrômetro ao chassi para a padronização do sistema de tonalidades e posteriormente mensurado da densidade óssea. Após a captura das imagens, estas foram salvas em formato JPEG e analisadas com auxílio do software (Image J 146 \& National Insitute of Health,USA), a partir do qual foi determinada a densidade óptica óssea em milímetros de alumínio (mmAl).

Figura 13 - Radiografia das tíbias de ave com penetrômetro. São Paulo - 2020.

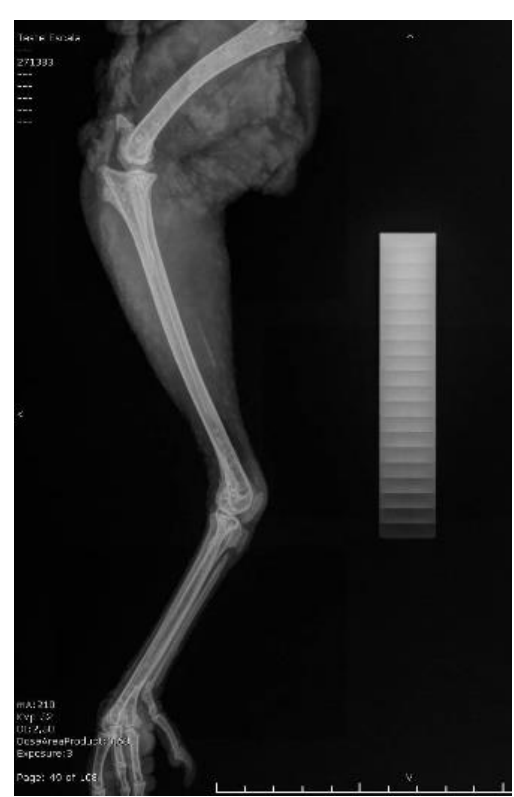

Fonte: Sarah Oliveira (2020). 


\subsection{ANÁLISE ESTATÍSTICA}

Os dados foram analisados pelo programa Statistical Analysis System (SAS Institute Inc., 2010), sendo anteriormente verificada a normalidade dos resíduos pelo teste de Shapiro-Wilk. Todos os dados foram submetidos à análise de variância, que separou como causas de variação o efeito de fatores (tipo de minerais e fontes de proteína) e suas interações, efeito de bloco e o fator medidas repetidas no tempo referentes aos diferentes momentos de coleta, utilizando o procedimento MIXED. O modelo incluiu o efeito de fatores e suas interações como fatores fixos e o efeito de bloco como fator aleatório. Para as análises, foram testadas 15 diferentes estruturas de covariância, sendo que a que melhor se ajustou ao modelo estatístico foi escolhida baseando-se no menor valor do critério de informação Akaike corrigido (AICC) (WANG e GOONEWARDENE, 2004). Os efeitos de fatores e suas interações foram decompostos, utilizando 0,05 como nível de significância através do teste LSD. Para análise da densitometria óssea foi feito o teste de Tukey para comparação entre as médias.

\section{RESULTADOS}

Os resultados obtidos no presente estudo foram descritos e serão apresentados por meio de tabelas e/ou gráficos.

\subsection{Análise bromatológica e temperatura do galpão}

$\mathrm{Na}$ sequência serão apresentados os resultados obtidos das análises bromatológicas e monitoria da temperatura no interior do galpão.

\subsubsection{Bromatologia}

A análise bromatológica das 8 batidas de ração oferecidas para as aves está apresentada na Tabela 2. A proteína bruta na batida 2 do tratamento 7 se destaca de todos os outros tratamentos, com $34,7 \%$. 
Tabela 2 - Composição das rações oferecidas para as poedeiras durante o período experimental, considerando matéria seca (MS), matéria mineral $(\mathrm{MM})$, proteína bruta $(\mathrm{PB})$ e fósforo $(\mathrm{P})$. São Paulo, 2020.

\begin{tabular}{|c|c|c|c|c|c|c|c|c|c|c|}
\hline & $\mathrm{T} 1$ & $\mathrm{~T} 2$ & T3 & $\mathrm{T} 4$ & T5 & T6 & $\mathrm{T} 7$ & $\mathrm{~T} 8$ & T9 & T10 \\
\hline & \multicolumn{10}{|c|}{ BATIDA 1} \\
\hline$\% \mathrm{MS}$ & 86,61 & 86,91 & 87,52 & 87,54 & 86,93 & 87,61 & 88,42 & 87,19 & 86,06 & 87,72 \\
\hline$\% \mathrm{MM}$ & 20,03 & 15,29 & 17,88 & 18,62 & 18,45 & 20,40 & 17,52 & 17,85 & 16,20 & 18,53 \\
\hline \%РB & 17,84 & 19,58 & 16,36 & 17,29 & 12,45 & 17,87 & 15,68 & 19,15 & 15,03 & 18,18 \\
\hline \multirow[t]{2}{*}{$\% \mathrm{P}$} & 0,57 & 0,56 & 0,59 & 0,54 & 0,48 & 0,67 & 0,66 & 0,59 & 0,81 & 0,66 \\
\hline & \multicolumn{10}{|c|}{ BATIDA 2} \\
\hline$\% \mathrm{MS}$ & 85,24 & 87,16 & 87,53 & 87,53 & 87,77 & 86,93 & 86,90 & 88,38 & 86,67 & 85,72 \\
\hline$\% \mathrm{MM}$ & 16,22 & 18,39 & 19,60 & 17,98 & 20,07 & 16,84 & 15,23 & 21,30 & 16,38 & 14,38 \\
\hline$\% \mathrm{~PB}$ & 19,21 & 16,63 & 16,66 & 16,58 & 18,07 & 19,52 & 34,70 & 19,30 & 23,54 & 16,51 \\
\hline \multirow[t]{2}{*}{$\% \mathrm{P}$} & 0,81 & 0,89 & 0,85 & 0,83 & 0,99 & 0,81 & 0,75 & 0,83 & 0,88 & 0,84 \\
\hline & \multicolumn{10}{|c|}{ BATIDA 3} \\
\hline$\% \mathrm{MS}$ & 85,79 & 86,64 & 88,38 & 88,31 & 84,22 & 88,87 & 89,36 & 86,43 & 89,12 & 89,00 \\
\hline$\% \mathrm{MM}$ & 23,55 & 18,68 & 16,61 & 17,23 & 20,93 & 16,30 & 20,24 & 17,15 & 15,88 & 17,19 \\
\hline$\% \mathrm{~PB}$ & 16,11 & 16,39 & 17,04 & 15,82 & 15,85 & 17,63 & 16,50 & 16,39 & 16,27 & 16,37 \\
\hline \multirow[t]{2}{*}{$\% \mathrm{P}$} & 0,70 & 0,78 & 0,76 & 0,77 & 0,87 & 0,82 & 0,78 & 0,72 & 0,77 & 0,85 \\
\hline & \multicolumn{10}{|c|}{ BATIDA 4} \\
\hline$\% \mathrm{MS}$ & 88,05 & 87,25 & 87,99 & 88,42 & 87,63 & 88,05 & 88,98 & 88,74 & 88,02 & 88,29 \\
\hline$\% \mathrm{MM}$ & 19,10 & 16,14 & 18,51 & 20,87 & 16,57 & 16,45 & 21,71 & 16,70 & 17,61 & 15,19 \\
\hline$\% \mathrm{~PB}$ & 15,28 & 15,87 & 15,61 & 15,90 & 15,95 & 14,25 & 14,29 & 15,76 & 14,78 & 14,95 \\
\hline \multirow[t]{2}{*}{$\% \mathrm{P}$} & 0,53 & 0,52 & 0,65 & 0,63 & 0,56 & 0,64 & 0,57 & 0,63 & 0,66 & 0,74 \\
\hline & \multicolumn{10}{|c|}{ BATIDA 5} \\
\hline$\% \mathrm{MS}$ & 88,25 & 88,81 & 87,97 & 88,11 & 88,03 & 88,47 & 88,02 & 88,68 & 88,68 & 88,16 \\
\hline$\% \mathrm{MM}$ & 13,81 & 19,23 & 16,09 & 16,17 & 17,80 & 18,66 & 17,89 & 19,93 & 18,86 & 18,51 \\
\hline$\% \mathrm{~PB}$ & 17,20 & 16,97 & 14,94 & 16,55 & 16,96 & 16,35 & 15,75 & 11,51 & 16,12 & 12,09 \\
\hline \multirow[t]{2}{*}{$\% \mathrm{P}$} & 0,58 & 0,42 & 0,54 & 0,51 & 0,52 & 0,56 & 0,49 & 0,48 & 0,53 & 0,52 \\
\hline & \multicolumn{10}{|c|}{ BATIDA 6} \\
\hline$\% \mathrm{MS}$ & 87,61 & 88,20 & 87,59 & 88,50 & 88,26 & 88,58 & 88,25 & 88,73 & 87,15 & 88,23 \\
\hline$\% \mathrm{MM}$ & 20,05 & 19,26 & 17,08 & 19,69 & 21,93 & 20,08 & 16,79 & 16,92 & 13,96 & 19,65 \\
\hline$\% \mathrm{~PB}$ & 15,76 & 16,74 & 16,36 & 15,70 & 16,42 & 15,81 & 16,65 & 16,46 & 16,09 & 17,38 \\
\hline \multirow[t]{2}{*}{$\% \mathrm{P}$} & 0,51 & 0,55 & 0,52 & 0,50 & 0,50 & 0,50 & 0,52 & 0,49 & 0,51 & 0,48 \\
\hline & \multicolumn{10}{|c|}{ BATIDA 7} \\
\hline$\% \mathrm{MS}$ & 88,24 & 88,55 & 88,35 & 88,65 & 88,75 & 88,89 & 89,00 & 88,27 & 88,59 & 88,47 \\
\hline$\% \mathrm{MM}$ & 16,45 & 17,49 & 15,86 & 15,25 & 19,85 & 16,93 & 16,91 & 15,26 & 14,05 & 20,23 \\
\hline$\% \mathrm{~PB}$ & 18,86 & 15,42 & 17,26 & 15,53 & 16,64 & 15,59 & 15,03 & 17,06 & 16,25 & 16,33 \\
\hline \multirow[t]{2}{*}{$\% \mathrm{P}$} & 0,50 & 0,54 & 0,59 & 0,42 & 0,43 & 0,45 & 0,66 & 0,47 & 0,50 & 0,45 \\
\hline & \multicolumn{10}{|c|}{ BATIDA 8} \\
\hline$\% \mathrm{MS}$ & 88,57 & 88,32 & 87,80 & 85,93 & 88,49 & 87,99 & 88,30 & 88,81 & 88,49 & 88,49 \\
\hline$\% \mathrm{MM}$ & 19,58 & 21,46 & 14,69 & 14,03 & 16,65 & 14,31 & 17,24 & 17,26 & 17,34 & 18,28 \\
\hline$\% \mathrm{~PB}$ & 15,87 & 16,10 & 17,12 & 15,47 & 16,27 & 18,17 & 16,49 & 16,88 & 19,45 & 17,39 \\
\hline$\% \mathrm{P}$ & 0,44 & 0,48 & 0,55 & $\begin{array}{l}0,48 \\
\text { Font }\end{array}$ & $\begin{array}{l}0,78 \\
\text { : Sarah }\end{array}$ & $\begin{array}{l}0,56 \\
\text { Oliveir }\end{array}$ & $\begin{array}{c}0,55 \\
(2020)\end{array}$ & 0,56 & 0,43 & 0,43 \\
\hline
\end{tabular}




\subsubsection{Temperatura}

A temperatura no interior do galpão pode ser observada na Tabela 3, onde notamos que as maiores temperaturas foram atingidas nos meses de dezembro (2018), janeiro (2019) e fevereiro (2019) que correspondem ao verão no Brasil.

Tabela 3 - Média da temperatura no interior do galpão experimental. São Paulo, 2020.

\begin{tabular}{lcc} 
& \multicolumn{2}{c}{ Temperatura ( $\left.{ }^{\circ} \mathrm{C}\right)$} \\
\cline { 2 - 3 } Meses & Máxima & Mínima \\
\hline Nov/18 & 26,5 & 22,5 \\
Dez/18 & 30,2 & 26,4 \\
Jan/19 & 31,4 & 24,5 \\
Fev/19 & 30,5 & 20,7 \\
Mar/19 & 29,0 & 21,4 \\
Abr/19 & 28,3 & 22,1 \\
Mai/19 & 27,2 & 20,0 \\
Jun/19 & 24,9 & 19,1 \\
Jul/19 & 22,7 & 16,7 \\
Ago/19 & 23,1 & 16,4 \\
Set/19 & 25,9 & 19,9 \\
& Fonte: Sarah Oliveira $(2020)$.
\end{tabular}

4.2 Resultados do desempenho produtivo

Na sequência serão apresentados os resultados obtidos, durante as 42 semanas do período experimental, em relação ao desempenho produtivo.

\subsubsection{Consumo de ração}

A Tabela 4 mostra o consumo médio de ração das poedeiras durante o período experimental. Houve interação entre tempo, fonte de mineral e fonte proteica $(P<0,001)$. Os dias influenciaram o consumo de forma que ao final do estudo as aves estavam comendo mais. Na coleta 1 ( 0 dias, $P=0,0425)$ e 2 (60 dias, $P<0,001$ ), houve interação entre a fonte de proteína e mineral fornecido, podendo ser observados nos Gráficos 1 e 2 respectivamente, que ilustram menor consumo para as poedeiras que receberam o tratamento 7 , com zinco orgânico e farelo de soja como fonte exclusiva de proteína. No gráfico 3 nota-se a média geral da interação proteína e mineral $(P=0,0336)$, também pode-se identificar menor consumo médio para as aves do tratamento 7 , contrastando com 0 
tratamento 6 , com os três minerais na forma inorgânica e farelo de soja como fonte exclusiva de proteína, que foi o tratamento que proporcionou o maior consumo de ração durante o experimento.

Tabela 4 - Consumo médio de ração por ave por semana (g/ave/semana) em poedeiras Dekalb White, com idade inicial de 55 semanas que receberam $4 \%$ de farelo de carne e ossos (FCO) em substituição parcial ao farelo de soja e os elementos zinco, manganês e cobre isoladamente e associados na forma orgânica durante 42 semanas. São Paulo, 2020.

\begin{tabular}{|c|c|c|c|c|c|c|c|c|c|c|c|c|}
\hline \multirow{2}{*}{ Tempo } & \multicolumn{2}{|c|}{ Fonte de proteína } & \multicolumn{5}{|c|}{ Fonte de Mineral } & \multirow{2}{*}{ Média } & \multirow{2}{*}{ EPM } & \multicolumn{3}{|c|}{ Pvalor } \\
\hline & $\mathrm{FCO}^{*}$ & $\mathrm{FS}^{* *}$ & $\operatorname{lnorg}^{1}$ & Zn org ${ }^{2}$ & Mn org ${ }^{3}$ & Cu org ${ }^{4}$ & Org $^{5}$ & & & Proteína & Mineral & Proteína*mineral \\
\hline 0 dias & 730,50 & 699,56 & 722,38 & 697,07 & 717,75 & 715,16 & 722,81 & 715,03 & 4,49 & 0,0007 & 0,3537 & 0,0425 \\
\hline 60 dias & 705,60 & 697,11 & 710,49 & 669,54 & 716,22 & 704,72 & 705,80 & 701,36 & 2,47 & 0,0871 & $<0,0001$ & $<0,0001$ \\
\hline 120 dias & 704,08 & 706,93 & 713,53 & 700,19 & 710,40 & 701,01 & 702,40 & 705,51 & 2,33 & 0,5400 & 0,2502 & 0,7389 \\
\hline 180 dias & 724,65 & 723,75 & 728,33 & 720,25 & 731,38 & 717,40 & 723,64 & 724,21 & 2,79 & 0,8721 & 0,4978 & 0,5375 \\
\hline 240 dias & 763,44 & 760,99 & 768,39 & 756,12 & 767,08 & 756,62 & 762,89 & 762,22 & 3,29 & 0,7089 & 0,6608 & 0,1336 \\
\hline 300 dias & 760,88 & 770,11 & 771,08 & 756,10 & 784,64 & 752,99 & 762,68 & 765,50 & 4,32 & 0,2872 & 0,1387 & 0,1650 \\
\hline Média & 731,52 & 726,41 & 735,70 & 716,53 & 737,91 & 724,65 & 730,04 & 728,47 & 1,58 & 0,2950 & 0,0423 & 0,0336 \\
\hline \multicolumn{3}{|c|}{ P valor } & & & & & & & & & & \\
\hline Dias & & $<0,0001$ & & & & & & & & & & \\
\hline Proteína* & & 0,0043 & & & & & & & & & & \\
\hline Mineral* & & 0,0004 & & & & & & & & & & \\
\hline Proteína* & eral*dias & $<0,0001$ & & & & & & & & & & \\
\hline
\end{tabular}

Fonte: Sarah Oliveira (2020).

*FCO: farinha de carne e ossos; **FS: farelo de soja;

1'Inorg: tratamento controle com as fontes de zinco, manganês e cobre apenas sob a forma inorgânica; ${ }^{2} \mathrm{Zn}$ org: zinco complexado com aminioácidos; ${ }^{3} \mathrm{Mn}$ org: manganês complexado com aminoácidos; ${ }^{4} \mathrm{Cu}$ org: cobre complexado com aminoácidos; ${ }^{5} \mathrm{Org}$ : fontes de zinco, manganês e cobre complexados com aminoácidos. 
Gráfico 1 - Interação do consumo de ração (g/ave) entre proteína e mineral na coleta 1 (0 dias) em poedeiras Dekalb White. São Paulo, 2020.

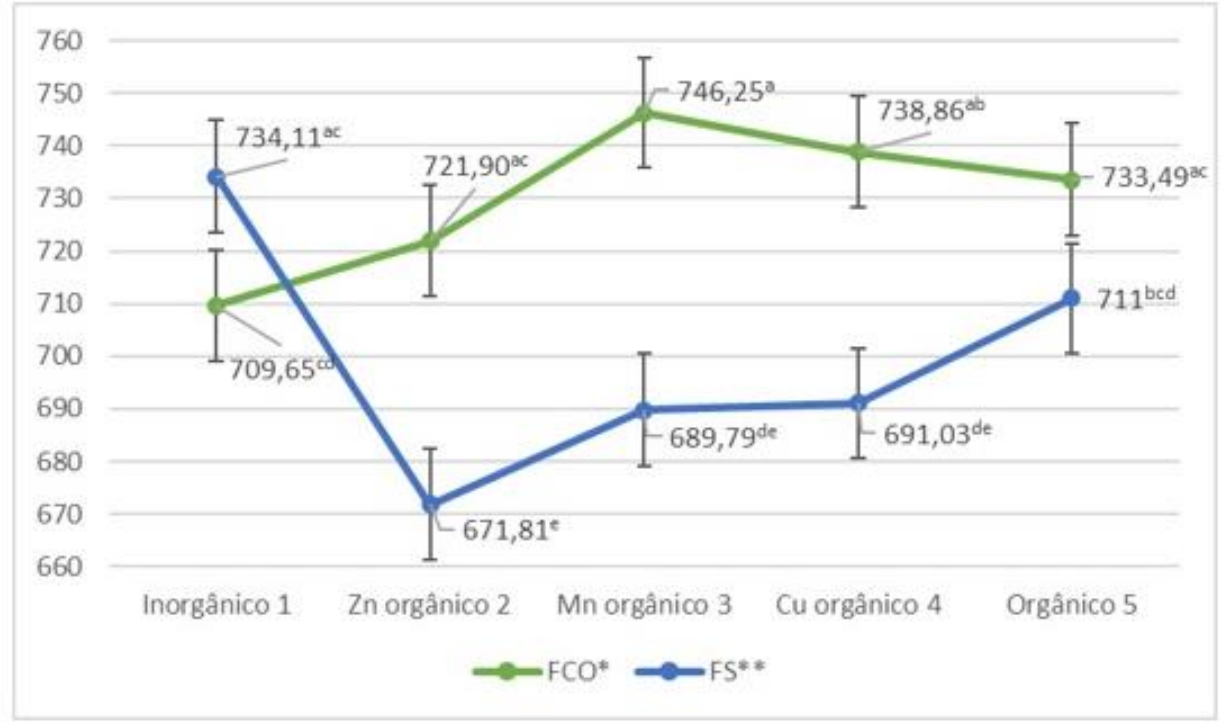

Fonte: Sarah Oliveira (2020).

${ }^{*} \mathrm{FCO}$ : farinha de carne e ossos; ${ }^{*} \mathrm{FS}$ : farelo de soja;

1Inorg: tratamento controle com as fontes de zinco, manganês e cobre apenas sob a forma inorgânica; ${ }^{2} \mathrm{Zn}$ org: zinco complexado com aminioácidos; ${ }^{3} \mathrm{Mn}$ org: manganês complexado com aminoácidos; ${ }^{4} \mathrm{Cu}$ org: cobre complexado com aminoácidos; ${ }^{5}$ Org: fontes de zinco, manganês e cobre complexados com aminoácidos.

Gráfico 2 - Interação do consumo de ração (g/ave) entre proteína e mineral na coleta 2 (60 dias) em poedeiras Dekalb White. São Paulo, 2020.

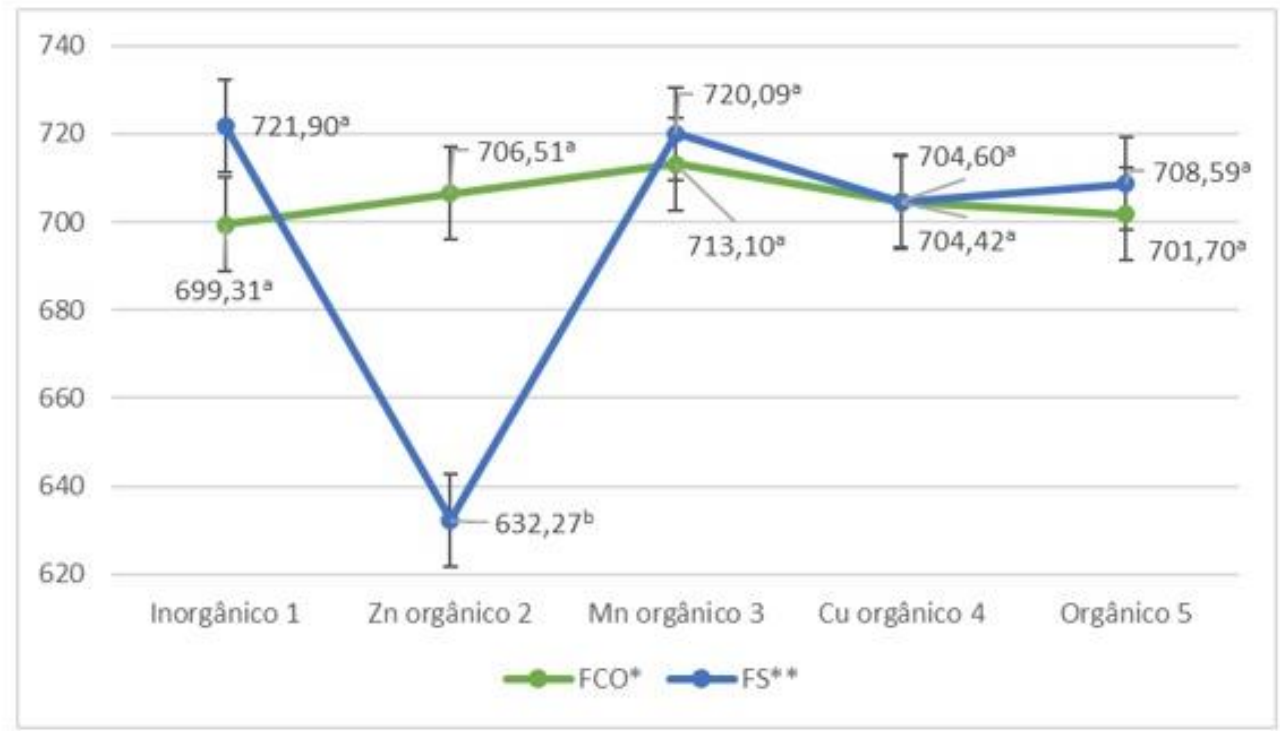

Fonte: Sarah Oliveira (2020).

*FCO: farinha de carne e ossos; **FS: farelo de soja;

${ }^{1}$ Inorg: tratamento controle com as fontes de zinco, manganês e cobre apenas sob a forma inorgânica; ${ }^{2} \mathrm{Zn}$ org: zinco complexado com aminioácidos; ${ }^{3} \mathrm{Mn}$ org: manganês complexado com aminoácidos; ${ }^{4} \mathrm{Cu}$ org: cobre complexado com aminoácidos; ${ }^{5} \mathrm{Org}$ : fontes de zinco, manganês e cobre complexados com aminoácidos. 
Gráfico 3 - Interação do consumo de ração médio (g/ave) entre proteína e mineral, durante todo o período experimental em poedeiras Dekalb White. São Paulo, 2020.

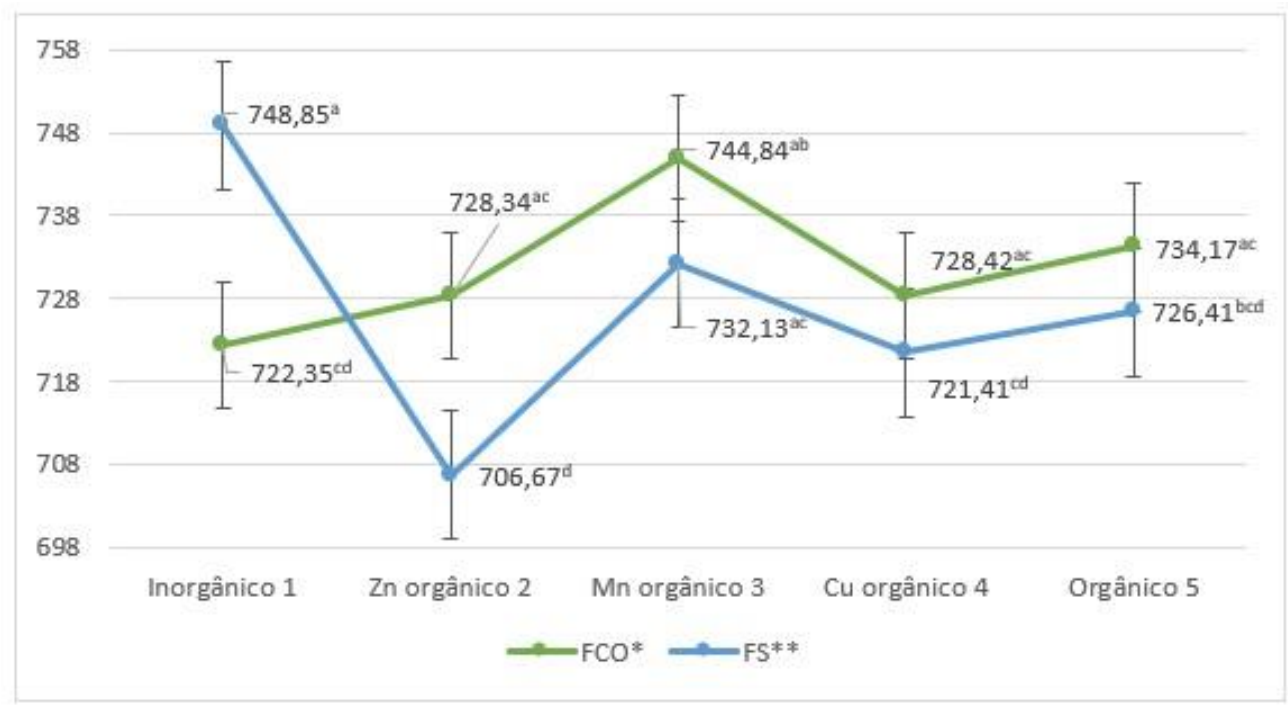

Fonte: Sarah Oliveira (2020).

${ }^{*} \mathrm{FCO}$ : farinha de carne e ossos; ${ }^{\star *} \mathrm{FS}$ : farelo de soja;

IInorg: tratamento controle com as fontes de zinco, manganês e cobre apenas sob a forma inorgânica; ${ }^{2} \mathrm{Zn}$ org: zinco complexado com aminioácidos; ${ }^{3} \mathrm{Mn}$ org: manganês complexado com aminoácidos; ${ }^{4} \mathrm{Cu}$ org: cobre complexado com aminoácidos; ${ }^{5}$ Org: fontes de zinco, manganês e cobre complexados com aminoácidos.

\subsubsection{Produção de ovo por ave}

A Tabela 5 mostra a média semanal da produção de ovos por ave durante o estudo, podemos notar que houve influência apenas do tempo $(P<0,0001)$ sobre o dado, sendo que houve diminuição na produção dos ovos com 0 avançar da idade das galinhas. Ao início do estudo a postura era em média de 6,68 ovos por semana, e ao final esse valor foi para 5,35 ovos por semana. 
Tabela 5 - Produção média de ovos por ave por semana em poedeiras Dekalb White, com idade inicial de 55 semanas que receberam $4 \%$ de farelo de carne e ossos (FCO) em substituição parcial ao farelo de soja e os elementos zinco, manganês e cobre isoladamente e associados na forma orgânica durante 42 semanas. São Paulo, 2020.

\begin{tabular}{|c|c|c|c|c|c|c|c|c|c|c|c|c|}
\hline \multirow{2}{*}{ Tempo } & \multicolumn{2}{|c|}{ Fonte de proteína } & \multicolumn{5}{|c|}{ Fonte de Mineral } & \multirow{2}{*}{ Média } & \multirow{2}{*}{ EPM } & \multicolumn{3}{|c|}{$\mathrm{P}$ valor } \\
\hline & $\mathrm{FCO}^{*}$ & $\mathrm{FS}^{* *}$ & $\operatorname{lnorg}^{1}$ & Zn org ${ }^{2}$ & Mn org ${ }^{3}$ & Cu org ${ }^{4}$ & $\mathrm{Org}^{5}$ & & & Proteína & Mineral & Proteína*mineral \\
\hline 0 dias & 6,6819 & 6,6864 & 6,7310 & 6,7130 & 6,6799 & 6,6241 & 6,6727 & $6,6841^{A}$ & 0,0550 & 0,9235 & 0,6434 & 0,1314 \\
\hline 60 dias & 6,4179 & 6,2391 & 6,4013 & 6,2772 & 6,4661 & 6,2339 & 6,2642 & $6,3285^{\mathrm{B}}$ & 0,0711 & 0,0804 & 0,5457 & 0,8928 \\
\hline 120 dias & 6,1128 & 6,0743 & 6,3172 & 6,0760 & 5,9766 & 6,2148 & 5,8831 & $5,7456^{c}$ & 0,0904 & 0,7989 & 0,3618 & 0,9992 \\
\hline 180 dias & 5,8542 & 5,6369 & 5,8128 & 5,7317 & 5,6499 & 5,7505 & 5,7829 & $5,7456^{\circ}$ & 0,1036 & 0,2334 & 0,9843 & 0,3741 \\
\hline 240 dias & 5,5035 & 5,4815 & 5,5753 & 5,4706 & 5,6757 & 5,6677 & 5,0732 & $5,4925^{E}$ & 0,1127 & 0,9139 & 0,3246 & 0,8912 \\
\hline 300 dias & 5,3397 & 5,3611 & 5,7077 & 5,3831 & 5,3516 & 5,4444 & 4,8650 & $5,3504^{\mathrm{E}}$ & 0,1133 & 0,9164 & 0,1403 & 0,1911 \\
\hline \multirow[t]{2}{*}{ Média } & 5,9850 & 5,9132 & 6,0909 & 5,9419 & 5,9666 & 5,9892 & 5,7568 & 5,9989 & 0,0339 & 0,5197 & 0,4333 & 0,7193 \\
\hline & \multicolumn{2}{|l|}{ P valor } & & & & & & & & & & \\
\hline Dias & & $<0,0001$ & & & & & & & & & & \\
\hline \multicolumn{2}{|c|}{ Proteína*Dias } & 0,3113 & & & & & & & & & & \\
\hline \multicolumn{2}{|c|}{ Mineral* Dias } & 0,3346 & & & & & & & & & & \\
\hline \multicolumn{2}{|c|}{ Proteina ${ }^{*}$ Mineral ${ }^{*}$ dias } & 0,6113 & & & & & & & & & & \\
\hline
\end{tabular}

Fonte: Sarah Oliveira (2020).

${ }^{*} \mathrm{FCO}$ : farinha de carne e ossos; **FS: farelo de soja;

IInorg: tratamento controle com as fontes de zinco, manganês e cobre apenas sob a forma inorgânica; ${ }^{2} \mathrm{Zn}$ org: zinco complexado com aminioácidos; ${ }^{3} \mathrm{Mn}$ org: manganês complexado com aminoácidos; ${ }^{4} \mathrm{Cu}$ org: cobre complexado com aminoácidos; ${ }^{5} \mathrm{Org}$ : fontes de zinco, manganês e cobre complexados com aminoácidos.

Letras maiúsculas diferentes na mesma coluna indicam diferença entre os momentos $(P<0,05)$.

\subsubsection{Conversão alimentar por dúzia}

A Tabela 6 nos mostra a conversão alimentar por dúzia de ovos em poedeiras durante os 10 meses do estudo. Houve interação mineral nos dias 240 e 300, nos quais observamos melhor conversão alimentar nas galinhas que receberam a associação dos elementos sob forma inorgânica em contraposição ao grupo que recebeu os elementos na forma orgânica que teve maior conversão. Os Gráficos 4 e 5 ilustram a interação proteína e mineral no dia 0 $(P=0,0439)$ e dia 60 ( $P<0,0001)$. No dia 0 o tratamento 8 (soja e manganês) obteve a melhor conversão alimentar contrastando com o tratamento 3 (FCO e manganês), enquanto no dia 60, o tratamento 7 (soja e zinco) foi o único que se distanciou dos outros, apresentando maior conversão alimentar. 
Tabela 6 - Conversão alimentar por dúzia de ovos produzida em poedeiras Dekalb White, com idade inicial de 55 semanas que receberam $4 \%$ de farelo de carne e ossos (FCO) em substituição parcial ao farelo de soja e os elementos zinco, manganês e cobre isoladamente e associados na forma orgânica durante 42 semanas. São Paulo, 2020.

\begin{tabular}{|c|c|c|c|c|c|c|c|c|c|c|c|c|}
\hline \multirow{2}{*}{ Tempo } & \multicolumn{2}{|c|}{ Fonte de proteína } & \multicolumn{5}{|c|}{ Fonte de Mineral } & \multirow{2}{*}{ Média } & \multirow{2}{*}{ EPM } & \multicolumn{3}{|c|}{ P valor } \\
\hline & $\mathrm{FCO}^{*}$ & $\mathrm{FS}^{* *}$ & $\operatorname{lnorg}^{1}$ & Zn org ${ }^{2}$ & Mn org ${ }^{3}$ & Cu org ${ }^{4}$ & Org $^{5}$ & & & Proteína & Mineral & Proteína*mineral \\
\hline 0 dias & 1,3439 & 1,2812 & 1,2997 & 1,2933 & 1,3107 & 1,3038 & 1,3550 & 1,3125 & 0,0277 & 0,0097 & 0,7140 & 0,0439 \\
\hline 60 dias & 1,2895 & 1,3476 & 1,2865 & 1,3882 & 1,2899 & 1,2855 & 1,3427 & 1,3185 & 0,0277 & 0,0184 & 0,0566 & $<0,0001$ \\
\hline 120 dias & 1,4537 & 1,4953 & 1,4225 & 1,5092 & 1,4739 & 1,4563 & 1,5105 & 1,4745 & 0,0278 & 0,2040 & 0,5962 & 0,4340 \\
\hline 180 dias & 1,5193 & 1,5543 & 1,4675 & 1,5786 & 1,5568 & 1,5141 & 1,5671 & 1,5368 & 0,0279 & 0,2902 & 0,6150 & 0,5520 \\
\hline 240 dias & 1,7211 & 1,8313 & $1,6437^{b}$ & $1,7227^{b}$ & $1,8206^{a b}$ & $1,7060^{b}$ & $1,9880^{a}$ & 1,7762 & 0,0282 & 0,1050 & 0,0028 & 0,2882 \\
\hline 300 dias & 1,8879 & 1,9120 & $1,7521^{\mathrm{c}}$ & $1,934^{b}$ & $1,8853^{b c}$ & $1,8589^{b c}$ & $2,0696^{a}$ & 1,9000 & 0,0285 & 0,4567 & 0,0165 & 0,0550 \\
\hline Média & 1,5359 & 1,5703 & 1,4787 & 1,5710 & 1,5562 & 1,5208 & 1,6388 & 1,5396 & 0,0123 & 0,3288 & 0,0895 & 0,4576 \\
\hline \multicolumn{3}{|c|}{ P valor } & & & & & & & & & & \\
\hline Dias & & $<0,0001$ & & & & & & & & & & \\
\hline \multicolumn{2}{|c|}{ Proteina*Dias } & $<0,0001$ & & & & & & & & & & \\
\hline \multicolumn{2}{|c|}{ Mineral*Dias } & 0,0011 & & & & & & & & & & \\
\hline \multicolumn{2}{|c|}{ Proteina ${ }^{*}$ Mineral ${ }^{*}$ dias } & $<0,0001$ & & & & & & & & & & \\
\hline
\end{tabular}

Fonte: Sarah Oliveira (2020).

${ }^{*}$ FCO: farinha de carne e ossos; **S: farelo de soja;

IInorg: tratamento controle com as fontes de zinco, manganês e cobre apenas sob a forma inorgânica; ${ }^{2} \mathrm{Zn}$ org: zinco complexado com aminioácidos; ${ }^{3} \mathrm{Mn}$ org: manganês complexado com aminoácidos; ${ }^{4} \mathrm{Cu}$ org: cobre complexado com aminoácidos; ${ }^{5} \mathrm{Org}$ : fontes de zinco, manganês e cobre complexados com aminoácidos.

Letras maiúsculas diferentes na mesma coluna indicam diferença entre os momentos $(P<0,05)$.

Gráfico 4 - Interação da conversão alimentar por dúzia entre proteína e mineral na coleta 1 (0 dias) em poedeiras Dekalb White. São Paulo, 2020.

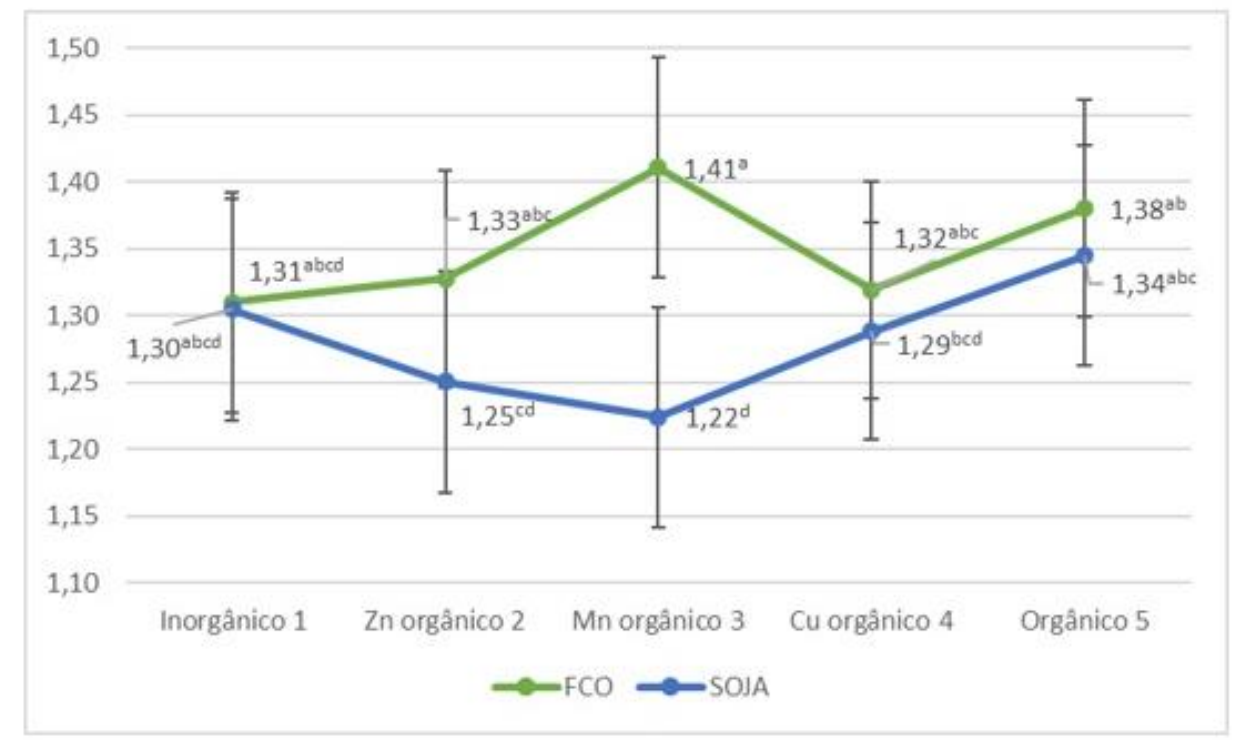

Fonte: Sarah Oliveira (2020).

${ }^{*} \mathrm{FCO}$ : farinha de carne e ossos; **FS: farelo de soja;

IInorg: tratamento controle com as fontes de zinco, manganês e cobre apenas sob a forma inorgânica; ${ }^{2} \mathrm{Zn}$ org: zinco complexado com aminioácidos; ${ }^{3} \mathrm{Mn}$ org: manganês complexado com aminoácidos; ${ }^{4} \mathrm{Cu}$ org: cobre complexado com aminoácidos; ${ }^{5} \mathrm{Org}$ : fontes de zinco, manganês e cobre complexados com aminoácidos. 
Gráfico 5 - Interação da conversão alimentar por dúzia entre proteína e mineral na coleta 2 (60 dias) em poedeiras Dekalb White. São Paulo, 2020.

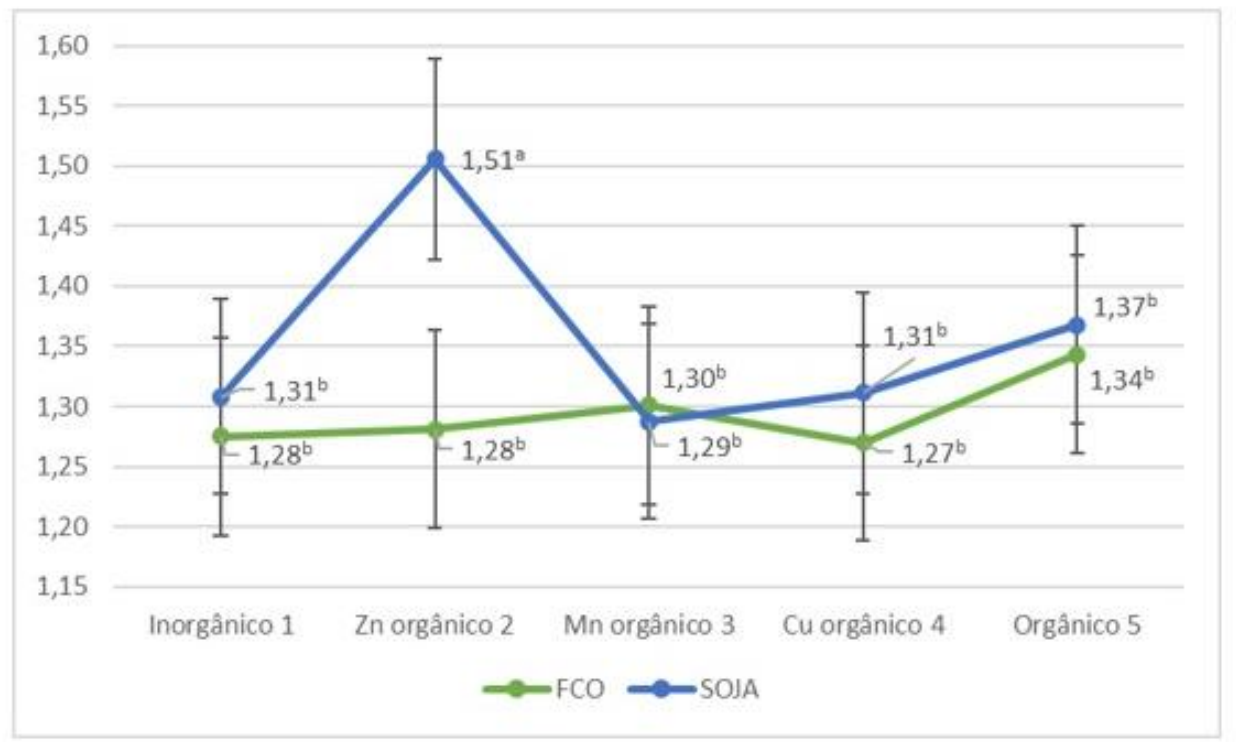

Fonte: Sarah Oliveira (2020).

${ }^{*} \mathrm{FCO}$ : farinha de carne e ossos; **FS: farelo de soja;

1'Inorg: tratamento controle com as fontes de zinco, manganês e cobre apenas sob a forma inorgânica; ${ }^{2} \mathrm{Zn}$ org: zinco complexado com aminioácidos; ${ }^{3} \mathrm{Mn}$ org: manganês complexado com aminoácidos; ${ }^{4} \mathrm{Cu}$ org: cobre complexado com aminoácidos; ${ }^{5} \mathrm{Org}$ : fontes de zinco, manganês e cobre complexados com aminoácidos.

\subsubsection{Peso do ovo}

A Tabela 7 mostra os valores de peso médio dos ovos durante 0 experimento. Em média geral, a fonte de proteína fez diferença $(P=0,0166)$, mas principalmente no final do estudo, isto é, nos dias $120(\mathrm{P}=0,0004), 180$ $(P=0,0021), 240(P=0,0443)$ e $300(P=0,0438)$, sendo que em todos o peso de ovos provenientes de tratamentos com soja superou aqueles com farinha de carne e osso. O gráfico 6 mostra a interação proteína e mineral no dia 60, revelando que o tratamento 7 , com zinco orgânico e farelo de soja como fonte exclusiva de proteína, determinou ovos mais leves em relação aos outros tratamentos. 
Tabela 7 - Peso dos ovos (g) em poedeiras Dekalb White, com idade inicial de 55 semanas que receberam $4 \%$ de farelo de carne e ossos (FCO) em substituição parcial ao farelo de soja e os elementos zinco, manganês e cobre isoladamente e associados na forma orgânica durante 42 semanas. São Paulo, 2020.

\begin{tabular}{|c|c|c|c|c|c|c|c|c|c|c|c|c|}
\hline \multirow{2}{*}{ Tempo } & \multicolumn{2}{|c|}{ Fonte de proteína } & \multicolumn{5}{|c|}{ Fonte de Mineral } & \multirow{2}{*}{ Média } & \multirow{2}{*}{ EPM } & \multicolumn{3}{|c|}{ Pvalor } \\
\hline & $\mathrm{FCO}^{*}$ & $\mathrm{FS}^{* *}$ & $\operatorname{lnorg}^{1}$ & Zn org ${ }^{2}$ & Mn org ${ }^{3}$ & Cu org ${ }^{4}$ & Org $^{5}$ & & & Proteína & Mineral & Proteina ${ }^{*}$ mineral \\
\hline 0 dias & 61,9375 & 2,1213 & 62,3148 & 61,4722 & 61,8377 & 62,5504 & 61,9719 & 62,0294 & 0,2204 & 0,6769 & 0,5776 & 0,8120 \\
\hline 60 dias & 61,6614 & 61,8498 & 62,0596 & 60,5519 & 62,0688 & 62,1135 & 61,9844 & 61,7556 & 0,1714 & 0,5831 & 0,0165 & 0,0023 \\
\hline 120 dias & 62,0153 & 63,3288 & 62,8269 & 62,3301 & 63,0193 & 62,6806 & 62,5033 & 62,6720 & 0,1816 & 0,0004 & 0,7800 & 0,8145 \\
\hline 180 dias & 63,8327 & 65,1650 & 64,7022 & 64,1805 & 64,5019 & 64,7786 & 64,3311 & 64,4989 & 0,2145 & 0,0021 & 0,8975 & 0,6581 \\
\hline 240 dias & 65,4026 & 66,3468 & 66,3441 & 65,6429 & 65,5290 & 66,3344 & 65,5231 & 65,8747 & 0,2334 & 0,0443 & 0,6135 & 0,4915 \\
\hline 300 dias & 65,5448 & 66,6055 & 66,8999 & 65,4319 & 66,0848 & 66,3983 & 65,5607 & 66,0751 & 0,2614 & 0,0438 & 0,3696 & 0,4867 \\
\hline Média & 63,3990 & 64,2362 & 64,1912 & 63,2682 & 63,8403 & 64,1426 & 63,6458 & 63,7434 & 0,0994 & 0,0166 & 0,4315 & 0,4472 \\
\hline
\end{tabular}

\begin{tabular}{lrc}
\hline Média & 63,3990 & 64,2362 \\
\hline \multicolumn{2}{c}{ P valor } \\
\hline Dias & $<0,0001$ \\
Proteínas*Dias & $<0,0001$ \\
Mineral*Dias & 0,0684 \\
Proteinas*Mineral*dias & $<0,0001$ \\
\hline
\end{tabular}

Fonte: Sarah Oliveira (2020).

*FCO: farinha de carne e ossos; **FS: farelo de soja;

IInorg: tratamento controle com as fontes de zinco, manganês e cobre apenas sob a forma inorgânica; ${ }^{2} \mathrm{Zn}$ org: zinco complexado com aminioácidos; ${ }^{3} \mathrm{Mn}$ org: manganês complexado com aminoácidos; ${ }^{4} \mathrm{Cu}$ org: cobre complexado com aminoácidos; ${ }^{5} \mathrm{Org}$ : fontes de zinco, manganês e cobre complexados com aminoácidos.

Gráfico 6 - Interação do peso dos ovos (g) entre proteína e mineral na coleta 2 (60 dias) em poedeiras Dekalb White. São Paulo, 2020.

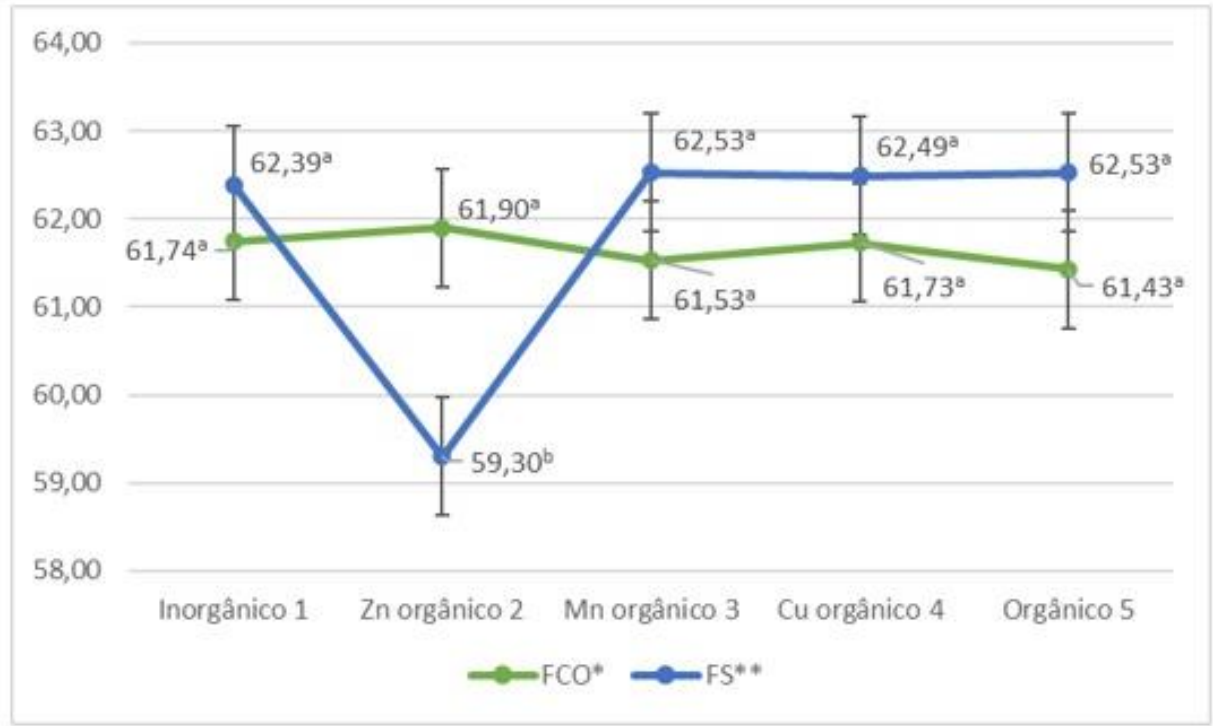

Fonte: Sarah Oliveira (2020).

${ }^{*} \mathrm{FCO}$ : farinha de carne e ossos; ${ }^{* *} \mathrm{FS}$ : farelo de soja;

IInorg: tratamento controle com as fontes de zinco, manganês e cobre apenas sob a forma inorgânica; ${ }^{2} \mathrm{Zn}$ org: zinco complexado com aminioácidos; ${ }^{3} \mathrm{Mn}$ org: manganês complexado com aminoácidos; ${ }^{4} \mathrm{Cu}$ org: cobre complexado com aminoácidos; ${ }^{5} \mathrm{Org}$ : fontes de zinco, manganês e cobre complexados com aminoácidos. 
4.3 Resultados da qualidade interna e externa do ovo

Na sequência serão apresentados os resultados obtidos, durante as 42 semanas do período experimental, em relação à qualidade dos ovos.

\subsubsection{Gravidade Específica}

A Tabela 8 mostra os valores médios para a densidade dos ovos durante o estudo. Pode-se observar que houve efeito de tempo $(P<0,0001)$, que promoveu, de maneira geral redução da gravidade específica com 0 envelhecimento das aves. Também foi observado que as poedeiras alimentadas com farelo de soja tiveram ovos com densidade maior do que as aves que tiveram substituição parcial por farinha de carne e ossos $(P=0,0415)$.

Tabela 8 - Gravidade específica dos ovos $\left(\mathrm{g} / \mathrm{cm}^{3}\right)$ em poedeiras Dekalb White, com idade inicial de 55 semanas que receberam $4 \%$ de farelo de carne e ossos (FCO) em substituição parcial ao farelo de soja e os elementos zinco, manganês e cobre isoladamente e associados na forma orgânica durante 42 semanas. São Paulo, 2020.

\begin{tabular}{|c|c|c|c|c|c|c|c|c|c|c|c|c|}
\hline \multirow{2}{*}{ Tempo } & \multicolumn{2}{|c|}{ Fonte de proteína } & \multicolumn{5}{|c|}{ Fonte de Mineral } & \multirow{2}{*}{ Média } & \multirow{2}{*}{ EPM } & \multicolumn{3}{|c|}{$P$ valor } \\
\hline & $\mathrm{FCO}^{*}$ & $\mathrm{FS}^{* *}$ & Inorg $^{1}$ & Zn org ${ }^{2}$ & Mn org ${ }^{3}$ & Cu org 4 & $\mathrm{Org}^{5}$ & & & Proteína & Mineral & Proteína*mineral \\
\hline 0 dias & 1,0912 & 1,0914 & 1,0917 & 1,0898 & 1,0915 & 1,0923 & 1,0915 & $1,0913^{A}$ & 0,0003 & 0,7691 & 0,1535 & 0,0487 \\
\hline 60 dias & 1,0879 & 1,0883 & 1,0881 & 1,0895 & 1,0876 & 1,0875 & 1,0879 & $1,0881^{B}$ & 0,0004 & 0,5873 & 0,4455 & 0,0550 \\
\hline 120 dias & 1,0872 & 1,0876 & 1,0880 & 1,0871 & 1,0874 & 1,0881 & 1,0861 & $1,0874^{B}$ & 0,0003 & 0,5700 & 0,3558 & 0,2618 \\
\hline 180 dias & 1,0842 & 1,0856 & 1,0845 & 1,0849 & 1,0834 & 1,0872 & 1,0844 & $1,0849^{c 0}$ & 0,0004 & 0,0845 & 0,0348 & 0,6989 \\
\hline 240 dias & 1,0831 & 1,0850 & 1,0844 & 1,0844 & 1,0829 & 1,084 & 1,0845 & $1,0840^{\circ}$ & 0,0004 & 0,0336 & 0,7513 & 0,9141 \\
\hline 300 dias & 1,0845 & 1,0858 & 1,0846 & 1,0856 & 1,0849 & 1,0855 & 1,0853 & $1,0852^{c}$ & 0,0004 & 0,1071 & 0,9211 & 0,0558 \\
\hline Média & 1,0864 & 1,0873 & 1,0869 & 1,0869 & 1,0863 & 1,0874 & 1,0866 & 1,0871 & 0,0002 & 0,0415 & 0,5716 & 0,2612 \\
\hline
\end{tabular}

P valor

\begin{tabular}{lc}
\hline Dias & $<0,0001$ \\
Proteina*Dias & 0,4236 \\
Mineral*Dias & 0,1007 \\
Proteina*Mineral*dias $^{*}$ & 0,2125 \\
\hline
\end{tabular}

Fonte: Sarah Oliveira (2020).

*FCO: farinha de carne e ossos; **FS: farelo de soja;

1'Inorg: tratamento controle com as fontes de zinco, manganês e cobre apenas sob a forma inorgânica; ${ }^{2} \mathrm{Zn}$ org: zinco complexado com aminioácidos; ${ }^{3} \mathrm{Mn}$ org: manganês complexado com aminoácidos; ${ }^{4} \mathrm{Cu}$ org: cobre complexado com aminoácidos; ${ }^{5} \mathrm{Org}$ : fontes de zinco, manganês e cobre complexados com aminoácidos.

Letras maiúsculas diferentes na mesma coluna indicam diferença entre os momentos $(P<0,05)$.

\subsubsection{Unidade Haugh}

A Tabela 9 mostra os valores da unidade Haugh, mensurados pelo Eggtester $^{\circledR}$ DET6000. Houve influência do tempo sobre os resultados 
$(P<0,0001)$, sendo que em linhas gerais houve diminuição dos valores da unidade Haugh com o tempo. Na tabela 9 também se observa o efeito médio da fonte de proteína ( $P=0,0404)$, na qual se nota que as poedeiras que receberam farelo de soja exclusivamente produziram ovos com maiores valores de Unidade Haugh em comparação com as recebera, $4 \%$ de farinha de carne e ossos.

Tabela 9 - Unidade Haugh dos ovos mensurada por meio do EggTester ${ }^{\circledR}$ DET6000, nos ovos produzidos por poedeiras Dekalb White, com idade inicial de 55 semanas que receberam 4\% de farelo de carne e ossos (FCO) em substituição parcial ao farelo de soja e os elementos zinco, manganês e cobre isoladamente e associados na forma orgânica durante 42 semanas. São Paulo, 2020.

\begin{tabular}{|c|c|c|c|c|c|c|c|c|c|c|c|c|}
\hline \multirow{2}{*}{ Tempo } & \multicolumn{2}{|c|}{ Fonte de proteina } & \multicolumn{5}{|c|}{ Fonte de Mineral } & \multirow{2}{*}{ Média } & \multirow{2}{*}{ EPM } & \multicolumn{3}{|c|}{ P valor } \\
\hline & $\mathrm{FCO}^{*}$ & $\mathrm{FS}^{* *}$ & Inorg $^{1}$ & Zn org ${ }^{2}$ & Mn org ${ }^{3}$ & Cu org ${ }^{4}$ & Org $^{5}$ & & & Proteina & Mineral & Proteina ${ }^{*}$ mineral \\
\hline 60 dias & 73,8403 & 75,9767 & 73,5228 & 73,9079 & 74,6245 & 76,7165 & 75,7707 & $74,9085^{c}$ & 1,3745 & 0,0237 & 0,1775 & 0,8131 \\
\hline 120 dias & 82,4254 & 83,2854 & 82,5899 & 83,3665 & 82,5567 & 83,3643 & 82,3996 & $82,8554^{A}$ & 1,3764 & 0,3657 & 0,9403 & 0,6508 \\
\hline 180 dias & 77,6078 & 79,6487 & 78,6218 & 78,8365 & 79,3847 & 79,3917 & 76,9066 & $78,6283^{B}$ & 1,4912 & 0,1727 & 0,8277 & 0,2517 \\
\hline 240 dias & 78,2391 & 77,7946 & 78,2108 & 77,7764 & 80,0136 & 77,7607 & 76,3227 & $78,0168^{B}$ & 1,3677 & 0,6204 & 0,1605 & 0,7321 \\
\hline 300 dias & 74,3723 & 75,3003 & 73,6004 & 76,7412 & 75,5419 & 73,7407 & 74,5572 & $74,8363^{c}$ & 1,4136 & 0,4190 & 0,3877 & 0,6769 \\
\hline Média & 77,2970 & 78,4011 & 77,3091 & 78,1257 & 78,4243 & 78,1948 & 77,1914 & 77,9580 & 0,2741 & 0,0404 & 0,4797 & 0,8485 \\
\hline \multicolumn{3}{|c|}{ P valor } & & & & & & & & & & \\
\hline Dias & & $<0,0001$ & & & & & & & & & & \\
\hline \multicolumn{2}{|c|}{ Proteína*Dias } & 0,2515 & & & & & & & & & & \\
\hline \multicolumn{2}{|c|}{ Mineral*Dias } & 0,2474 & & & & & & & & & & \\
\hline \multicolumn{2}{|c|}{ Proteina* Mineral ${ }^{*}$ dias } & 0,8756 & & & & & & & & & & \\
\hline
\end{tabular}

Fonte: Sarah Oliveira (2020).

*FCO: farinha de carne e ossos; **FS: farelo de soja;

1'Inorg: tratamento controle com as fontes de zinco, manganês e cobre apenas sob a forma inorgânica; ${ }^{2} \mathrm{Zn}$ org: zinco complexado com aminioácidos; ${ }^{3} \mathrm{Mn}$ org: manganês complexado com aminoácidos; ${ }^{4} \mathrm{Cu}$ org: cobre complexado com aminoácidos; ${ }^{5} \mathrm{Org}$ : fontes de zinco, manganês e cobre complexados com aminoácidos.

Letras maiúsculas diferentes na mesma coluna indicam diferença entre os momentos $(P<0,05)$.

\subsubsection{Altura do Albúmen}

$\mathrm{Na}$ Tabela 10 mostra os valores médios para a altura do albúmen dos ovos durante o experimento. $O$ tempo influenciou o dado $(P<0,0001)$ de modo que após ascensão inicial da altura do albúmen, seguiu-se queda com o avançar da idade das poedeiras.

Independentemente do tempo e da fonte de mineral, a média geral da altura do albúmen foi influenciada pela fonte de proteína $(P=0,0240)$, onde aves alimentadas exclusivamente com farelo de soja tiveram seus ovos com altura de albúmen superior àquelas alimentadas com $4 \%$ de farinha de carne e ossos. 
Tabela 10 - Valores para a altura do albúmen dos ovos $(\mathrm{mm})$, mensurados por meio do EggTester ${ }^{\circledR}$ DET6000, nos ovos produzidos por poedeiras Dekalb White, com idade inicial de 55 semanas que receberam $4 \%$ de farelo de carne e ossos (FCO) em substituição parcial ao farelo de soja e os elementos zinco, manganês e cobre isoladamente e associados na forma orgânica durante 42 semanas. São Paulo, 2020.

\begin{tabular}{|c|c|c|c|c|c|c|c|c|c|c|c|c|}
\hline \multirow{2}{*}{ Tempo } & \multicolumn{2}{|c|}{ Fonte de proteína } & \multicolumn{5}{|c|}{ Fonte de Mineral } & \multirow{2}{*}{ Média } & \multirow{2}{*}{ EPM } & \multicolumn{3}{|c|}{ P valor } \\
\hline & $\mathrm{FCO}^{*}$ & $\mathrm{FS}^{* *}$ & $\operatorname{lnorg}^{1}$ & Zn org ${ }^{2}$ & $\mathrm{Mn}_{\mathrm{org}}{ }^{3}$ & $\mathrm{Cu}$ org $^{4}$ & $\mathrm{Org}^{5}$ & & & Proteína & Mineral & Proteína*mineral \\
\hline 60 dias & 5,7296 & 6,0435 & 5,7628 & 5,8062 & 5,8278 & 6,0335 & 6,0027 & $5,8866^{\circ}$ & 0,1339 & 0,0076 & 0,4649 & 0,8163 \\
\hline 120 dias & 7,0098 & 7,2117 & 7,0392 & 7,2092 & 7,1582 & 7,2773 & 6,8698 & $7,1107^{A}$ & 0,1397 & 0,1548 & 0,4039 & 0,2715 \\
\hline 180 dias & 7,0750 & 7,3226 & 7,0542 & 7,2318 & 7,3563 & 7,5601 & 6,7917 & $7,1988^{A}$ & 0,1570 & 0,2200 & 0,1541 & 0,2969 \\
\hline 240 dias & 6,4764 & 6,4685 & 6,5201 & 6,4297 & 6,7062 & 6,4397 & 6,2664 & $6,4724^{8}$ & 0,1361 & 0,9500 & 0,3005 & 0,6603 \\
\hline 300 dias & 6,0680 & 6,1702 & 6,0433 & 6,2906 & 6,1540 & 6,0036 & 6,1041 & $6,1191^{\mathrm{C}}$ & 0,1409 & 0,4842 & 0,7619 & 0,6498 \\
\hline Média & 6,4718 & 6,6433 & 6,4839 & 6,5935 & 6,6405 & 6,6628 & 6,4069 & 6,5640 & 0,0382 & 0,0240 & 0,1617 & 0,8003 \\
\hline \multicolumn{3}{|c|}{$P$ valor } & & & & & & & & & & \\
\hline Dias & & $<0,0001$ & & & & & & & & & & \\
\hline Proteína & & 0,4021 & & & & & & & & & & \\
\hline Mineral* & & 0,2363 & & & & & & & & & & \\
\hline Proteína & neral ${ }^{*}$ dias & 0,5892 & & & & & & & & & & \\
\hline
\end{tabular}

Fonte: Sarah Oliveira (2020).

${ }^{*} \mathrm{FCO}$ : farinha de carne e ossos; **FS: farelo de soja;

${ }^{1}$ Inorg: tratamento controle com as fontes de zinco, manganês e cobre apenas sob a forma inorgânica; ${ }^{2} \mathrm{Zn}$ org: zinco complexado com aminioácidos; ${ }^{3} \mathrm{Mn}$ org: manganês complexado com aminoácidos; ${ }^{4} \mathrm{Cu}$ org: cobre complexado com aminoácidos; ${ }^{5} \mathrm{Org}$ : fontes de zinco, manganês e cobre complexados com aminoácidos.

Letras maiúsculas diferentes na mesma coluna indicam diferença entre os momentos $(P<0,05)$.

\subsubsection{Cor da gema}

As Tabelas 11 e 12 mostram os valores médios para a cor da gema, mensuradas por meio da colorimetria manualmente e pelo Eggtester ${ }^{\circledR}$ DET6000, respectivamente. Em ambas as tabelas se nota que o tempo influenciou na cor da gema $(P<0,0001)$, sendo que ao final do estudo, nos dois métodos, a gema se apresentou com amarelo mais intenso em comparação ao início. Na Tabela 11 os valores médios para a cor da gema foram influenciados pela fonte de proteína $(P=0,0017)$ e poedeiras que receberam farinha de carne e ossos apresentaram gemas mais escuras do que as suplementadas exclusivamente com farelo de soja. A Tabela 12 também demonstrou resultados semelhantes na média da fonte de proteína e nos dias 0,60, 120, 180 e $300(P<0,0001)$. 
Tabela 11 - Cor da gema mensurada por meio do Youlk Colour Fan nos ovos produzidos por poedeiras Dekalb White, com idade inicial de 55 semanas que receberam $4 \%$ de farelo de carne e ossos (FCO) em substituição parcial ao farelo de soja e os elementos zinco, manganês e cobre isoladamente e associados na forma orgânica durante 42 semanas. São Paulo, 2020.

\begin{tabular}{|c|c|c|c|c|c|c|c|c|c|c|c|c|}
\hline \multirow{2}{*}{ Tempo } & \multicolumn{2}{|c|}{ Fonte de proteína } & \multicolumn{5}{|c|}{ Fonte de Mineral } & \multirow{2}{*}{ Média } & \multirow{2}{*}{ EPM } & \multicolumn{3}{|c|}{$P$ valor } \\
\hline & $\mathrm{FCO}^{*}$ & $\mathrm{FS}^{* *}$ & Inorg $^{1}$ & Zn org ${ }^{2}$ & Mn org ${ }^{3}$ & Cu org ${ }^{4}$ & Org $^{5}$ & & & Proteína & Mineral & Proteína*mineral \\
\hline 0 dias & 6,4496 & 6,4833 & 6,4792 & 6,5072 & 6,3333 & 6,5000 & 6,5127 & $6,4665^{\mathrm{c}}$ & 0,0836 & 0,8112 & 0,9209 & 0,6251 \\
\hline 60 dias & 6,7677 & 6,6234 & 6,7177 & 6,8333 & 6,6987 & 6,7593 & 6,4689 & $6,6956^{\mathrm{B}}$ & 0,0624 & 0,0965 & 0,0946 & 0,1901 \\
\hline 120 dias & 5,8166 & 5,6702 & 5,5593 & 6,0751 & 5,8181 & 5,6372 & 5,6275 & $5,7434^{\circ}$ & 0,0785 & 0,2569 & 0,0869 & 0,5407 \\
\hline 180 dias & 6,0017 & 5,5999 & 5,9252 & 5,5934 & 5,8831 & 5,7879 & 5,8143 & $5,8008^{\circ}$ & 0,0760 & 0,0012 & 0,4894 & 0,0145 \\
\hline 240 dias & 7,1820 & 7,0112 & 7,2551 & 7,0482 & 6,9700 & 7,2557 & 6,9541 & $7,0966^{A}$ & 0,0657 & 0,0759 & 0,1020 & 0,8753 \\
\hline 300 dias & 6,9775 & 6,9511 & 6,9664 & 6,9813 & 7,0784 & 6,9426 & 6,8528 & $6,9643^{A}$ & 0,0589 & 0,7289 & 0,4811 & 0,8043 \\
\hline Média & 6,5325 & 6,3899 & 6,4838 & 6,5064 & 6,4636 & 6,3717 & 6,3748 & 6,4412 & 0,0277 & 0,0017 & 0,3813 & 0,8278 \\
\hline \multicolumn{3}{|c|}{ P valor } & & & & & & & & & & \\
\hline Dias & & $<0,0001$ & & & & & & & & & & \\
\hline Proteina* & & 0,1425 & & & & & & & & & & \\
\hline Mineral* & & 0,2514 & & & & & & & & & & \\
\hline Proteína* & neral ${ }^{*}$ dias & 0,1509 & & & & & & & & & & \\
\hline
\end{tabular}

Fonte: Sarah Oliveira (2020).

${ }^{*} \mathrm{FCO}$ : farinha de carne e ossos; **FS: farelo de soja;

IInorg: tratamento controle com as fontes de zinco, manganês e cobre apenas sob a forma inorgânica; ${ }^{2} \mathrm{Zn}$ org: zinco complexado com aminioácidos; ${ }^{3} \mathrm{Mn}$ org: manganês complexado com aminoácidos; ${ }^{4} \mathrm{Cu}$ org: cobre complexado com aminoácidos; ${ }^{5} \mathrm{Org}$ : fontes de zinco, manganês e cobre complexados com aminoácidos.

Letras maiúsculas diferentes na mesma coluna indicam diferença entre os momentos $(P<0,05)$.

Tabela 12 - Cor da gema mensurada por meio do EggTester ${ }^{\circledR}$ DET6000 nos ovos produzidos por poedeiras Dekalb White, com idade inicial de 55 semanas que receberam $4 \%$ de farelo de carne e ossos (FCO) em substituição parcial ao farelo de soja e os elementos zinco, manganês e cobre isoladamente e associados na forma orgânica durante 42 semanas. São Paulo, 2020.

\begin{tabular}{|c|c|c|c|c|c|c|c|c|c|c|c|c|}
\hline \multirow{2}{*}{ Tempo } & \multicolumn{2}{|c|}{ Fonte de proteína } & \multicolumn{5}{|c|}{ Fonte de Mineral } & \multirow{2}{*}{ Média } & \multirow{2}{*}{ EPM } & \multicolumn{3}{|c|}{ P valor } \\
\hline & $\mathrm{FCO}^{*}$ & $\mathrm{FS}^{* *}$ & Inorg $^{1}$ & $\mathrm{Zn}$ org ${ }^{2}$ & Mn org ${ }^{3}$ & Cu org 4 & Org $^{5}$ & & & Proteína & Mineral & Proteina*mineral \\
\hline 60 dias & 6,6676 & 6,3888 & 6,6227 & 6,5711 & 6,4546 & 6,5258 & 6,4668 & 6,5282 & 0,0304 & $<0,0001$ & 0,2593 & 0,1059 \\
\hline 120 dias & 5,2190 & 4,9298 & 5,0062 & 5,3532 & 4,9898 & 5,0428 & 4,9799 & 5,0744 & 0,0366 & $<0,0001$ & 0,0100 & 0,1451 \\
\hline 180 dias & 4,5895 & 4,2751 & 4,4623 & 4,3905 & 4,3643 & 4,4900 & 4,4544 & 4,4323 & 0,0335 & $<0,0001$ & 0,6812 & 0,4292 \\
\hline 240 dias & 6,8682 & 6,7456 & 6,8156 & 6,7514 & 6,8108 & 6,7471 & 6,9096 & 6,8069 & 0,0356 & 0,0577 & 0,6010 & 0,5154 \\
\hline 300 dias & 6,9003 & 6,5932 & 6,7327 & 6,7628 & 6,7984 & 6,7366 & 6,7032 & 6,7467 & 0,0352 & $<0,0001$ & 0,9253 & 0,5755 \\
\hline Média & 6,0489 & 5,7865 & 5,9279 & 5,9658 & 5,8836 & 5,9085 & 5,9027 & 5,8914 & 0,0336 & $<0,0001$ & 0,4943 & 0,4943 \\
\hline \multicolumn{3}{|c|}{$\mathrm{P}$ valor } & & & & & & & & & & \\
\hline Dias & & $<0,0001$ & & & & & & & & & & \\
\hline Proteína & & 0,0295 & & & & & & & & & & $\begin{array}{l}1 \\
1\end{array}$ \\
\hline Mineral* & & 0,1020 & & & & & & & & & & \\
\hline Proteína & neral ${ }^{*}$ dias & 0,2334 & & & & & & & & & & \\
\hline
\end{tabular}

Fonte: Sarah Oliveira (2020).

${ }^{*} \mathrm{FCO}$ : farinha de carne e ossos; ${ }^{* *} \mathrm{FS}$ : farelo de soja;

IInorg: tratamento controle com as fontes de zinco, manganês e cobre apenas sob a forma inorgânica; ${ }^{2} \mathrm{Zn}$ org: zinco complexado com aminioácidos; ${ }^{3} \mathrm{Mn}$ org: manganês complexado com aminoácidos; ${ }^{4} \mathrm{Cu}$ org: cobre complexado com aminoácidos; ${ }^{5} \mathrm{Org}$ : fontes de zinco, manganês e cobre complexados com aminoácidos. 


\subsubsection{Espessura da casca}

Os valores médios para a espessura da casca dos ovos são apresentados na Tabela 13. Só foi observado efeito de tempo sobre essa variável, $(P<0,0001)$, que se tornou menor quanto maior a idade da ave e teve o menor valor de espessura aos 180 dias do período experimental.

Tabela 13 - Espessura da casca dos ovos $(\mathrm{mm})$ dos ovos produzidos por poedeiras Dekalb White, com idade inicial de 55 semanas que receberam $4 \%$ de farelo de carne e ossos (FCO) em substituição parcial ao farelo de soja e os elementos zinco, manganês e cobre isoladamente e associados na forma orgânica durante 42 semanas. São Paulo, 2020.

\begin{tabular}{|c|c|c|c|c|c|c|c|c|c|c|c|c|}
\hline \multirow{2}{*}{ Tempo } & \multicolumn{2}{|c|}{ Fonte de proteína } & \multicolumn{5}{|c|}{ Fonte de Mineral } & \multirow{2}{*}{ Média } & \multirow{2}{*}{ EPM } & \multicolumn{3}{|c|}{$\mathrm{P}$ valor } \\
\hline & $\mathrm{FCO}^{*}$ & $\mathrm{FS}^{* *}$ & $\operatorname{lnorg}^{1}$ & Zn org ${ }^{2}$ & $\mathrm{Mn} \mathrm{org}^{3}$ & Cu org ${ }^{4}$ & Org $^{5}$ & & & Proteína & Mineral & Proteína*mineral \\
\hline 0 dias & 0,4457 & 0,4401 & 0,4454 & 0,4352 & 0,4451 & 0,4465 & 0,4426 & $0,4429^{8}$ & 0,0052 & 0,2625 & 0,5748 & 0,5848 \\
\hline 60 dias & 0,4243 & 0,4237 & 0,4220 & 0,4280 & 0,4233 & 0,4195 & 0,4271 & $0,424^{c}$ & 0,0052 & 0,9381 & 0,6592 & 0,2390 \\
\hline 120 dias & 0,4559 & 0,4611 & 0,4601 & 0,4538 & 0,4590 & 0,4697 & 0,4497 & $0,4585^{A}$ & 0,0053 & 0,5270 & 0,3028 & 0,3554 \\
\hline 180 dias & 0,4095 & 0,4186 & 0,4131 & 0,4131 & 0,4079 & 0,4321 & 0,4041 & $0,414^{\circ}$ & 0,0053 & 0,0417 & 0,0007 & 0,6385 \\
\hline 240 dias & 0,4232 & 0,4284 & 0,4261 & 0,4254 & 0,4202 & 0,4296 & 0,4278 & $0,4258^{c}$ & 0,0053 & 0,2741 & 0,7881 & 0,9975 \\
\hline 300 dias & 0,4248 & 0,4243 & 0,4241 & 0,4318 & 0,4199 & 0,4273 & 0,4197 & $0,4246^{c}$ & 0,0054 & 0,8472 & 0,5180 & 0,8582 \\
\hline Média & 0,4306 & 0,4327 & 0,4318 & 0,4312 & 0,4292 & 0,4374 & 0,4285 & 0,4324 & 0,0011 & 0,3751 & 0,2658 & 0,6866 \\
\hline \multicolumn{3}{|c|}{ P valor } & & & & & & & & & & \\
\hline Dias & & $<0,0001$ & & & & & & & & & & \\
\hline Proteína & & 0,2001 & & & & & & & & & & \\
\hline Mineral* & & 0,0547 & & & & & & & & & & \\
\hline Proteína & neral ${ }^{*}$ dias & 0,9148 & & & & & & & & & & \\
\hline
\end{tabular}

Fonte: Sarah Oliveira (2020).

*FCO: farinha de carne e ossos; **FS: farelo de soja;

${ }^{1}$ Inorg: tratamento controle com as fontes de zinco, manganês e cobre apenas sob a forma inorgânica; ${ }^{2} \mathrm{Zn}$ org: zinco complexado com aminioácidos; ${ }^{3} \mathrm{Mn}$ org: manganês complexado com aminoácidos; ${ }^{4} \mathrm{Cu}$ org: cobre complexado com aminoácidos; ${ }^{5} \mathrm{Org}$ : fontes de zinco, manganês e cobre complexados com aminoácidos.

Letras maiúsculas diferentes na mesma coluna indicam diferença entre os momentos $(P<0,05)$.

\subsubsection{Porcentagem da casca}

Os dados de porcentagem de casca podem ser observados na Tabela 14. Só houve efeito de tempo para essa variável $(P<0,0001)$, demonstrando a redução na porcentagem da casca dos ovos com o avançar da idade das poedeiras. 
Tabela 14 - Porcentagem de casca (\%) nos ovos produzidos por poedeiras Dekalb White, com idade inicial de 55 semanas que receberam $4 \%$ de farelo de carne e ossos (FCO) em substituição parcial ao farelo de soja e os elementos zinco, manganês e cobre isoladamente e associados na forma orgânica durante 42 semanas. São Paulo, 2020.

\begin{tabular}{|c|c|c|c|c|c|c|c|c|c|c|c|c|}
\hline \multirow{2}{*}{ Tempo } & \multicolumn{2}{|c|}{ Fonte de proteína } & \multicolumn{5}{|c|}{ Fonte de Mineral } & \multirow{2}{*}{ Média } & \multirow{2}{*}{ EPM } & \multicolumn{3}{|c|}{$\mathrm{P}$ valor } \\
\hline & $\mathrm{FCO}^{*}$ & $\mathrm{FS}^{* *}$ & $\operatorname{lnorg}^{1}$ & Zn org ${ }^{2}$ & Mn org ${ }^{3}$ & Cu org ${ }^{4}$ & $\mathrm{Org}^{5}$ & & & Proteína & Mineral & Proteína*mineral \\
\hline 0 dias & 9,8124 & 9,7968 & 9,8792 & 9,7212 & 9,6708 & 9,9108 & 9,8408 & $9,8046^{A}$ & 0,0494 & 0,8744 & 0,4743 & 0,0723 \\
\hline 60 dias & 9,4452 & 9,4570 & 9,4983 & 9,5836 & 9,3701 & 9,3202 & 9,4833 & $9,4511^{c}$ & 0,0469 & 0,8995 & 0,4060 & 0,3594 \\
\hline 120 dias & 9,6445 & 9,6589 & 9,7524 & 9,5824 & 9,7227 & 9,7178 & 9,4832 & $9,6517^{\mathrm{B}}$ & 0,0452 & 0,8732 & 0,2715 & 0,1813 \\
\hline 180 dias & 9,1978 & 9,4128 & 9,1759 & 9,3478 & 9,1185 & 9,6812 & 9,2031 & $9,3053^{\circ}$ & 0,0555 & 0,0541 & 0,0094 & 0,7563 \\
\hline 240 dias & 8,9666 & 9,2344 & 9,1458 & 9,1520 & 8,9100 & 9,1357 & 9,1589 & $9,1005^{\mathrm{E}}$ & 0,0620 & 0,0319 & 0,6767 & 0,5810 \\
\hline 300 dias & 8,6161 & 8,8193 & 8,7855 & 8,7157 & 8,6517 & 8,7811 & 8,6547 & $8,7177^{F}$ & 0,0714 & 0,1564 & 0,9557 & 0,2500 \\
\hline Média & 9,2804 & 9,3965 & 9,3728 & 9,3504 & 9,2406 & 9,4245 & 9,3040 & 9,3825 & 0,0242 & 0,0693 & 0,4249 & 0,5746 \\
\hline
\end{tabular}

P valor

\begin{tabular}{lc}
\hline Dias & $<0,0001$ \\
Proteína*Dias & 0,2235 \\
Mineral*Dias $^{*}$ & 0,0929 \\
Proteina*Mineral*dias $^{*}$ & 0,4234 \\
\hline
\end{tabular}

Fonte: Sarah Oliveira (2020).

${ }^{*} \mathrm{FCO}$ : farinha de carne e ossos; ${ }^{* *} \mathrm{FS}$ : farelo de soja;

IInorg: tratamento controle com as fontes de zinco, manganês e cobre apenas sob a forma inorgânica; ${ }^{2} \mathrm{Zn}$ org: zinco complexado com aminioácidos; ${ }^{3} \mathrm{Mn}$ org: manganês complexado com aminoácidos; ${ }^{4} \mathrm{Cu}$ org: cobre complexado com aminoácidos; ${ }^{5} \mathrm{Org}$ : fontes de zinco, manganês e cobre complexados com aminoácidos.

Letras maiúsculas diferentes na mesma coluna indicam diferença entre os momentos $(P<0,05)$.

\subsubsection{Resistência da casca}

Na Tabela 15 são demonstrados os valores médios para a resistência da casca em quilograma-força. Foi observado apenas efeito do tempo, que conforme progrediu a idade das aves, houve redução da resistência da casca dos ovos, independente do tratamento recebido $(P<0,0001)$. 
Tabela 15 - Valores médios para resistência da casca $(\mathrm{kfg})$, mensurados por meio EggTester ${ }^{\circledR}$ DET6000, dos ovos produzidos por poedeiras Dekalb White, com idade inicial de 55 semanas que receberam $4 \%$ de farelo de carne e ossos (FCO) em substituição parcial ao farelo de soja e os elementos zinco, manganês e cobre isoladamente e associados na forma orgânica durante 42 semanas. São Paulo, 2020.

\begin{tabular}{|c|c|c|c|c|c|c|c|c|c|c|c|c|}
\hline \multirow{2}{*}{ Tempo } & \multicolumn{2}{|c|}{ Fonte de proteína } & \multicolumn{5}{|c|}{ Fonte de Mineral } & \multirow{2}{*}{ Média } & \multirow{2}{*}{ EPM } & \multicolumn{3}{|c|}{$P$ valor } \\
\hline & $\mathrm{FCO}^{*}$ & $\mathrm{FS}^{* *}$ & $\operatorname{lnorg}^{1}$ & Zn org ${ }^{2}$ & $\mathrm{Mn}$ org $^{3}$ & Cu org ${ }^{4}$ & Org $^{5}$ & & & Proteína & Mineral & Proteína*mineral \\
\hline 60 dias & 4,2724 & 4,3336 & 4,4745 & 4,3192 & 4,1245 & 4,4206 & 4,1761 & $4,3030^{A}$ & 0,0538 & 0,4848 & 0,0462 & 0,0091 \\
\hline 120 dias & 3,9994 & 4,1662 & 4,2503 & 4,0811 & 4,0041 & 4,0507 & 4,0280 & $4,0828^{B A}$ & 0,0529 & 0,0518 & 0,3557 & 0,2821 \\
\hline 180 dias & 3,8548 & 3,9157 & 3,7752 & 4,0065 & 3,7678 & 3,9606 & 3,9160 & $3,8852^{\mathrm{B}}$ & 0,0542 & 0,4911 & 0,3044 & 0,7297 \\
\hline 240 dias & 3,3731 & 4,1684 & 3,5398 & 3,3352 & 3,3346 & 3,4860 & 5,1578 & $3,7708^{8}$ & 0,3293 & 0,2260 & 0,3497 & 0,3715 \\
\hline 300 dias & 3,1495 & 3,2805 & 3,1007 & 3,1754 & 3,1027 & 3,4852 & 3,2111 & $3,2150^{c}$ & 0,0610 & 0,2121 & 0,1138 & 0,0568 \\
\hline Média & 3,7298 & 3,9729 & 3,8281 & 3,7835 & 3,6667 & 3,8806 & 4,0978 & 3,8682 & 0,0672 & 0,0670 & 0,3436 & 0,4321 \\
\hline \multicolumn{3}{|c|}{ P valor } & & & & & & & & & & \\
\hline Dias & & $<0,0001$ & & & & & & & & & & \\
\hline Proteína & & 0,6704 & & & & & & & & & & \\
\hline Mineral* & & 0,1670 & & & & & & & & & & \\
\hline Proteína* & heral ${ }^{*}$ dias & 0,0612 & & & & & & & & & & \\
\hline
\end{tabular}

Fonte: Sarah Oliveira (2020).

*FCO: farinha de carne e ossos; **FS: farelo de soja;

1'Inorg: tratamento controle com as fontes de zinco, manganês e cobre apenas sob a forma inorgânica; ${ }^{2} \mathrm{Zn}$ org: zinco complexado com aminioácidos; ${ }^{3} \mathrm{Mn}$ org: manganês complexado com aminoácidos; ${ }^{4} \mathrm{Cu}$ org: cobre complexado com aminoácidos; ${ }^{5} \mathrm{Org}$ : fontes de zinco, manganês e cobre complexados com aminoácidos.

Letras maiúsculas diferentes na mesma coluna indicam diferença entre os momentos $(P<0,05)$.

\subsubsection{Classificação do ovo}

A classificação dos ovos foi feita por meio do equipamento Eggtester ${ }^{\circledR}$ DET6000 e pode ser observada na Tabela 16. Foi observado efeito de tempo $(<0,0001)$, apontando para menor qualidade dos ovos nos dias 60 e 300 . 
Tabela 16 - Valores médios para a classificação dos ovos, mensurados por meio do EggTester ${ }^{\circledR}$ DET6000, produzidos por poedeiras Dekalb White, com idade inicial de 55 semanas que receberam $4 \%$ de farelo de carne e ossos (FCO) em substituição parcial ao farelo de soja e os elementos zinco, manganês e cobre isoladamente e associados na forma orgânica durante 42 semanas. São Paulo, 2020.

\begin{tabular}{|c|c|c|c|c|c|c|c|c|c|c|c|c|}
\hline \multirow{2}{*}{ Tempo } & \multicolumn{2}{|c|}{ Fonte de proteína } & \multicolumn{5}{|c|}{ Fonte de Mineral } & \multirow{2}{*}{ Média } & \multirow{2}{*}{ EPM } & \multicolumn{3}{|c|}{ Pvalor } \\
\hline & $\mathrm{FCO}^{*}$ & $\mathrm{FS}^{* *}$ & Inorg $^{1}$ & Zn org ${ }^{2}$ & Mn org ${ }^{3}$ & $\mathrm{Cu}$ org $^{4}$ & Org $^{5}$ & & & Proteína & Mineral & Proteína*mineral \\
\hline 60 dias & 1,4484 & 1,3486 & 1,4144 & 1,4865 & 1,4991 & 1,2714 & 1,3212 & $1,3985^{A}$ & 0,0332 & 0,1923 & 0,1162 & 0,7935 \\
\hline 120 dias & 1,0483 & 1,0681 & 1,0880 & 1,0483 & 1,0713 & 1,049 & 1,0344 & $1,0582^{c}$ & 0,0113 & 0,3860 & 0,5613 & 0,5031 \\
\hline 180 dias & 1,1478 & 1,0908 & 1,2505 & 1,0963 & 1,0847 & 1,0346 & 1,1304 & $1,1193^{c}$ & 0,0180 & 0,1533 & 0,0054 & 0,1994 \\
\hline 240 dias & 1,2087 & 1,2582 & 1,2345 & 1,2939 & 1,1618 & 1,2758 & 1,2013 & $1,2335^{\mathrm{B}}$ & 0,0295 & 0,4647 & 0,6324 & 0,8952 \\
\hline 300 dias & 1,4739 & 1,3859 & 1,4796 & 1,4018 & 1,3765 & 1,4435 & 1,4483 & $1,4299^{4}$ & 0,0371 & 0,2364 & 0,9254 & 0,4946 \\
\hline Média & 1,2654 & 1,2303 & 1,2934 & 1,2653 & 1,2387 & 1,2149 & 1,2271 & 1,2481 & 0,0130 & 0,2807 & 0,2807 & 0,8286 \\
\hline \multicolumn{3}{|c|}{ P valor } & & & & & & & & & & \\
\hline Dias & & $<0,0001$ & & & & & & & & & & \\
\hline Proteína* & & 0,2089 & & & & & & & & & & \\
\hline Mineral* & & 0,2106 & & & & & & & & & & \\
\hline Proteína* & heral*dias & 0,8236 & & & & & & & & & & \\
\hline
\end{tabular}

Fonte: Sarah Oliveira (2020).

${ }^{*} \mathrm{FCO}$ : farinha de carne e ossos; **FS: farelo de soja;

1'Inorg: tratamento controle com as fontes de zinco, manganês e cobre apenas sob a forma inorgânica; ${ }^{2} \mathrm{Zn}$ org: zinco complexado com aminioácidos; ${ }^{3 \mathrm{Mn}}$ org: manganês complexado com aminoácidos; ${ }^{4} \mathrm{Cu}$ org: cobre complexado com aminoácidos; ${ }^{5} \mathrm{Org}$ : fontes de zinco, manganês e cobre complexados com aminoácidos.

Ovos $A A=1, A=2$ e $B=3$, sendo que quanto menor o número, maior a qualidade do ovo.

Letras maiúsculas diferentes na mesma coluna indicam diferença entre os momentos $(P<0,05)$.

\subsubsection{Ovoscopia}

A avaliação de transluscência dos ovos foi feita com o uso de câmara escura, os resultados podem ser observados na Tabela 17. Houve efeito do tempo $(<0,0001)$, apontando para queda de qualidade da casca com o avançar da idade das aves. 
Tabela 17 - Valores médios para a ovoscopia, por meio de câmera escura com a incidência de feixe de luz, nos ovos produzidos por poedeiras Dekalb White, com idade inicial de 55 semanas que receberam $4 \%$ de farelo de carne e ossos (FCO) em substituição parcial ao farelo de soja e os elementos zinco, manganês e cobre isoladamente e associados na forma orgânica durante 42 semanas. São Paulo, 2020.

\begin{tabular}{|c|c|c|c|c|c|c|c|c|c|c|c|c|}
\hline \multirow{2}{*}{ Momento } & \multicolumn{2}{|c|}{ Fonte de proteína } & \multicolumn{5}{|c|}{ Fonte de Mineral } & \multirow{2}{*}{ Média } & \multirow{2}{*}{ EPM } & \multicolumn{3}{|c|}{ P valor } \\
\hline & $\mathrm{FCO}^{*}$ & $\mathrm{FS}^{* *}$ & $\operatorname{lnorg}^{1}$ & Zn org ${ }^{2}$ & Mn org ${ }^{3}$ & Cu org ${ }^{4}$ & $\mathrm{Org}^{5}$ & & & Proteína & Mineral & Proteína*mineral \\
\hline 1 & 1,8333 & 1,9467 & 2,0667 & 1,7833 & 1,8000 & 1,9833 & 1,8167 & $1,8900^{D}$ & 0,0378 & 0,1340 & 0,0600 & 0,5566 \\
\hline 2 & 1,9733 & 2,0133 & 2,2167 & 1,8333 & 1,9167 & 1,9667 & 2,0333 & $1,9933^{C D}$ & 0,0378 & 0,5967 & 0,0200 & 0,2234 \\
\hline 3 & 2,0600 & 1,9733 & 2,2000 & 2,0167 & 1,9500 & 1,8667 & 2,0500 & $2,0167^{c}$ & 0,0378 & 0,2517 & 0,0716 & 0,8947 \\
\hline 4 & 2,1733 & 2,2667 & 2,3833 & 2,1667 & 2,1667 & 2,1333 & 2,2500 & $2,2200^{8}$ & 0,0378 & 0,2171 & 0,2226 & 0,6007 \\
\hline 5 & 2,2533 & 2,2533 & 2,3833 & 2,3333 & 2,2833 & 2,0667 & 2,2000 & $2,2533^{A B}$ & 0,0378 & 1,0000 & 0,0707 & 0,3863 \\
\hline 6 & 2,0800 & 2,3000 & 2,3167 & 2,2333 & 2,1667 & 2,0833 & 2,1500 & $2,1900^{8}$ & 0,0378 & 0,0037 & 0,3547 & 0,0240 \\
\hline 7 & 2,2667 & 2,4333 & 2,4667 & 2,4833 & 2,2500 & 2,3167 & 2,2333 & $2,3500^{A}$ & 0,0378 & 0,0276 & 0,0977 & 0,7082 \\
\hline 8 & 1,9667 & 2,0867 & 2,1167 & 1,9000 & 2,1167 & 2,0000 & 2,0000 & $2,0267^{c}$ & 0,0378 & 0,1126 & 0,3184 & 0,5610 \\
\hline Média & 2,0758 & 2,1592 & 2,2687 & 2,0937 & 2,0812 & 2,0521 & 2,0917 & 2,1175 & 0,0142 & 0,7088 & 0,5068 & 0,3533 \\
\hline \multicolumn{13}{|c|}{ P valor } \\
\hline Dias & & $<0,0001$ & & & & & & & & & & \\
\hline Proteína* $\mathrm{C}$ & & 0,1254 & & & & & & & & & & \\
\hline Mineral*D & & 0,5106 & & & & & & & & & & \\
\hline Proteina*N & neral*dias & 0,7692 & & & & & & & & & & \\
\hline
\end{tabular}

Fonte: Sarah Oliveira (2020).

${ }^{*} \mathrm{FCO}$ : farinha de carne e ossos; ${ }^{* *} \mathrm{FS}$ : farelo de soja;

IInorg: tratamento controle com as fontes de zinco, manganês e cobre apenas sob a forma inorgânica; ${ }^{2} \mathrm{Zn}$ org: zinco complexado com aminioácidos; ${ }^{3} \mathrm{Mn}$ org: manganês complexado com aminoácidos; ${ }^{4} \mathrm{Cu}$ org: cobre complexado com aminoácidos; ${ }^{5} \mathrm{Org}$ : fontes de zinco, manganês e cobre complexados com aminoácidos.

Letras maiúsculas diferentes na mesma coluna indicam diferença entre os momentos $(P<0,05)$. Os momentos de 1 a 8 compreendem coleta de dados da $26^{\circ}$ até $42^{\circ}$, totalizando 16 semanas condensadas em 8.

4.4 Resultado: Saúde animal

Na sequência serão apresentados os resultados obtidos, durante as 42 semanas do período experimental, em relação à saúde animal.

\subsubsection{Peso das galinhas}

A Tabela 18 mostra os valores médios para o peso das poedeiras durante o estudo. Nela podemos observar apenas o efeito do tempo $(P<0,0001)$ sobre 0 peso das aves, que tendeu a aumentar com o avançar da idade. 
Tabela 18 - Valores médios para o peso das poedeiras $(\mathrm{kg})$ Dekalb White, com idade inicial de 55 semanas que receberam $4 \%$ de farelo de carne e ossos (FCO) em substituição parcial ao farelo de soja e os elementos zinco, manganês e cobre isoladamente e associados na forma orgânica durante 42 semanas. São Paulo, 2020

\begin{tabular}{|c|c|c|c|c|c|c|c|c|c|c|c|c|}
\hline \multirow{2}{*}{ Tempo } & \multicolumn{2}{|c|}{ Fonte de proteína } & \multicolumn{5}{|c|}{ Fonte de Mineral } & \multirow{2}{*}{ Média } & \multirow{2}{*}{ EPM } & \multicolumn{3}{|c|}{ P valor } \\
\hline & $\mathrm{FCO}^{*}$ & $\mathrm{FS}^{* *}$ & Inorg $^{1}$ & Zn org ${ }^{2}$ & Mn org ${ }^{3}$ & $\mathrm{Cu}_{\mathrm{org}}{ }^{4}$ & $\mathrm{Org}^{5}$ & & & Proteína & Mineral & Proteína*mineral \\
\hline 0 dias & 1,4943 & 1,4961 & 1,4906 & 1,4725 & 1,4947 & 1,5108 & 1,5075 & $1,4952^{\circ}$ & 0,0086 & 0,8476 & 0,1131 & 0,8529 \\
\hline 60 dias & 1,4691 & 1,4722 & 1,4685 & 1,4294 & 1,4753 & 1,4861 & 1,4940 & $1,4707^{F}$ & 0,0088 & 0,7929 & 0,0024 & 0,2516 \\
\hline 120 dias & 1,4790 & 1,4804 & 1,4810 & 1,4560 & 1,4795 & 1,4861 & 1,4960 & $1,4797^{\mathrm{E}}$ & 0,0087 & 0,8723 & 0,171 & 0,3938 \\
\hline 180 dias & 1,5097 & 1,5206 & 1,5044 & 1,5035 & 1,5071 & 1,5193 & 1,5415 & $1,5151^{\mathrm{C}}$ & 0,0091 & 0,3402 & 0,2201 & 0,1826 \\
\hline 240 dias & 1,5352 & 1,5375 & 1,5367 & 1,5240 & 1,5353 & 1,5428 & 1,5429 & $1,5363^{8}$ & 0,0092 & 0,8396 & 0,8780 & 0,6567 \\
\hline 300 dias & 1,5536 & 1,5604 & 1,5631 & 1,5373 & 1,5562 & 1,5612 & 1,5673 & $1,5570^{A}$ & 0,0092 & 0,5702 & 0,5909 & 0,7363 \\
\hline Média & 1,5068 & 1,5112 & 1,5074 & 1,4871 & 1,5080 & 1,5177 & 1,5249 & 1,5077 & 0,0024 & 0,6337 & 0,1315 & 0,5876 \\
\hline
\end{tabular}

P valor

\begin{tabular}{lc}
\hline Dias & $<0,0001$ \\
Proteína*Dias & 0,8906 \\
Mineral*Dias $^{*}$ & 0,3080 \\
Proteína*Mineral $^{*}$ dias & 0,1126 \\
\hline
\end{tabular}

Fonte: Sarah Oliveira (2020).

*FCO: farinha de carne e ossos; **FS: farelo de soja;

IInorg: tratamento controle com as fontes de zinco, manganês e cobre apenas sob a forma inorgânica; ${ }^{2} \mathrm{Zn}$ org: zinco complexado com aminioácidos; ${ }^{3} \mathrm{Mn}$ org: manganês complexado com aminoácidos; ${ }^{4} \mathrm{Cu}$ org: cobre complexado com aminoácidos; ${ }^{5} \mathrm{Org}$ : fontes de zinco, manganês e cobre complexados com aminoácidos.

Letras maiúsculas diferentes na mesma coluna indicam diferença entre os momentos $(P<0,05)$.

\subsubsection{Atividade da enzima superóxido dismutase}

A Tabela 19 mostra os valores médios para a atividade da enzima superóxido dismutase durante o estudo. Nela pode-se observar a influência do tempo $(\mathrm{P}<0,0001)$, que mostrou proporcionar aumento da atividade dessa enzima antioxidante com o avançar da idade das poedeiras. 
Tabela 19 - Valores médios para a atividade da enzima superóxido dismutase $(\mathrm{U} / \mathrm{ml})$ em poedeiras Dekalb White, com idade inicial de 55 semanas que receberam $4 \%$ de farelo de carne e ossos (FCO) em substituição parcial ao farelo de soja e os elementos zinco, manganês e cobre isoladamente e associados na forma orgânica durante 42 semanas. São Paulo, 2020

\begin{tabular}{|c|c|c|c|c|c|c|c|c|c|c|c|c|}
\hline \multirow{2}{*}{ Tempo } & \multicolumn{2}{|c|}{ Fonte de proteína } & \multicolumn{5}{|c|}{ Fonte de Mineral } & \multirow{2}{*}{ Média } & \multirow{2}{*}{ EPM } & \multicolumn{3}{|c|}{ P valor } \\
\hline & $\mathrm{FCO}^{*}$ & $\mathrm{FS}^{* *}$ & Inorg $^{1}$ & Zn org ${ }^{2}$ & Mn $\operatorname{org}^{3}$ & Cu org 4 & Org $^{5}$ & & & Proteína & Mineral & Proteína*mineral \\
\hline 0 dias & 0,8664 & 0,8640 & 0,8558 & 0,9029 & 0,8564 & 0,8624 & 0,8486 & $0,8652^{c}$ & 0,0167 & 0,8317 & 0,7721 & 0,6590 \\
\hline 60 dias & 0,7802 & 0,7816 & 0,7724 & 0,8135 & 0,7690 & 0,7728 & 0,7768 & $0,7809^{\circ}$ & 0,0150 & 0,9346 & 0,8511 & 0,6125 \\
\hline 120 dias & 0,9852 & 0,9815 & 0,9911 & 0,9841 & 0,9493 & 0,9609 & 1,0316 & $0,9834^{8}$ & 0,0201 & 0,8546 & 0,8142 & 0,9217 \\
\hline 180 dias & 0,9515 & 0,9877 & 0,9677 & 0,9867 & 0,9568 & 0,9006 & 1,0362 & $0,9696^{8}$ & 0,0161 & 0,2252 & 0,0461 & 0,1196 \\
\hline 240 dias & 1,0976 & 1,1709 & 1,2411 & 1,0946 & 1,1109 & 1,1241 & 1,1008 & $1,1343^{A}$ & 0,0210 & 0,0693 & 0,2399 & 0,2902 \\
\hline 300 dias & 0,9406 & 1,0000 & 0,9818 & 0,9993 & 0,9771 & 0,9300 & 0,9633 & $0,9703^{8}$ & 0,0132 & 0,0250 & 0,5174 & 0,4367 \\
\hline Média & 0,9369 & 0,9643 & 0,9683 & 0,9635 & 0,9366 & 0,9251 & 0,9595 & 0,9520 & 0,0088 & 0,0946 & 0,2458 & 0,7566 \\
\hline \multicolumn{3}{|c|}{ P valor } & & & & & & & & & & \\
\hline Dias & & $<0,0001$ & & & & & & & & & & \\
\hline Proteina & & 0,6132 & & & & & & & & & & \\
\hline Mineral* & & 0,6862 & & & & & & & & & & \\
\hline Proteína & neral*dias & 0,6898 & & & & & & & & & & \\
\hline
\end{tabular}

Fonte: Sarah Oliveira (2020).

${ }^{*} \mathrm{FCO}$ : farinha de carne e ossos; ${ }^{*} \mathrm{FS}$ : farelo de soja;

1'Inorg: tratamento controle com as fontes de zinco, manganês e cobre apenas sob a forma inorgânica; ${ }^{2} \mathrm{Zn}$ org: zinco complexado com aminioácidos; ${ }^{3} \mathrm{Mn}$ org: manganês complexado com aminoácidos; ${ }^{4} \mathrm{Cu}$ org: cobre complexado com aminoácidos; ${ }^{5} \mathrm{Org}$ : fontes de zinco, manganês e cobre complexados com aminoácidos.

Letras maiúsculas diferentes na mesma coluna indicam diferença entre os momentos $(P<0,05)$.

\subsubsection{Densitometria óssea}

O gráfico 7 mostra os resultados obtidos na análise de densitometria óssea da tíbia direita das aves. Não foi observada diferença entre os grupos estudados para essa variável. 
Gráfico 7 - Valores médios para a densitometria óssea realizada nas tíbias direitas de poedeiras Dekalb White, que receberam $4 \%$ de farinha de carne e ossos (FCO) em substituição parcial ao farelo de soja e os elementos zinco, manganês e cobre, isoladamente e/ou associados na forma orgânica durante 40 semanas. São Paulo, 2020.

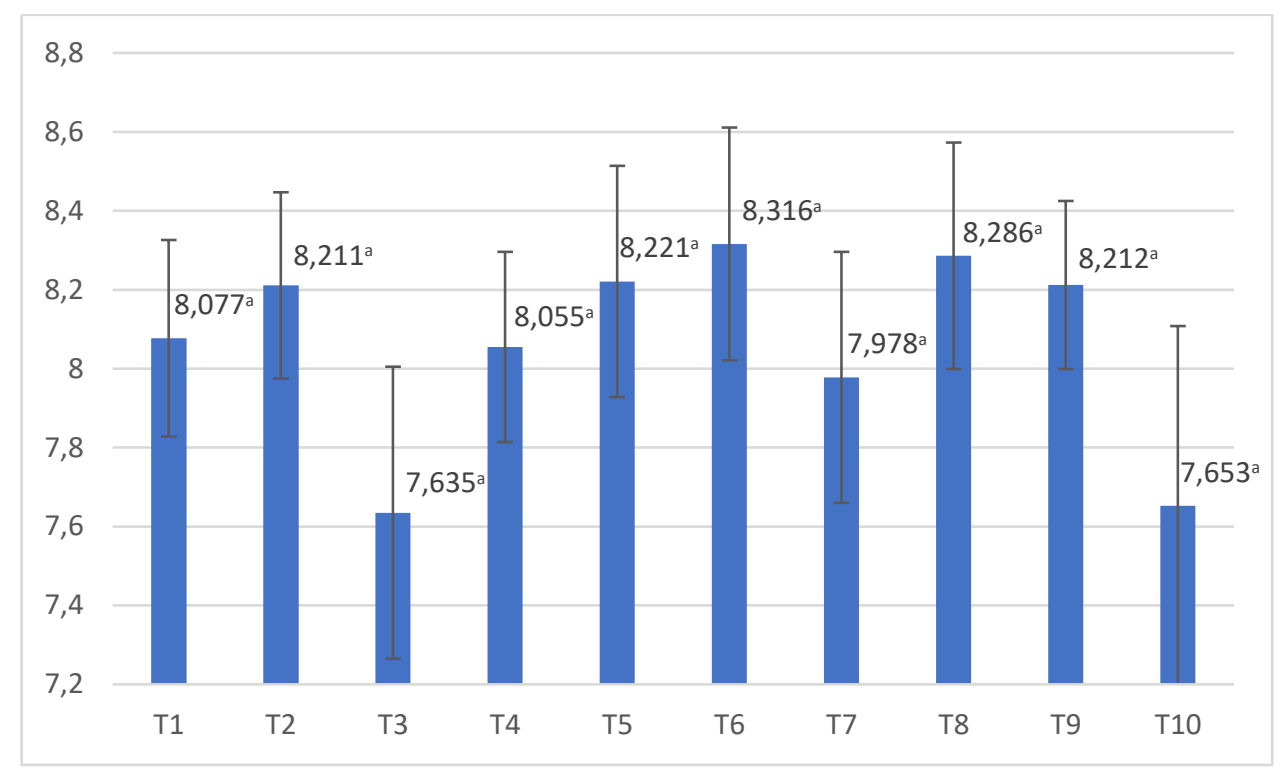

Fonte: Sarah Oliveira (2020).

*T1: minerais cobre, zinco e manganês inorgânicos com 4\% de farinha de carne e ossos (FCO) em substituição parcial ao farelo de soja; T2: zinco orgânico complexado com aminoácidos com $4 \%$ de farinha de carne e ossos (FCO) em substituição parcial ao farelo de soja; T3: manganês orgânico complexado com aminoácidos com $4 \%$ de farinha de carne e ossos (FCO) em substituição parcial ao farelo de soja; T4: cobre orgânico complexado com aminoácidos com 4\% de farinha de carne e ossos (FCO) em substituição parcial ao farelo de soja; T5: minerais cobre, zinco e manganês orgânicos complexado com aminoácidos com $4 \%$ de farinha de carne e ossos (FCO) em substituição parcial ao farelo de soja; T6; minerais cobre, zinco e manganês inorgânicos com farelo de soja como única fonte de proteína; T7: zinco orgânico complexado com aminoácidos com farelo de soja como única fonte de proteína ; T8: manganês orgânico complexado com aminoácidos com farelo de soja como única fonte de proteína ; T9: cobre orgânico complexado com aminoácidos com farelo de soja como única fonte de proteína; T10: minerais cobre, zinco e manganês orgânicos complexado com farelo de soja como única fonte de proteína.

${ }^{* *}$ As médias representam dez aves por cada tratamentos.

\section{DISCUSSÃO}

Todos os resultados encontrados no presente estudo tiveram influência do tempo. Com o avanço da idade da ave, normalmente ocorre declínio na produção, aumento no peso dos ovos, alterações na composição e espessura da casca (MÁCHAL e SIMEONOVOVÁ, 2002), embora se observe aumento significativo no tamanho dos ovos. Este fato parece estar relacionado ao aumento da incidência da atresia folicular e redução no recrutamento dos folículos dentro da hierarquia. Folículos pré-ovulatórios de poedeiras velhas 
maturam mais lentamente e ovulam quando atingem tamanho maior quando comparado com aves jovens (RUTZ et al., 2007b). RAMOS et al. (2010) demonstraram que a percentagem de casca é afetada pela idade da poedeira, aves mais jovens apresentaram maior percentagem de casca em relação as mais velhas. De acordo com Keshavarz e Nakajima, (1993) o decréscimo da qualidade da casca, com o avançar da idade, é resultado da queda de habilidade na absorção de cálcio intestinal e menor mobilização do cálcio ósseo. A taxa de retenção deste íon em aves jovens é de $60 \%$, enquanto nas mais velhas é de $40 \%$. É normalmente aceito, que a qualidade da casca medida pela espessura e gravidade específica seja negativamente afetada pela idade da ave. O peso da casca permanece relativamente constante, enquanto o peso do ovo aumenta com a idade, esta relação acontece certamente devido a reduções da espessura da casca durante o ciclo de postura (CARVALHO et al., 2007; ROBERTS, 2010).

MENEZES et al. (2012) estudaram a influência da idade de poedeiras na qualidade de ovos, utilizando poedeiras com 35, 40, 45 e 50 semanas. Galinhas jovens, com até 35 semanas de idade, apresentaram valores mais elevados em altura de albúmen (5,836 mm), em comparação a galinhas de 40 (5,455 mm), 45 $(5,153 \mathrm{~mm})$ e 50 (4,487 mm) semanas de idade, assim como em Unidade Haugh (UH). Os autores concluíram que a idade influencia diretamente na qualidade física dos ovos. SILVERSIDES \& SCOTT (2001) e CARVALHO et al. (2007) observaram que o ovo aumenta de tamanho com o avanço da idade e apresentam maior percentagem de gema, porém, a percentagem de albúmen, altura de albúmen, gravidade específica e UH diminuem, evidenciando que a qualidade interna do ovo tende a piorar com o avanço da idade. RAMOS et al. (2010), analisando a idade das poedeiras, verificaram que houve diferença significativa com relação ao peso dos ovos quando comparadas as três diferentes idades (24, 55 e 107 semanas), assim como verificaram diferenças com relação à altura do albúmen e a $\mathrm{UH}$, confirmando o já observado por CARVALHO et al. (2007). Todos estes resultados convergem aos encontrados no presente estudo, onde observamos maior peso do ovo, menor altura de albúmen e menores valores para UH para galinhas de idade mais avançada (97 semanas de idade ao final do estudo). 
Além do efeito da idade das aves, observamos queda no peso dos ovos no tratamento contendo zinco orgânico e apenas farelo de soja como fonte proteica (T7) aos 60 dias. Essa queda pode ser explicada pelo menor consumo de ração deste tratamento no mesmo período. Um dos possíveis motivos para tal redução poderia ser explicado pela alta temperatura no interior do galpão no período, que chegou a atingir mais de $31^{\circ} \mathrm{C}$, sendo que a temperatura ambiental ideal para aves fica entre 21 e $23^{\circ} \mathrm{C}$. Fisiologicamente as aves respondem ao estresse térmico por calor aumentando os mecanismos de dissipação e diminuindo a produção de calor metabólico, ou termogênese, reduzindo a ingestão de alimentos, assim como o consumo de energia metabolizável (MUJAHID et al., 2007), consequentemente essas aves tem redução no ganho de peso e conversão alimentar. A redução do consumo de ração diminui o consumo de outros nutrientes de suma importância para a produção de ovos, como aminoácidos e minerais (STRINGHINI et al., 2005). Porém como todos os tratamentos estavam inseridos no mesmo galpão, e apenas o T7 obteve maior queda no peso do ovo, consumo de ração e consequentemente pior conversão alimentar, não podemos atribuir o motivo à temperatura em sua totalidade.

A análise bromatológica da ração T7 revelou que esse tratamento também apresentava alto teor de proteína bruta no período, tais teores podem ter aumentado a carga de calor a ser dissipado, o que possivelmente comprometeu, nesse caso, o desempenho das aves (COSTA et al., 2015). Pelo fato de os aminoácidos participarem de grande variedade de reações metabólicas no organismo animal, pensava-se que qualquer excesso ou deficiência deles, não provocaria efeitos negativos. No entanto, tem-se observado que a ingestão desproporcional de aminoácidos (essenciais ou não essenciais) em quantidades ou padrões diferentes daqueles requeridos para máxima utilização pelos tecidos, resultam em efeitos adversos ao animal (SCHMIDT et al., 2010) e interferem diretamente na resposta produtiva das poedeiras (CUPERTINO et al., 2009). Assim, teores excessivos/elevados de proteína na ração não significam apenas alto custo de formulação, mas também potenciais problemas no desempenho produtivo. Em condições de temperatura elevada, o ideal para se manter 0 balanço energético das aves, seria a redução do teor proteico da dieta, o que implicaria em redução no catabolismo da proteína, resultando em decréscimo na 
produção de calor (DAGHIR, 1995). Desta forma, deve-se aumentar a quantidade de aminoácidos sintéticos com o mínimo incremento de proteína para não ocorrer aumento na produção de calor endógeno gerado pela digestão proteica (GARCIA, 2004).

Fora os fatores temperatura e proteína bruta, o resultado encontrado vai ao encontro do obtido no estudo de TRINDADE NETO et. al (2011), que verificaram que o aumento nos teores suplementares de zinco (137 para 655 $\mathrm{mg} / \mathrm{kg}$ de ração) usando na avaliação uma fonte orgânica, foi prejudicial ao desempenho e qualidade de ovos de poedeiras semipesadas tanto na fase inicial, quanto na fase final do ciclo de produção. Segundo os autores este fato pode estar associado ao efeito deletério deste microelemento sobre o consumo de ração, assim como a competição por sítios de absorção (interações) com outros elementos, igualmente importante no metabolismo de poedeiras em produção. Em contrapartida, aos resultados para consumo de ração encontrados por FERNANDES et al. (2008), com o uso de mix contendo Zn, Mn e selênio nas concentrações de 0,250 ppm e 0,500 ppm, e MACIEL et al. (2010), com o uso de dieta suplementada em 50\% de Zn, Mn e Cu na forma orgânica e 50\% na forma inorgânica, não demonstram alteração no consumo de ração de poedeiras.

A conversão alimentar por dúzia, além de ter piorado com o tempo devido à queda na produção de ovos, também revelou que os tratamentos inorgânicos (T1 a T6) tiveram resultado superior quando comparados aos orgânicos. Estes resultados vão contra aqueles obtidos por CARVALHO (2012), com o uso dos minerais orgânicos $\mathrm{Cu}, \mathrm{Zn}, \mathrm{Mn}$ e ferro em teores de inclusão de 100\%, 90\%, 80\% e $70 \%$, o qual observou que poedeiras alimentadas com $100 \%$ dos minerais na forma orgânica apresentaram maior potencial de produção de ovos e melhora na conversão alimentar por dúzia em relação às que receberam 100\% na forma inorgânica. Resultados distintos foram encontrados por SUN et al. (2012) que em pesquisa com poedeiras de primeiro ciclo de postura não observaram qualquer efeito da suplementação de microelementos de fonte orgânica sobre o percentual de produção e conversão alimentar por dúzia. Porém, concluíram que os microelementos de fontes orgânicas apresentaram maior disponibilidade biológica por ter havido incremento na espessura da casca dos ovos, maior 
retenção mineral e atividade enzimática em poedeiras comerciais. GHEISARI et al. (2011) não encontraram diferenças no percentual de produção de ovos, no entanto, a conversão alimentar por massa foi melhorada quando as aves foram alimentadas com dietas contendo microelementos na forma orgânica. Os autores avaliaram os efeitos do fornecimento de dietas contendo microelementos cobre, manganês e zinco em sua forma orgânica para aves no primeiro ciclo de postura. Os resultados demonstraram que as aves mantiveram a produção e houve melhora na qualidade dos ovos mesmo quando os teores de inclusão foram de 50 a 75\% menores que o recomendado pelo NRC (1994). Também testando tais microelementos, BORUTA et al. (2007) avaliaram o peso dos ovos, percentual de produção e conversão alimentar e não observaram diferença mesmo quando os minerais foram incluídos na forma orgânica a uma quantidade 12 vezes menor que o teor dos elementos inorgânicos utilizados comercialmente, o que mostra uma biodisponibilidade alta das fontes orgânicas.

A espessura e porcentagem da casca no presente estudo não foi influenciada pela forma da suplementação mineral, dado que concorda com os encontrados por SALDANHA et al. (2009), que substituíram proporcionalmente a dieta controle de microelementos inorgânicos em cinco teores $(110,100,90$, $80,70 \%$ ) com um suplemento mineral orgânico contendo 30;30;40;6; 0,61 e $0,3 \mathrm{~g} / \mathrm{kg}$ de produto de $\mathrm{Zn}$, Ferro, Mn, Cu, lodo, e Selênio, respectivamente, em poedeiras de segundo ciclo. Neste estudo os parâmetros avaliados de espessura e porcentagem de casca, gravidade específica, índice de gema, unidades Haugh e resistência da casca não foram influenciados pelos teores e fontes dos minerais. Os mesmos resultados foram obtidos por MABE et al. (2003) que, em estudo com poedeiras de idade de 32, 60 e 69 semanas, suplementaram as dietas com 32,6 mg/kg de Zn, 24,7 mg/kg de $\mathrm{Mn}$ e 4,95 mg/kg de $\mathrm{Cu}$, não observando influência alguma nos dados de porcentagem de casca, índice de casca (peso da casca por unidade de área de superfície) e rigidez da casca. SWIATKIEWICZ E KORELESKI (2008) também não observaram qualquer influência dos minerais zinco e manganês de fonte orgânica sobre o percentual e espessura de casca, mas concluíram que a utilização desses minerais, quando substituídos em sua totalidade, foi benéfica em atenuar o efeito da idade das aves sobre a resistência a quebra da casca dos ovos (medida por meio do Instron 
5542 na velocidade de $10 \mathrm{~mm} / \mathrm{min}$ ). Em contrapartida, Carvalho (2012) observou que aves já no segundo ciclo de postura, alimentadas com elementos orgânicos (inclusão dos minerais cobre, ferro, manganês e zinco orgânicos em 100\%, 90\%, $80 \%$ e $70 \%$ de substituição aos elementos inorgânicos) obtiveram espessura de casca maior em relação àquelas alimentadas com elementos inorgânicos. Siske et al. (2000) observaram aumento na espessura da casca de ovos de poedeiras quando $50 \%$ dos minerais inorgânicos foram substituídos por fonte orgânica. Bunesova (1999) e Klecker et al. (2002) encontraram efeito positivo da substituição parcial de fontes inorgânicas de Zn e Mn com suas formas orgânicas no peso e espessura da casca do ovo.

Os resultados da ovoscopia neste estudo não foram influenciados pelos minerais orgânicos $\mathrm{Cu}, \mathrm{Zn}$ e $\mathrm{Mn}$, dado que concorda com os encontrados por Carvalho (2012). Resultados diferentes foram observados por Rossi (2018), que notou melhora na porosidade da casca utilizando concentrações de 30, 30, 40, 6, 0,61 e 0,3 g/kg de Zn, Ferro, Mn, Cu, lodo e Selênio, respectivamente.

Os valores obtidos de densidade óssea realizada na tíbia direita de Dekalb White não apresentaram interação entre os fatores estudados. Santos (2008) obteve resultado semelhante em estudo com diferentes programas nutricionais $(95 \%$ das exigências nutricionais, 100\% das exigências nutricionais e 105\% das exigências nutricionais preconizadas pelo Manual Hy-Line).

De modo geral, o estudo revelou que os minerais utilizados, na quantidade utilizada e pelo período do estudo, não interferiram na qualidade interna e externa do ovo. Resultados parecidos foram obtidos por Fernandes et al. (2008), que não verificaram melhora no desempenho e qualidade externa dos ovos de poedeiras leves em final de ciclo de produção, alimentadas com fontes orgânicas de zinco, manganês e selênio em detrimento ao grupo de aves suplementadas com esses elementos provenientes de fontes convencionais ou inorgânicas. Passos (2010), não observou qualquer benefício da suplementação extra ou da substituição de fontes convencionais por microelementos (zinco, cobre, manganês e selênio) na forma complexada ou orgânica sobre o desempenho e qualidade de ovos de poedeiras semipesadas em região de clima quente. Resultados semelhantes foram encontrados por Sechinato et al. (2006), que 
avaliaram as características de desempenho de poedeiras em primeiro ciclo de postura, concluindo que não houve benefício da suplementação de microelementos (zinco, manganês, iodo, selênio, cobre e ferro) oriundos de fontes orgânicas em detrimento às fontes convencionais ou inorgânicas em rações de poedeiras leves e afirmam ainda, que o conceito de maior biodisponibilidade relativa por parte de fontes orgânicas permanece controverso. Estes resultados vão ao encontro dos encontrados por Geraldo et al. (2012) e Fernandes et al. (2008) que também não encontraram efeitos benéficos da suplementação de fontes "orgânicas" sobre o desempenho de poedeiras comerciais. Em contrapartida a todos esses estudos, Maciel et al. (2010) observaram maior peso dos ovos, gravidade específica e menor percentual de perda de ovos quando as poedeiras de 80 semanas de idade foram suplementadas com $50 \%$ dos minerais zinco, manganês e cobre na forma orgânica.

Frente a tamanha divergência dos dados encontrados na literatura, devese levar em consideração fatores como idade das aves, composição da dieta, concentração de micro elementos da dieta basal, fonte e substituição relativa dos minerais, associados à diversidade de moléculas orgânicas disponíveis no mercado e diferentes procedimentos empregados durante o processo de quelação que resultam em produtos com biodisponibilidade, estabilidade e metabolização distintas (GHEISARI et al., 2011; FERNANDES et al., 2008).

Em relação a substituição de farelo de soja por farinha de carne e ossos (FCO), foi observado efeito negativo na qualidade do ovo, com diminuição no peso do ovo, altura do albúmen, unidade Haugh e gravidade específica, além do aumento no consumo de ração por parte das aves que consumiram $4 \%$ de FCO na sua dieta. De acordo com Brito (2009), o uso da farinha de carne e ossos pode prejudicar a qualidade sensorial dos ovos, além de trazer problemas nutricionais às aves. Porém, esses resultados são contrários aos encontrados por Silva et al. (2000), que compararam o desempenho de poedeiras alimentadas com dieta à base de milho e farelo de soja com uma dieta, de baixa digestibilidade, à base de subprodutos. A ração com farinha de carne e ossos reduziu o consumo em $7,8 \%$, o peso dos ovos em $2,5 \%$ e a massa de ovos em $2,2 \%$, mas a conversão alimentar foi $6 \%$ melhor. Neste mesmo estudo não houve 
efeito $(P>0,05)$ das rações sobre a qualidade interna dos ovos estimada pela unidade Haugh e pelos índices de gema e albúmen. Reduções de $2 \%$ no peso dos ovos também foram reportadas por Bougon e Joly (1990), mesmo quando a ração de baixa digestibilidade foi suplementada com lisina e metionina, esta diminuição de peso pode ser observada no presente estudo também, com ovos de galinhas alimentadas com farelo de soja mais pesados se comparado aos dos grupos de farinha de carne e ossos. Vale ressaltar que os coeficientes de digestibilidade dos aminoácidos em farinhas de carne e ossos, penas (BAKER et al., 1981; WANG e PARSONS, 1997) e vísceras (NASCIMENTO et al., 1999) são influenciados pelo sistema de processamento, pela temperatura, pelo tempo de cozimento, secagem e pela proporção dos componentes no produto, o que torna difícil comparar os vários estudos.

Também foi possível observar no estudo diferença na coloração da gema entre os grupos alimentados com farelo de soja e o com $4 \%$ de farinha de carne e ossos, na qual este último apresentou gema de cor mais intensa. $\mathrm{Na}$ composição das rações podemos notar aproximadamente 5 quilos a mais de milho da fórmula do grupo com farinha de carne e ossos. O milho é a principal fonte de pigmento amarelo em rações comerciais de aves. Esses pigmentantes naturais, como os carotenoides (xantofilas), caracterizam-se por compostos responsáveis pelas cores, amarelo, laranja e vermelho dos alimentos, frutas, alguns peixes, como salmão e a truta, alguns crustáceos e gema de ovo. Nas aves o metabolismo dos pigmentos como os carotenos presentes nos alimentos se dá pela absorção a luz do lúmen intestinal, onde os carotenoides são transportados juntamente com os lipídeos e adentram nas células pelas lipoproteínas presentes na membrana celular, estes pigmentos podem se acumular na célula de diversos tecidos ricos em lipídeos, como é o caso da gema do ovo (FAEHNRICH et al., 2016). 


\section{CONCLUSÃO}

No presente estudo:

a. A substituição parcial ou associada dos microelementos manganês, zinco e cobre de fontes inorgânicas por fontes orgânicas, não influenciou a qualidade do ovo e a saúde das aves, nem mesmo minimizou o efeito da idade sobre os parâmetros analisados.

b. A utilização de $4 \%$ de farinha de carne e ossos influenciou negativamente a qualidade interna do ovo das poedeiras nesse período de utilização.

c. Não houve benefício da utilização de 40 ppm de manganês, 40 ppm de zinco e de 7 ppm de cobre complexados a aminoácidos, em poedeiras Dekalb White no período de 55 a 97 semanas de idade. 


\section{REFERÊNCIAS}

AGUIAR, E.F.; SILVA DE OLIVEIRA, T; MEIRA, C.T.; de OLIVEIRA CASTRO, J.; dos SANTOS, G.C.; PINTO, G.V.D; MOREIRA, J. Diferentes microminerais suplementados em dietas para poedeiras comerciais e o efeito sobre os parêmetros de desempenho. In: Encontro latino-americano de iniciação científica, 13.; Encontro latino-americano de pós-graduação, 9.; Encontro latinoamericano de iniciação científica júnior ,3.; 2009, Diamantina Anais... Diamantina, 2009.

ALVES, E.L. Efeito dos níveis de cálcio em duas fontes sobre o desempenho de frangos de corte. Ciência agrotecnológica, Lavras, v.26, n.6, p.1305-1312, nov./dez., 2002.

ARAÚJO, M. S.; BARRETO, S.L.T.; GOMES, P.C.; DONZELE, J.L.; OLIVEIRA, W.P.; VALERIANO, M.H. Composição química e valor energético de alimentos de origem animal utilizados na alimentação de codornas japonesas. Revista Brasileira de Zootecnia 2011;40(2):331-335. 2011.

ARAÚJO, C.S.S.; ARAUJO, L.; ARTONI, S.M.B.; JUNQUEIRA, O.M.; LOUSADA, M.J. Bone Development of broiler chickens fed diets with different amino acid and calcium levels during the starter phase. International Journal Morphology. Chile. v.21(2). p.10, 2003.

ARAUJO, J. A., DA SILVA, J. H. V., DE LIMA AMÂNCIO, A. L., LIMA, C. B., \& DE OLIVEIRA, E. R. A. Fontes de minerais para poedeiras. Acta veterinária brasílica. v.2(3). p.53-60, 2008.

ASSOCIATION OF AMERICAN FEED CONTROL OFFICIAL (AAFCO). Official Publication. Atlanta, 2009.

ASSOCIATION OF OFFICIAL ANALYTICAL CHEMISTIS - AOAC. Official Methods of Analysis. $17 \mathrm{ed}$. Washington, DC.: Association of Oficial Analytical Chemistis. v.2. p.61-62, 2000.

BAIÃO, N.C.; CANÇADO, S.V. Fatores que afetam a qualidade da casca do ovo. Belo Horizonte, Escola de Veterinária, p. 43- 59, (Caderno técnico, 21).1997. 
BAKER, D.H., BLITENTHAL, R.C., BOEBEL, K.P. et al. 1981. Protein-amino acid evaluation of steam-processed feather meal. Poult. Sci., 60:1865-1872.

BALNAVE, D., \& ZHANG, D. Research note: responses of laying hens on saline drinking water to dietary supplementation with various zinc compounds. Poultry Science. v.72(3). p.603-606, 1993.

BAUMGARTNER, S., BROWN, D. J., SALEVSKY JR, E., \& LEACH JR, R. M. Copper deficiency in the laying hen. The Journal of nutrition. v.108(5). p.804$811,1978$.

BELLAVER, C. Limitações e vantagens do uso de farinhas de origem animal na alimentação de suínos e de aves. In: $2^{\circ}$ Simpósio Brasileiro Alltech da Indústria de Alimentação Animal. Versão atualizada. Curitiba, 2005.

BERTECHINI A.G. Nutrição de monogástricos. 1. ed. Lavras - MG: Ed. ufla. v.1. p.302, 2006.

BORUTA, A. et al. Trace organic minerals as a replacement of inorganic sources for layers: effects on productivity and mineral excretion. In: World Poultry Science Association, Proceedings of the 16th European Symposium on Poultry Nutrition, Strasbourg, France. p. 491-494. 2007.

BOUGON, M.; JOLY, P. Intérêt de formuler les aliments destinés aux pondeuses en acides aminés digestibles. In: Proceedings of the VIII Europen Poultry Conference. p. 306-314. 1990.

BOZKURT, M.; ALÇIÇEK, A.; ÇABUK, M. The effect of dietary inclusion of meat and bone meal on the performance of laying hens at old age. South African Journal of Animal Sciences, 2004.

BRITO, A.B. Avaliação de ingredientes para a nutrição de poedeiras comerciais. 2009.

BRITO, J.A.G; BERTECHINI, A.G; FASSANI, E.J; RODRIGUES, P.B; FREITAS, R.T.F. Uso de micromineirais sob a forma de complexo orgânico em rações para frangas de reposição no período de 7 a 12 semanas de idade. Revista Brasileira de Zootecnia, v.35, n.4, p.1342-1348, 2006.

BUNESOVA, A. Chelated trace minerals (Zn, Mn) in nutrition of hens. Zeszyty 
Naukowe. Przegląd Hodowlany, v. 45, 1999.

CARVALHO, F.B.; STRINGHINI, J.H.; JARDIM FILHO, R.M. et al. Qualidade interna e da casca para ovos de poedeiras comerciais de diferentes linhagens e idades. Revista Ciência Animal Brasileira, v.8, p. 25-29, 2007

CARVALHO, Letícia Souza Silva. Desempenho produtivo e qualidade de ovos de galinhas poedeiras em segundo ciclo de postura alimentadas com minerais orgânicos. 2012. 70 f. Dissertação (Mestrado em Ciências Agrárias) Universidade Federal de Uberlândia, Uberlândia, 2012.

CASTELLÓ, J.A.L.; PONTES, M.; GONZÁLEZ, F.F. Producción de huevos. 1aㅗ ed. Barcelona: Real Escuela de Avicultura. p.367, 1989.

ÇATLI, A. U. et al. Performance and egg quality of aged laying hens fed diets supplemented with meat and bone meal or oyster shell meal. South African Journal of Animal Sciences, 2012.

COSTA, F. G. P., PINHEIRO, S. G., \& LIMA, M. Exigências de aminoácidos para poedeiras. In 29a Reunião do CBNA-Congresso sobre Nutrição de Aves e Suínos. v.29, 2015.

COTTA, T. Produção de pintinhos: manual prático. Viçosa, MG: Aprenda Fácil. p.191, 2002.

COUSINS, R. J. Absorption, transport, and hepatic metabolism of copper and zinc: special reference to metallothionein and ceruloplasmin. Physiological reviews. v.65(2). p.238-309, 1985.

COUTTS, J.A.; WILSON, G.C.; FERNANDEZ, S. Optimum egg quality - A practical approach. Sheffield: 5M Enterprises. 66p. 2007.

CUPERTINO, E. S. Exigências nutricionais de lisina, de metionina + cistina e de treonina para galinhas poedeiras no período de 54 a 70 semanas de idade. Tese (Doutorado em Zootecnia) - Universidade Ferderal de Viçosa. Viçosa. 134p. 2006.

DAGHIR, N. J. Poutry production in hot climates. Cambridge University Press.p.303.1995. 
DAWSON, C. O., SAVAGE, G. P. Biological Value of Some New Zealand Processed Meals. The Prooceedings of the Nutrition Society, v. 8, p. 138-139, 1983.

FAEHNRICH, B., LUKAS, B., HUMER, E., ZEBELI, Q. Phytogenic pigments in animal nutrition: potentials and risks. Revisão, J Sci Food Agric. 96: 1420-1430. 2016.

FARIA FILHO, D. E.; JUNQUEIRA, O. M.; RIZZO, M. F.; ARAÚJO, L.F. Avaliação da farinha de carne e ossos na alimentação de frangos de corte. Revista Brasileira de Ciência Avícola. 4(1):1-9. 2002.

FASSANI, E.J.; BERTECHINI, G.A.; OLIVEIRA, B.L.; GONÇALVES, T.M.; FIALHO, E.T. Manganês na nutrição de poedeiras no segundo ciclo de produção. Ciência Agrotécnica, Lavras. v.24(2). p.468-478, 2000.

FERNANDES, J.I.M. et al. Effect of organic mineral dietary supplementation production performance and egg quality of white layers. Brazilian Journal of Poultry Science, v.10, n.1, p.59-65, 2008.

FISKE, Cyrus $\mathrm{H}$. et al. The colorimetric determination of phosphorus. J. biol. Chem, v. 66, n. 2, p. 375-400, 1925.

FISHER, C. Use of copper sulfate as a growth-promoter for broilers. Feedstuffs, July 16. p.24-5, 1973.

GARCIA, J. R. M. Avanços na nutrição da poedeira moderna. 2004.

GENEROSO, R. A. R.; GOMES, P. C.; ROSTAGNO, H. S.; ALBINO, L. F. T.; BARRETO, S. L. T.; BRUMANO, G. Composição química e energética de alguns alimentos para frangos de corte em duas idades. Revista Brasileira de Zootecnia. 37(7):1251-1256. 2008.

GERAldo, A., PINTO, D. M., BRITO, J. A., BERNARDES, M. H., SILVA JUNIOR, A. L., \& MACHADO, L. C. Diferentes programas de suplementação de microminerais para poedeiras semipesadas em primeiro ciclo de produção. Arquivos de Pesquisa Animal, 1(1), 48-57. 2012.

GHEISARI, A. A.; ET AL. Effect of diets supplemented with different levels of manganese, zinc, and copper from their organic or inorganic sources on egg 
production and quality characteristics in laying hens. Biological Trace Element Research, v. 142, n. 3, p. 557-571, 2011.

GREGORY N.G., WILKINS L.J. Broken bones in domestic fowl: handling and processing damage in end-of-lay battery hens. British Poultry Science. v.30. p.555-562, 1989.

GRIMINGER, P. Effect of copper sulfate on egg production and shell thickness. Poultry Science. v.56. p.359-61, 1977.

GUO, R.; HENRY, P.R.; HOLWERDA, R.A. et al. Chemical characteristics and relative bioavailability of supplemental organic copper sources for poultry. Journal of Animal Science, v.79, p.1132-1141, 2001.

HOLDER, D.P., HUNTLEY, D.M. Influence of added manganese, magnesium, zinc, and calcium level on egg shell quality. Poult. Sci. v.57(6). p.1629-34, 1978.

Hudson, B. P., Dozier lii, W. A., Wilson, J. L., Sander, J. E., \& Ward, T. L. Reproductive performance and immune status of caged broiler breeder hens provided diets supplemented with either inorganic or organic sources of zinc from hatching to 65 wk of age. Journal of Applied Poultry Research, 13(2), 349-359. 2004.

HUNTON, P. Research on eggshell structure and quality: An historical overview. Revista Brasileira de Ciência Avícola, Campinas, v. 7, n. 2, p. 67-71, Apr./Jun. 2005.

KESHAVARZ, K. Laying hens respond differently to high dietary levels of phosphorus in monobasic and dibasic phosfate. Poultry Science, Champaing, v.73(5). p.687-703, 1994.

KESHAVARZ, K.; NAKAJIMA, S. Reevaluation of calcium and phosphorus requirements of laying hens for optimum performance and eggshell quality. Poultry Science, Champaign, v. 72, n. 1, p. 144-153, Jan. 1993.

KIENHOLZ, E. W. Zinc methionine for stressed laying hens. Poultry Science. v. 71. p.829-832,1992.

KLECKER, D. et al. Effect of manganese and zinc chelates on the quality of eggs. Acta Universitatis Agriculturae et Sylviculturae Mendelianae Brunensis (Czech 
Republic), 2002.

LEACH, JR. \& GROSS, J.R. The effect of manganese deficiency upon the ultra structure of the eggshell. Poultry Science. v.62. p.499-504, 1983.

LEESON, S.; SUMMERS, J. D. Nutrition of the Chicken. Guelph: University Books. 482p. 2001.

LEESON, S; SUMMERS, J. D. Commercial Poultry Nutrition. 3 rd ed, Guelph: University Books. 398 p. 2005.

LOUZADA, M. J. Q. Densidade de peças ósseas de frangos. Estudo pela densitometria óptica radiográfica. Veterinária e Zootecnia. v. 9, p. 95-109, 1997.

LOUZADA, M. J. Q.; PELÁ, C.;BELANGERO,W.D.; SANTOS-PINTO, R.; Avaliações de densidade óssea em imagens radiográficas: estudo em peças ósseas de cães. RBE - Caderno de Engenharia Biomédica, v. 14, n. 1, p. 47$64,1998 \mathrm{a}$

LOUZADA, M. J. Q.; PELÁ, C.;BELANGERO,W.D.; SANTOS-PINTO, R.; Metodologia para a avaliação de densidade em imagem radiográfica. RBE Caderno de Engenharia Biomédica, v. 14, n. 2, p. 37- 47, 1998 b.

MABE, I. Efeitos da suplementação dietética com quelatos de zinco e de manganês na produção, qualidade de ovos e morfologia intestinal de galinhas poedeiras. Tese Doutorado. FCF - Faculdade de Ciências Farmacêuticas, São Paulo. 2001.

MABE, I. et al. Supplementation of a corn-soybean meal diet with manganese, copper, and zinc from organic or inorganic sources improves eggshell quality in aged laying hens. Poultry Science, v. 82, n. 12, p. 1903-1913, 2003.

MÁCHAL, L.; SIMEONOVOVÁ, J. The relationship of shortening and strength of eggshell to some egg quality indicators and egg production in hens of different initial laying lines. Archiv für Tierzucht, Dummerstorf, v. 45, n. 3, p. 287-296, 2002.

MACIEL, M.P. et al. Effect of using organic microminerals on performance and external quality of eggs of commercial laying hens at the end of laying. Revista Brasileira de Zootecnia, v.39, n.2, p.344-348, 2010. 
MAGALHÃES, Ana Paula Carvalho et al. Qualidade de ovos comerciais de acordo com a integridade da casca, tipo de embalagem e tempo de armazenamento. 2007.

MAIORKA, A.; MACARI, M. Equilíbrio ácido-básico. In: MACARI, M.; FURLAN, R.L.; GONZALES, E. (Ed.) Fisiologia aviária aplicada a frangos de corte. 2.ed. Jaboticabal: FUNEP. p.167-173. 2002.

MAZZUCO, Helenice. Osteoporose em poedeiras comerciais: uma doença metabólica multifatorial. Embrapa Suínos e Aves-Circular Técnica (INFOTECA-E), 2005.

MCDOWELL L.R. Minerals in animal and human nutrition. San Diego: Academic Press. p.524, 1992.

MENEZES, P.C.; LIMA, E.R.; MEDEIROS, J.P. et al. Egg quality of laying hens in different conditions of storage, ages and housing densities. Revista Brasileira de Zootecnia, v.41, n.9, p.2064-2069, 2012.

MORENG, R. E. Dietary zinc methionine effect on shell quality of hens drinking saline water. Poultry Science. v. 71. p.1163-1167, 1992.

MUJAHID, A., AKIBA, Y. \& TOYOMIZU, M. Acute heat stress induces oxidative stress and decreases adaptation in young white leghorn cockerels by downregulation of avian uncoupling protein. Poultry Science, 86, 364- 371. 2007.

NASCIMENTO, G. A. J.; COSTA, F. G. P; AMARANTE JUNIOR, V. S.; BARROS, L. R. Efeitos da substituição do milho pela raspa de mandioca na alimentação de frangos de corte, durante as fases de engorda e final. Revista Ciência e Agrotecnologia. 29(1):200-207. 2005.

NASCIMENTO, A.H., GOMES, P.C., ALBINO, L.F.T. et al. Coeficientes de digestibilidade e valores de aminoácidos digestíveis verdadeiros de farinhas de vísceras para aves. In: Conferência Apinco 99, 1999. Campinas. Anais ... Campinas: FACTA. p.27. 1999.

NATIONAL RESEARCH COUNCIL - NRC. Nutrient requirements of poultry. 9.ed. Washington: National Academy Science. p.155, 1994. 
NORTH, M.O., BELL, D.D. Manual de producción avícola. 3.ed. México: Editorial Manual Moderno. p.829, 1993.

NUNES, R. V.; POZZA, P.C.; NUNES, C. G. V.; CAMPESTRINI, E.; KÜHL, R.; ROCHA, L. D.; ET AL. Valores energéticos de subprodutos de origem animal para aves. Revista Brasileira Zootecnia. 34(4):1217-1224. 2005.

NYS, Y. et al. E. Avian eggshell mineralization. Poultry and Avian Biology Reviews, London, v. 10, p. 143-166, 1999.

NYS, Y. Recent developments in layer nutrition for optimizing shell quality. In Proc. 13th . European Symposium on Poultry Nutrition, Blankenberge. p. 4252. 2001.

NYS, Y.; REVY, P.S.; JONDREVILLE, C. Zinc, cuivre et manganese en aviculture: role, disponibilite et risque pour l'environnement. Journées de la recherche avicole, 5., 2003, Tours. Annales... Tours, 2003.

OVESEN J., MOLLER-MADSEN B., THOMSEN J.S., DANSCHER G., MOSEKILDE L. The positive efects of zinc on skeletal strength in growing rats. Bone. v.29. p.565-570, 2001.

PAIK, I. Application of chelated minerals in animalproduction. AsianAustralasian Journal of Animal Sciences, v. 14, p. 191-198, 2001.

PASSOS, D.P. Microminerais orgânicos e vitamina $C$ nas rações de poedeiras semi-pesadas em região de clima quente. 2010. 56f. Dissertação - Universidade Estadual de Montes Claros, Janaúba, MG, 2010.

PEREIRA DA SILVA, E. M.; PEZZATO, L. E. Respostas da tilápia do Nilo (Oreochromis niloticus) à atratividade e palatabilidade de ingredientes utilizados na alimentação de peixes. Revista Brasileira de Zootecnia. 29(5):1273- 1280. 2000.

POLLI S.R. Minerais Orgânicos na alimentação de cães e gatos. Boletim Informativo Nutron Pet. v.4, 2002.

RAMOS, K.C.B.T.; CAMARGO, A.M.; OLIVEIRA, E.C.D. et al. Avaliação da idade da poedeira, da temperatura de armazenamento e do tipo embalagem 
sobre a qualidade de ovos comerciais. Revista Ciências da Vida, v.30, n.2, p.55-66. 2010.

RAVINDRAN, V.; HENDRIKS, W. H.; CAMDEN, B. J.; THOMAS, D. V.; MOREL, P. C. H.; BUTTS, C. A. Amino Acid Digestibility of Meat and Bone Meals for Broiler Chickens. Australian Journal of Agricultural Research, v. 53, n. 11, p. 1257-1264, 2002.

REDDY A.B., Dwived J.N., Ashmead A.D. Mineral chelation generates profit. Misset-World Poultry. v.8. p.13-15, 1992.

RICHARDS, J.D.; ZHAO, J.Z.; HARREL, R.J. et al. Trace mineral nutrition in poultry and swine. Asian-Australasian Journal of Animal Sciences, v.23, n.11, p.1527-1534, 2010.

ROBERTS, J.R. Factors affecting egg shell and internal egg quality. In: 18th Annual ASAIM SE Asian Feed Technology and Nutrition Workshop, Cambodia, May 24-27, 9 p., 2010

ROLAND, D.A. The extent of uncollected eggs due to inadequate shell. Poultry Science, Champaing, v.56(5). p.1517-1521, 1977.

ROSSI L., MIGLACCIO S., CORSI A., MARZIA M., BIANCO P., TETI A., GAMBELLI L., CIANFARANI S., PAOLETTI F., BRANCA F. Reduced growth and skeletal changes in zinc-deficient growing rats are due to impaired growth plate activity and inanition. Journal of Nutrition. v.131. p.1142-1146, 2001.

ROSSI, J. K.; NETO, R. T. MICROMINERAIS NA ALIMENTAÇÃO DE GALINHAS DE POSTURA PARA AVALIAÇÃO DA QUALIDADE DA CASCA DOS OVOS. In: Anais do Congresso Nacional de Medicina Veterinária FAG. 2018.

ROSTAGNO, H. S.; ALBINO, L. F. T.; DONZELE, J. L.; GOMES, P. C.; OLIVEIRA, R. F.; LOPES, D. C.; FERREIRA, A. S.; BARRETO, S. L. T.; EUCLIDES, R. F. Tabelas brasileiras para aves e suínos: Composição de alimentos e exigências nutricionais. 3. ed. Viçosa: UFV. 134-141p. 2011

RUTZ, F., PAN, E., \& XAVIER, G. Efeito de minerais orgânicos sobre o metabolismo e desempenho de aves. Revista Aveworld. 2007a. 
RUTZ. F. et al. Avanços na fisiologia e desempenho reprodutivo de aves domésticas. Revista Brasileira de Reprodução Animal, Pelotas, v. 31, n. 3, p. 307-317, jul./set. 2007b.

SALDANHA, E. S. P. B. et al. Effect of organic mineral supplementation on the egg quality of semi-heavy layers in their second cycle of lay. Brazilian Journal of Poultry Science, v. 11, n. 4, p. 241-247, 2009.

SALIM, H.M.; CHEORUN, J.O.; LEE, B.D. Zinc in broiler feeding and nutrition. Avian Biology Research, v.1(1). p.5-8, 2008.

SANTOS, ANDRÉA LUCIANA DOS. Desempenho, crescimento, qualidade do ovo, composição corporal e características reprodutivas e ósseas de poedeiras submetidas a diferentes programas nutricionais. Tese de Doutorado. Universidade de São Paulo. 2008.

SCHEIDELER, S. E. Trace mineral balance in poultry. In Midwest Poultry Federation Convention, St. Paul, Minnesota, 18-20 March. 2008.

SCHMIDT, M.; GOMES, P. C.; ROSTAGNO, H. S.; et al. Níveis nutricionais de lisina, de metionina + cistina e de treonina digestíveis para galinhas poedeiras no segundo ciclo de produção. Revista Brasileira de Zootecnia, v. 39, n. 5, p. 10991104, 2010.

SCOTT, M.L.; NESHEIN, M.C.; YOUNG, R.J. Nutrition of the chicken. 3.ed. New York: M.L. Scott. p.562, 1982.

SECHINATO A.S., ALBUQUERQUE R., NAKADA S. Efeito da suplementação dietética com micro minerais orgânicos na produção de galinhas poedeiras Brazilian Journal of Veterinary Research and Animal Science, v.43. p.159-166, 2006.

SELL, J.L. \& JEFFREY, M.J. Availability for poults of phosphorus from meat and bone meals of different particle sizes. Poultry Science. 75, 232-239.1996.

SHIRLEY, R. B., PARSONS, C. M. Effect of Ash Content on Protein Quality of 
Meat and Bone Meal. Poultry Science, Champaign, v. 80, n. 5, p. 626-632, 2001.

SILVA, José Humberto Vilar da; MUKAMI, Flordivina; ALBINO, Luiz Fernando Teixeira. Uso de rações à base de aminoácidos digestíveis para poedeiras. Revista Brasileira de Zootecnia, v. 29, n. 5, p. 1446-1451, 2000.

SILVERSIDES, F.G.; SCOTT, T.A. Effect of storage and layer age on quality of eggs from two lines of heans. Poultry Science, v.80, n.1, p.1240-1245, 2001.

SISKE, V.; ZEMAN, L.; KLECKEER, D. The egg shell: A case study im improving quality by altering mineral metabolism. Biotechnology in the feed industry. OF ALLTECH'S, 16TH. In: Annual Symposium. 2000. p. 327.

SOUZA, P.A., FALEIROS, R.R.S., SOUZA, H.B.A. Efeitos sobre a qualidade dos ovos. Avicultura Industrial, São Paulo, v.893. p.24-7, 1984.

STRINGHINI, J. H., JARDIM FILHO, R. M., PEDROSO, A. A., CAFÉ, M. B., CARVALHO, F. B. \& MATOS, M. S. Nutrição no período de pré-postura, pico e pós-pico de poedeiras comerciais. Conferência Apinco de Ciência e Tecnologia Avícola. Fundação Avícola de Ciência e Tecnologia Avícolas Santos, Santos. 2005.

SUN, Q.; GUO, Y.; Li, J.; Zhang, T.; WEN, J. Effects of methionine hydroxy analog chelated $\mathrm{Cu} / \mathrm{Mn} / \mathrm{Zn}$ on laying performance, egg quality, enzyme activity and mineral retention of laying hens. Japan Poultry Science Association, Beijing, c.49, p. 20-25, 2012.

SWIATKIEWICZ, S.; KORELESKI, J. The effect of zinc and manganese source in the diet for laying hens on eggshell and bones quality. Veterinarni Medicina, Praha, v.53, n. 10, p. 555-563, 2008.

TAYLOR, D. M., WOODGATE, S. L. Rendering Practices and Inactivation of Transmissible Spongiform Encephalopathy Agents. Revue Scientifique et Technique, v. 22, n. 1, p. 297-310, 2003.

TRINDADE NETO, M. A.; KOBASHIGAWA, E.; NAMAZU, L. B.; TAKEARA, P.; ARAÚJO, L. F.; ALBUQUERQUE, R. Lisina digestível e zinco orgânico para frangos de corte machos na fase de 22 a 42 dias de idade. Revista Brasileira de 
Zootecnia 39: 2460- 2470. 2011.

UAUY, R., OLIVARES, M., \& GONZALEZ, M. Essentiality of copper in humans. The American journal of clinical nutrition. v.67(5). p.952-959, 1998.

VEIGA, J. D., \& CARDOSO, E. Criação de gado leiteiro na zona bragantina. 2005.

WALDROUP, P.W. \& ADAMS, M.H., 1994. Evaluation of the phosphorus provided by animal proteins in the diet of broiler chickens. J. Appl. Poult. Res. 3, 209-216.

WANG, X.; GOONEWARDENE, Z. The use of MIXED models in the analysis of animal experiments with repeated measures data. Canadian Journal of Animal Science, 84(1), 1-11. 2004.

WANG, X., FOSMIRE G.J., GAY C.V., LEACH JR. R.M. Short-term zinc deficiency inhibits chondrocyte proliferation and induces cell apoptosis in the epiphyseal growth plate of young chickens. Journal of Nutrition. v.132. p.665673, 2002.

WANG, X., PARSONS, C.M. Effect of processing systems on protein quality of feather meals and hog hair meals. Poult. Sci., 76:491-496. 1997.

WEBSTER A.B. Welfare implications of avian osteoporosis. Poultry Science. v.83. p.184-192, 2004.

WHISENHUNT, J.E., MAURICE, D.V. Effect of dietary manganese and phosphorus on the strenght of avian egg shell. Nutrition Report International. v.32(4). p.757-64, 1985.

WHITEHEAD C.C., FLEMING R.H. Osteoporosis in cage layers. Poultry Science. v.79. p.1033-1041, 2000.

XAVIER, G. B.; RUTZ, F.; DIONELLO, N. J. L.; DUARTE; A. D.; GONCALVES, F. M.; ZAUK, N. H. F.; RIBEIRO, C. L. G. Performance of layers fed diets containing organic selenium, zinc and manganese, during a second cycle of production. In Proceedings of the Annual Symposium on Biotechnology in the feed industry, Lexington. p.19. 2004. 
$\mathrm{XIAO}$, J. F. et al. Bioefficacy comparison of organic manganese with inorganic manganese for eggshell quality in Hy-Line Brown laying hens. Poultry Science, v. 94, n. 8 , p. 1871-1878, 2015. 